\title{
ISSN:2178-8839
}

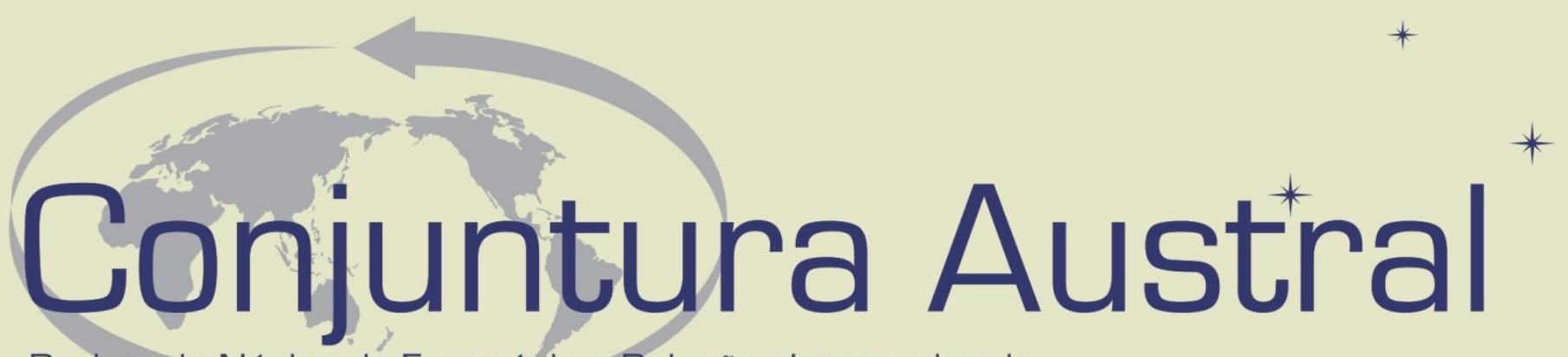

Revista do Núcleo de Estratégia e Relações Internacionais

Programa de Pós-Graduação em Estudos Estratégicos Internacionais/UFRGS

A CRISE NA SÍRIA (2011-2013): UMA ANÁLISE MULTIFATORIAL

A IRMANDADE MUÇULMANA NA SÍRIA

A POSIÇÃO BRASILEIRA FRENTE AO CONFLITO NA SÍRIA (2011-2013)

LAS MONARQUÍAS DEL CONSEJO DE COOPERACIÓN DEL GOLFO (CCG) Y EL

CAMBIO CLIMÁTICO

UNIÃO AFRICANA (U.A): DESAFIOS E OPORTUNIDADES DO BLOCO

A IMIGRAÇÃO HAITIANA PARA O BRASIL: CAUSAS E DESAFIOS

A V CUPULA DO BRICS (DURBAN, 2013): COALIZÃO OU ARRANJO COOPERATIVO?

RESENHA DO LIVRO "MILITARY POWER: EXPLAINING VICTORY AND DEFEAT IN MODERN BATTLE"
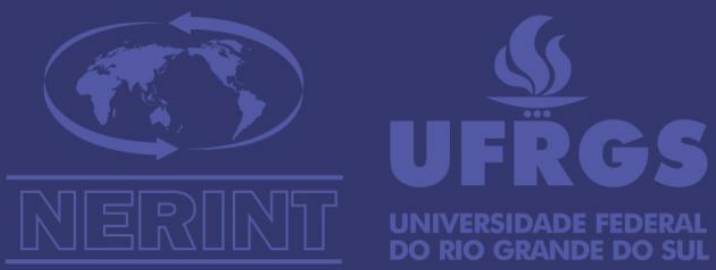


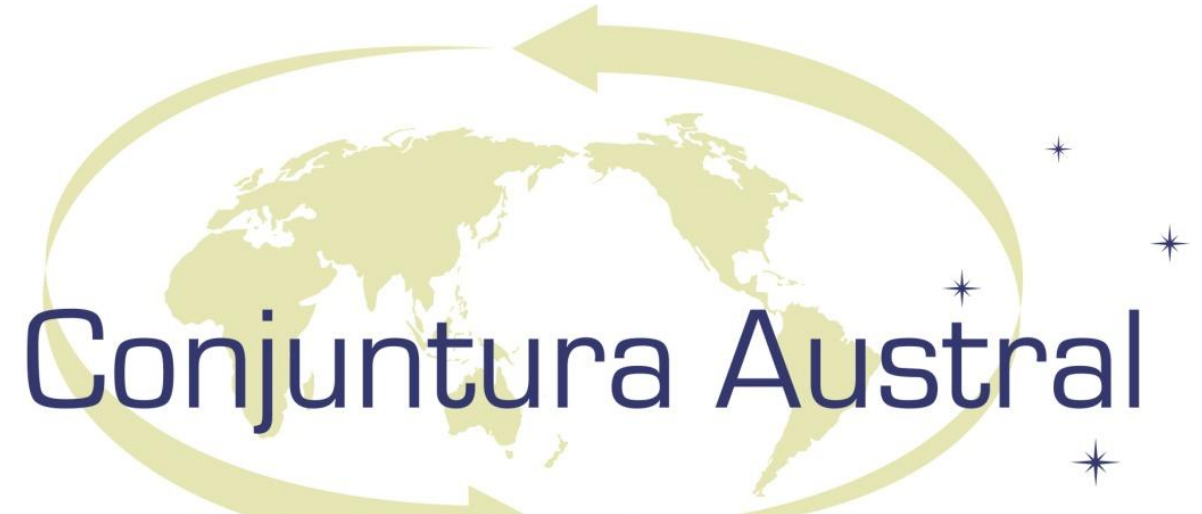




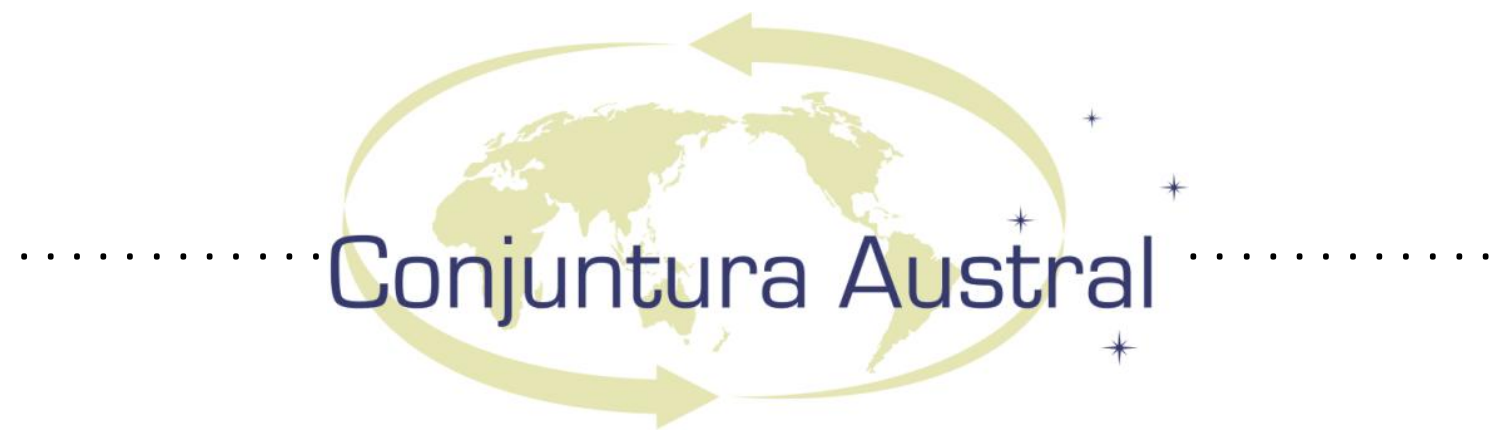

\section{FOCO E ESCOPO}

CONJUNTURA AUSTRAL é uma publicação Bimestral, em formato digital, do Núcleo de Estratégia e Relacões Internacionais da UFRGS (NERINT), que publica trabalhos de relações internacionais com foco nos países que integram o Hemisfério Sul. Nesse sentido, tem como área geográfica de abrangência as relações internacionais da Africa, Ásia e América Latina, na perspectiva dos grandes temas da agenda de segurança, diplomacia e desenvolvimento.

A revista publica contribuições na forma de análises de conjuntura, artigos científicos e resenhas bibliográficas, cuja temática se situe na grande área de Estratégia e Relações Internacionais, com especial interesse nos temas relacionados aos países do hemisfério Sul político e suas estratégias de segurança e desenvolvimento.

Missão

Promover o debate e a reflexão sobre a conjuntura internacional, com ênfase nos processos de interesse imediato dos países em desenvolvimento.

\section{FOCUS AND SCOPE}

CONJUNTURA AUSTRAL is a bimonthly publication of NERINT (Center for International Relations and Strategic Studies), in digital format, that publishes international relations papers focusing on the countries that integrate the Southern Hemisphere. In that sense, its geographic coverage area comprises Africa, Asia and Latin America, in the perspective of great subjects of the security, diplomacy and development agendas.

The journal publishes contributions in the form of conjuncture analyses, articles and book reviews, about themes that lie in the vas area of Strategy and International Relations, with special interest in issues related to countries situated in the political South and their security and development strategies.

Mission

Promoting consideration and academic debate on the international conjuncture, with emphasis on processes of immediate interest in the developing countries.

\section{CONSELHO EDITORIAL/ Editorial Board}

Adam Habib (University of Johannesburg, África do Sul)

Amado Luiz Cervo (Universidade de Brasília, Brasil)

Antonio Jorge Ramalho (Universidade de Brasília, Brasil)

Bertrand Badie (Sciences Po, França)

Boris F. Martynov (Academia de Ciências da Rússia/ Russian Academy of Sciences)

Carlos Arturi (Universidade Federal do Rio Grande do Sul, Brasil)

Flávio Sombra Saraiva (Universidade de Brasília, Brasil)

Gladys Lechini (Universidad Nacional de Rosário, Argentina)

Immanuel Wallerstein (Yale University, Estados Unidos)

Marcos Costa Lima (Universidade Federal de Pernambuco, Brasil)

Mehdi Parvizi Amineh (University of Amsterdam, Holanda)

Samuel Pinheiro Guimarães (Alto Representante-Geral do Mercosul/ High General Representative of the Mercosur)

Shiguenoli Miyamoto (Universidade Estadual de Campinas, Brasil)

Willians Gonçalves (Universidade Federal Fluminense / Universidade do Estado do Rio de Janeiro, Brasil)

\section{COMITÊ EDITORIAL/ Editorial Committee}

André Luiz Reis da Silva (Universidade Federal do Rio Grande do Sul, Brasil) - Editor

Paulo Gilberto Fagundes Vizentini (Universidade Federal do Rio Grande do Sul, Brasil) - Editor Adjunto

André Moreira Cunha (Universidade Federal do Rio Grande do Sul, Brasil) - Membro do Conselho

Marco Aurélio Chaves Cepik (Universidade Federal do Rio Grande do Sul, Brasil) - Membro do Conselho

Eduardo Ernesto Filippi (Universidade Federal do Rio Grande do Sul, Brasil) - Membro do Conselho

Luiz Augusto Faria (Universidade Federal do Rio Grande do Sul, Brasil) - Membro do Conselho

José Miguel Quedi Martins (Universidade Federal do Rio Grande do Sul, Brasil) - Membro do Conselho

\section{Assistentes de Edição / Edition Assistants}

Roberta Preussler dos Santos (Universidade Federal do Rio Grande do Sul, Brasil)

\section{CONTATO / Contact:}

Universidade Federal do Rio Grande do Sul - Faculdade de Ciências Econômicas

Programa de Pós-Graduação em Estudos Estratégicos Internacionais

Av. João Pessoa, 52 sala 33A - $3^{\circ}$ andar - CEP 90040-000 - Centro - Porto Alegre/RS - Brasil

Tel: +55 51 3308-3963 ou +55 $513308-7150$ Fax: +55 $513308-3963$

e-mails: ppgeei@ufrgs.br, reisdasilva@hotmail.com, nerint@ufrgs.br ou robertapreussler@gmail.com. 


\section{…...... Conjuntura Austral ….......}

Volume 4, Número 20 (Out. Nov. 2013)

EDITORIAL

André Luiz Reis da Silva

\section{ANÁLISE DE CONJUNTURA}

A Crise na Síria (2011-2013): Uma Análise Multifatorial.

6

Danny Zahreddine

A Irmandade Muçulmana na Síria

Guilherme Di Lorenzo Pires

A posição Brasileira frente ao conflito na Síria (2011-2013).

Bruna Figueiredo Riediger

\section{ARTIGOS}

Las monarquías del Consejo de Cooperación del Golfo (CCG) y el cambio climático

Ornela Fabani

União Africana (U.A): desafios e oportunidades do bloco

69

Jacqueline A. H Haffner, Genivone Etmy Sequeira Viana

A Imigração haitiana para o Brasil: causas e desafios.

95

Isaias Albertin de Moraes, Carlos Alberto Alencar de Andrade, Beatriz Rodrigues Bessa Mattos

A V Cúpula do BRICS (Durban, 2013): Coalizão ou arranjo cooperativo?

Leonardo Ramos, Pedro Henrique Schneider Parreiras

\section{LEITURA}

Resenha do livro "Military Power: Explaining Victory and Defeat in Modern Battle" de Stephen M. Biddle.

Tamires Pereira dos Santos 


\section{EDITORAL}

\section{Editor's Note}

É com grande satisfação que lançamos esta vigésima edição da revista CONJUNTURA AUSTRAL, dedicada à análise das Relações Internacionais contemporâneas. Em agosto deste ano, a revista completou três anos de atividades, com várias conquistas realizadas. Neste período, a revista se consolidou e está contribuindo para o desenvolvimento da área de Relações Internacionais, divulgando a pesquisa e a reflexão científica sobre os países em desenvolvimento.

Para este número, organizamos um dossiê sobre a "Crise na Síria", um tema candente no cenário internacional. E este é um dos propósitos da revista: ser um elemento articulador de reflexão científica sobre o tempo presente, sobre a conjuntura internacional, oferecendo explicações sobre processos em andamento. Sabemos que escrever sobre o tempo presente tem seus "perigos", ainda mais com a guerra de (des) informação que gira em torno da questão síria, apimentada por interpretações pouco científicas. Contra estas tendências, três analistas buscam, neste número, lançar algumas explicações sobre o que está em jogo nesta crise. Assim, Danny Zahreddine, Guilherme Di Lorenzo Pires, Bruna Figueiredo Riediger buscam descortinar algumas facetas da crise.

Já na seção Pesquisa, publicamos quatro artigos. No artigo "Las monarquías del Consejo de Cooperación del Golfo (CCG) y el cambio climático", Ornela Fabani, procura analisar o posicionamento das monarquias do Conselho do Cooperação do Golfo sobre a discussão de mudança climática que, segundo a autora, vem passando de uma posição obstrucionista para uma posição mais moderada nos fóruns ambientais internacionais. O continente africano é tema do artigo de Jacqueline Haffner e Genivone Etmy Sequeira Viana, que, com o título "União Africana (U.A): desafios e oportunidades do bloco", analisam como a sucessora da OUA se traduz numa vontade 


\section{Conjuntura Austral}

política dos dirigentes africanos na busca por uma maior e melhor inserção do continente africano no panorama mundial.

Enquanto isso, no artigo “A Imigração haitiana para o Brasil: causas e desafios”, Isaias Albertin de Moraes, Carlos Alberto de Andrade, Beatriz Bessa Mattos procuram analisar a recente imigração haitiana para o Brasil, bem como o governo têm lidado com esta situação. O tema dos países emergentes é uma das linhas fundamentais da nossa publicação. Desta vez, Leonardo Ramos e Pedro Henrique Schneider Parreiras analisam, no artigo “A V Cúpula do BRICS (Durban, 2013): Coalizão ou arranjo cooperativo?", como a Cúpula de Durban indica que o grupo caminha rumo a um novo patamar de cooperação e institucionalização, sendo o banco de desenvolvimento do BRICS e o fundo comum de reserva elementos que apontariam nesta direção. Para finalizar esta edição, Tamiris Pereira dos Santos resenha o livro "Military Power: Explaining Victory and Defeat in Modern Battle" de Stephen Biddle, lançado pela Princeton University Press.

Mais uma vez, em nome da comissão editorial, gostaríamos de agradecer à equipe técnica, aos autores, pareceristas e aos leitores, que tem prestigiado nosso trabalho. Agradecemos os colegas do Fórum de Editores da ABRI, pelo apoio mútuo, à Pró-Reitoria de Pesquisa da UFRGS, pelo incentivo institucional.

Neste vigésimo número, é devido um agradecimento especial ao nosso grupo de mais de quarenta pareceristas, cujo trabalho anônimo e voluntário é absolutamente essencial para a manutenção da qualidade de um periódico científico.

Prof. André Luiz Reis da Silva

Editor 


\title{
Conjuntura Austral
}

\section{A CRISE NA SÍRIA (2011-2013): UMA ANÁLISE MULTIFATORIAL}

\section{Crisis in Syria (2011-2013): A Multifactorial Analysis}

\author{
Danny Zahreddine ${ }^{1}$
}

Desde o dia 15 de março de 2011, após manifestações pacíficas da população síria, que protestavam contra o governo do presidente Bashar al Assad, que o país vivencia uma das crises mais violentas de sua história recente. A reivindicação de parcela da população por reformas constitucionais que favorecessem uma maior abertura política do país recebeu como resposta um sonoro não, que ao passar dos meses se transformou em uma guerra civil. O objetivo deste artigo é analisar a crise vivenciada pela Síria, na esteira da "Primavera Árabe", evidenciando os seguintes aspectos:o fator multiconfessional presente no conflito, a relevância do equilíbrio de poder regional, bem como os aspectos que geraram o impasse mais intenso dos últimos anos entre Estados Unidos da América e a Federação Russa.

Os estudos sobre região nas Relações Internacionais ganharam proeminência após o fim da guerra fria, em função do término da polarização do Sistema Internacional em dois campos de força. O nível sistêmico, caracterizado por ser mais fechado (perspectiva estruturalista) e menos exposto a atores externos, limitou a compreensão de determinadas questões, enquanto o nível regional, por sua natureza mais aberta, favoreceu a observação de uma série de outros fenômenos, até então, não tratados pelo nível sistêmico(LAKE \& MORGAN, 1997).Para abordar a questãoproposta,a Escola Inglesa se apresenta como uma boa lente teórica. Os níveis de análise doméstico,

\footnotetext{
${ }^{1}$ Professor Dr. do Departamento de Relações Internacionais da PUC Minas (Graduação e Pós-graduação) Líder do Grupo de Estudos Oriente Médio e Magreb (GEOMM). E-mail: danny@ pucminas.br
} 


\section{Conjuntura Austral}

regional e sistêmico (BUZAN, 1998) serão essenciais para evidenciar a multidimensionalidade da questão Síria.

Desta forma,após uma breve contextualização histórica sobre a Síria, serão destacados aspectosdos setores político, societal e militar (BUZAN, 1998) dos níveis de análise apresentados anteriormente.Estas múltiplas dimensões do conflito podem ser delimitadas em três camadas principais: a primeira diz respeito ao Estado-nação, a segunda está ligada às forças regionais e a terceira às grandes potências mundiais.

\section{Da “Grande Síria” à fundação da República da Síria}

A História da Síria está intimamente ligada aos processos de expansão de grandes civilizações antigas e das potências modernas. Devido à sua localização no mediterrâneo oriental, e em função da presença de grandes rios com terras agricultáveis, a posição geográfica da Síria foi um ponto importante para a conexão entre as potências ocidentais e seus domínios na Ásia.

O Império Romano utilizou dos Oásis de Palmira (Tadmur) para conectar suas rotas de comércio entre o Crescente Fértil e a Ásia Central. A batalha por Damasco, na Revolta Árabe de 1916 foi crucial para desarticular o já combalido Império Turco Otomano no Oriente Médio. A presença francesa pós Primeira Grande Guerra, garantiu a manutenção de minorias cristãs na região, que favoreceu enormemente os interesses da potência mandatária.

De maneira genérica, a ideia da "Grande Síria" foi resgatada no período do mandato francês da Síria e do Líbano (1920), após o fím da Primeira Grande Guerra. As reminiscências da presença Assíria na região reforçou o desejo do estabelecimento de uma "Grande Síria” que se estenderia desde os Montes Zagros (fronteira entre Iraque e Irã), até as margens do Mediterrâneo Oriental, ocupando basicamente o Crescente Fértil. Esta tese inclusive alimentou a ideia da criação de um grande Estado Árabe que pudesse agregar todo este território. Alguns partidos nacionalistas como o Partido Nacionalista Sírio, fundado em 1932, utilizarão esta tese para justificar a manutenção de uma "Grande Síria", que deveria alcançar até a Península do Sinai. A unidade política deste Estado residiria não somente no aspecto linguístico e religioso, como no caso do 


\section{Conjuntura Austral}

movimento arabista, mas também na "longa gênese histórica que tem seus fundamentos e sua zona de extensão 'natural' na antiga Assíria” (MASSOULIÉ, 1996, p. 39).

A revolta Árabe de 1916, liderada por Husseyn, Xerife de Meca, da família Hachemita, buscava a criação de um grande Estado Árabe, que se estenderia do Iraque ao Líbano, e da Península Arábica até a fronteira norte com a Turquia. O apoio dado aos Ingleses na Primeira Grande Guerra, com o intuito de expulsar as forças turcas da região, teria como objetivo a criação deste grande Estado Árabe. Porém, em função dos acordos secretos de Sykes-Picot, entre Reino Unido e França, a região se tornou uma zona de influência de britânicos e franceses. Com o fim da Revolta Árabe contra os turcos e o término da Primeira Grande Guerra, a promessa feita a Husseyn e a seus filhos pelos britânicos de criação de um "Estado Árabe" unificado não foi cumprida. Os franceses receberam da Liga das Nações, em 1920, o Mandato dos atuais Líbano e Síria, enquanto os britânicos se tornaram mandatários da Palestina, Iraque e Transjordânia.

A "Grande Síria" do mandato francês, neste momento histórico, era formada pelos atuais Líbano, Síria e a província Turca de Hatay. É importante salientar que tanto o Líbano quanto a Síria são sociedades marcadas pela presença de minorias étnicas e religiosas importantes, sendo este um elemento fundamental para o entendimento dos problemas que a região vivenciaráno início século XXI. Os franceses utilizaram da estratégia "dividir para governar" com o intuito de desarticular movimentos nacionalistas mais robustos que pudessem por em risco os projetos da potência mandatária.

Desta forma, em 1921, a França elaborou um censo demográfico da região, para dividir as terras sob seu controle, o que poderia ser o prelúdio da fragmentação futura do território em pequenas repúblicas. Enquanto os britânicos privilegiaram a criação de Monarquias Constitucionais sob suas possessões, os franceses preferiram a constituição de Repúblicas (CLEVELAND, 2009).

O Resultado do Censo Francês levou à criação de seis províncias na "Grande Síria", onde o aspecto confessional seria central para a criação dos futuros "Estados". 


\section{Conjuntura Austral}

Seriam eles: o Estado de Alepo, o Estado de Damasco, o Estado de JabalDruze ${ }^{2}$, o Estado Alauita ${ }^{3}$, a Província de Alexandreta (Hatay) e o "Grande Líbano". Cada um destes Estados estaria sob o controle de uma elite confessional, tutelada pela França.

Este elemento confessional/étnico pode ser observado no desenho dos limites territoriais da Síria sob Mandato francês: duas províncias eram de maioria Sunita (Estado de Alepo e Estado de Damasco), uma de maioria Drusa (Estado de JabalDruze), uma de maioria cristã (Grande Líbano ${ }^{4}$ ), um Estado de maioria Alauita (Estado Alauita) e uma província autônoma de maioria Turca (Sanjak Alexandreta)(CLEVELAND, 2009).

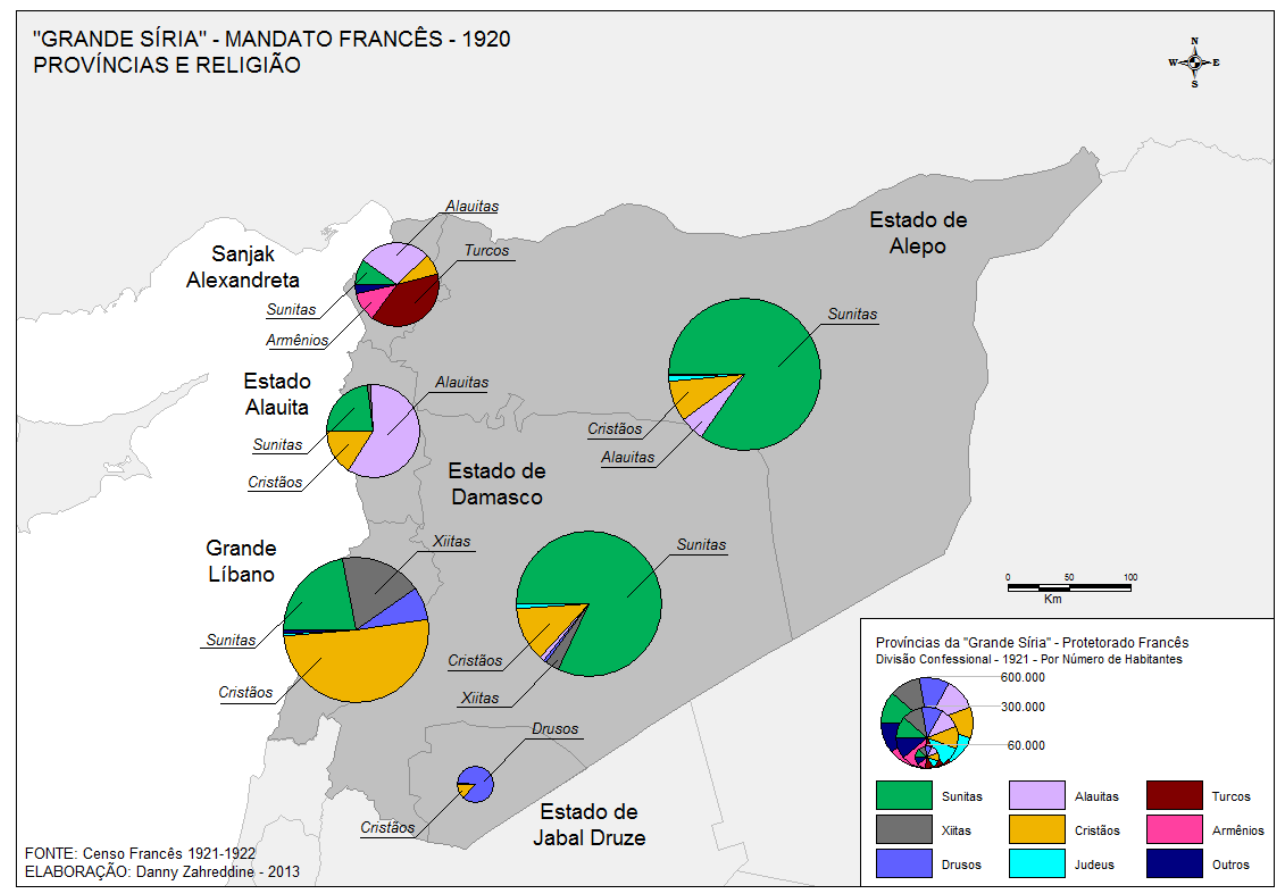

\footnotetext{
${ }^{2}$ JabalDruze é uma transliteração do árabe que significa montanha Drusa, ou montanha dos Drusos. Esta minoria religiosa ocupou áreas montanhosas do Líbano e da Síria, em função das perseguições que sofreu de outras ramificações do Islã, semelhante ao caso dos Alauitas na Síria e dos Cristãos maronitas no Líbano, que também se caracterizaram por ocupar áreas montanhosas.

${ }^{3}$ Os Alauitas são uma minoria religiosa muçulmana, ligada ao ramo xiita, com forte devoção à Ali, genro e primo do Profeta Maomé, considerado pelos xiitas como o primeiro Califa Rashidun, ou, "O Bem Guiado" (SEDDON, 2004).

${ }^{4} \mathrm{O}$ termo Grande Líbano foi cunhado em função da anexação de parte do território Sírio no período do Mandato Francês. O pequeno Líbano tinha como limite oriental o Monte Líbano. Com o Mandato Francês este limite se estendeu até a cordilheira do Antilíbano, englobando todo o Vale do Bekka. A porção sul e norte também foi estendida, integrando as cidades de Saida e Tiro ao sul, e Trípoli ao norte (CLEVELAND, 2009). Esta configuração territorial será a fronteira oficial da República do Líbano, formalmente reconhecida pelas Nações Unidas em 1946.
} 


\section{Conjuntura Austral}

Já em 1921 eram evidentes os desdobramentos que a fragmentação territorial, marcada por limites étnico-religiosos,traria para a futura Síria. Em um primeiro momento, os franceses tentaram propiciar às lideranças sunitas urbanas mais espaço político, devido seu caráter moderado. Porém, o receio do fortalecimento dos sunitas na Síria, em detrimento das demais minorias (principalmente cristãs) e da presença francesa, levou à divisão da área de predominância sunita em duas províncias distintas (Alepo e Damasco).

Em resposta a esta tentativa de partilha da "Grande Síria", uma revolta árabe teve início em 1925, no JabalDruze. Liderada pelo DrusoSultanalAtrach, esta revolta visava deter o processo de fragmentação do território árabe, com o intuito de reforçar o caráter anti-imperialista e pró-árabedaquele movimento(CLEVELAND, 2009). O principal objetivo da revolta era criar as condições para expulsar os franceses da Síria, bem como estabelecer um grande Estado Árabe. A revolta foi controlada em 1927, e vencida pelos franceses. Porém, esta ação inviabilizou o processo mais amplo de fragmentação da "Grande Síria" francesa, e permitiu a manutenção de um núcleo um pouco mais sólido para a futura República da Síria.

Do território inicial controlado pelos franceses, na Síria e no Líbano, os "Estados" de Damasco e de Alepo foram incorporados à administração francesa da Síria em uma única unidade em 1924. Posteriormente, em 1936, o "Estado" de JabalDruze e o "Estado"Alauita também foram anexados à Síria, diminuindo o caráter autônomo destes territórios. Já Sanjak/Alexandretase tornouindependente em 1938 e foi anexada pelos turcos em 1939, tornando-se a província turca de Hatay. Já o "Grande Líbano" proclamou sua independência em 1943, sendo oficialmente reconhecida pelas Nações Unidas em 1946 como a República do Líbano. 


\section{Conjuntura Austral}

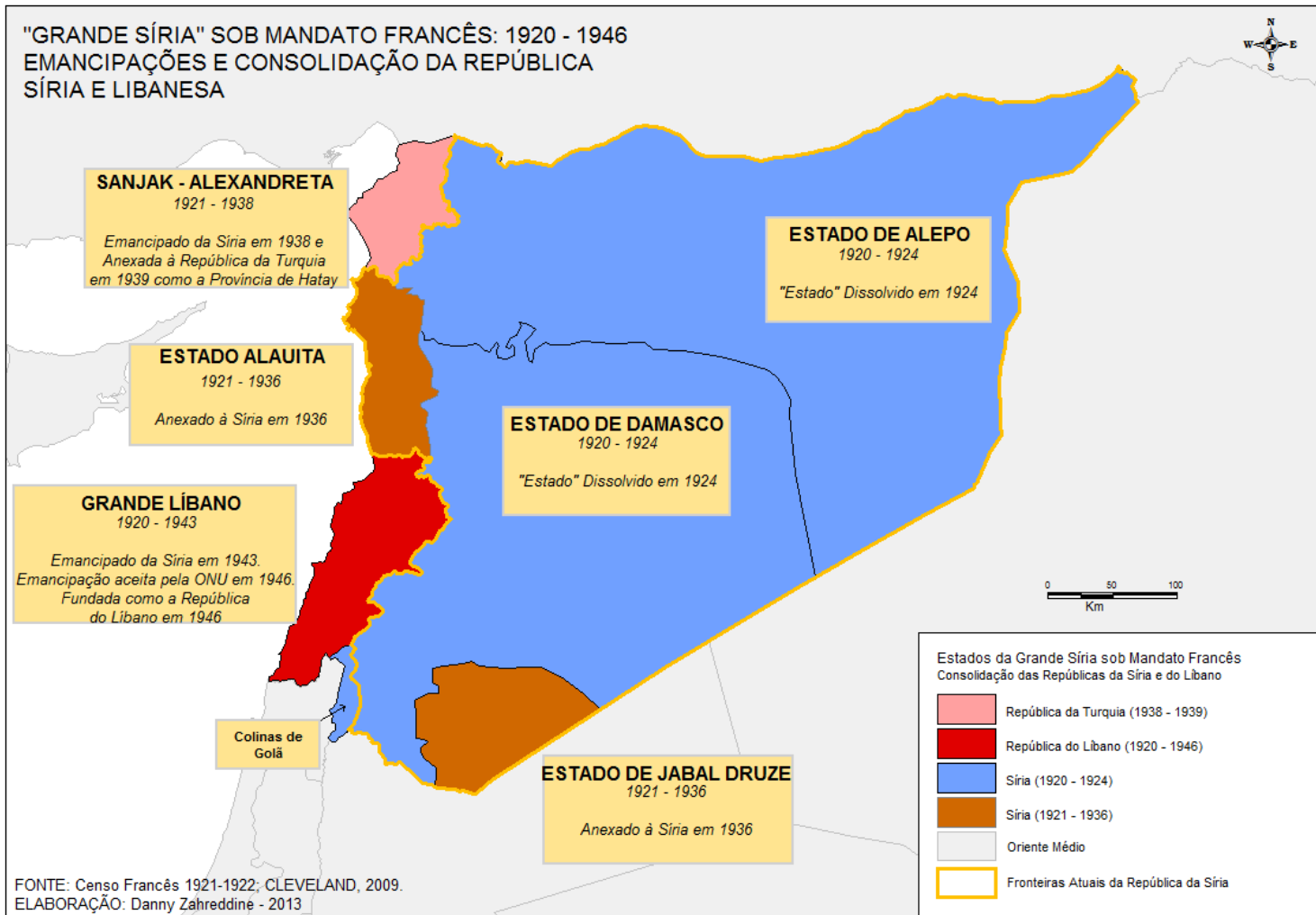

A Síria também formalizou sua independência em 1946, mantendo uma maioria formada por muçulmanos sunitas (aproximadamente $70 \%$ da população) e por uma série de minorias importantes e geograficamente identificáveis, como os cristãos, alauitas, drusos e outros.

\section{A República da Síria}

Desde sua independência, em 17 de abril de 1946, a história politica da Síria foi marcada por eventos importantes. No âmbito local, a disputa de poder pelo controle do país gerou uma série de golpes e contra golpes até 1971. De 1946 a 1958 a República da Síria foi governada por dez presidentes. Nasser foi o presidente da República Árabe Unida (RAU), durante a existência desta, de 1958 a 1961, resultado da união entre Egito e Síria. Com o fim da RAU em 1961 o partido Baath Sírio teve papel fundamental para a transformação política da Síria, sendo que em 1963 efetivamente toma o poder no país, e em 1964 muda o nome do Estado para República Popular da Síria, reforçando o caráter Pan-arabista e socialista daqueleEstado (MOUBAYED, 1996). 


\section{Conjuntura Austral}

De 1961 a 1970 o país também sofre com os golpes militares, e sete presidentes ocuparam o cargo mais alto do executivo Sírio. Por fim, em 22 de fevereiro de 1971, o oficial da aeronáutica, com fortes laços com a União Soviética, Hafez al Assad, toma o poder por meio de outro golpe militar. Porém, ao contrário dos antecessores, consegue manter-se no poder até 10 de junho de 2000, ano de sua morte. A transição política de seu governo foi feita através de seu filho, Bashar al Assad, naquele mesmo ano, permanecendo no poder até os dias de hoje (2013).

Hafez al Assad era de uma família modesta e fazia parte de uma minoria religiosa na Síria, os Alauitas. Este caráter minoritário sempre esteve presente no seu governo, pois constantemente buscava formas de governabilidade que permitisse a ascensão socioeconômica e política de sua minoria (os alauitas), bem como dos cristãos e drusos, em detrimento da maioria sunita.

Este breve retrato das sucessões presidenciais na Síria revela a complexidade da composição política no país, sendo que, somente a partir de 1971 o presidente Hafez al Assad cria as condições para controlar mais firmemente as forças armadas e os principais grupos político-confessionais do país. A maior presença das minorias nas Forças Armadas, bem como em cargos políticos e na burocracia síria, criou um grupo altamente fiel ao presidente e à sua família, o que pode ser visto claramente na guerra civil iniciada em 2011.

Após a morte de Hafez al Assad, em 10 de junho de 2000, um Referendo popular foi feito para legitimar a condução de seu filho, Bashar al Assad ao poder, com apenas 34 anos de idade. Para isto, a própria constituição síria teve de ser alterada para diminuir a idade mínima aceita para ocupar o cargo de presidente. Bashar manteve suas alianças locais como no período de seu pai, calcado principalmente na força das alianças com as minorias. Em um primeiro momento, parecia que o novo presidente poderia trazer mudanças reais para o regime Sírio, em função de sua formação europeia (oftalmologista formado na Inglaterra) e por sua jovialidade. Algumas pequenas transformações foram percebidas nos primeiros anos, como maior acesso à informação (por meio da internet) e tentativas do presidente em retirar a Síria de seu forte isolamento político. Porém, observou-se que as forças políticas que sustentavam seu 


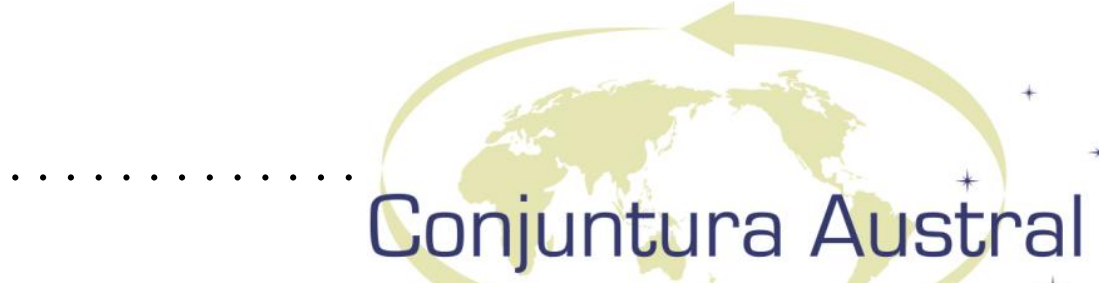

governo não permitiram uma mudança mais profunda do Modus operandi do regime, mantendo os mesmos instrumentos de ação do período anterior.

\section{O primeiro nível de análise - Da Política Doméstica.}

Neste primeiro nível de análise, fica claro a complexidade da sociedade Síria, marcada por uma diversidade étnica e religiosa. Em 2000, de acordo com Yzadi (2000), o grupo religioso predominante eram os Sunitas, com $68,4 \%$ da população, sendo os Alauitas o segundo maior grupo, com 11,3\%, seguidos pelos Cristãos com 11,2\%, os Drusos com 3,2\% e os Xiitas com 3,2\%. É importante destacar que esta sociedade também é caracterizada por minorias étnicas, como os curdos e armênios, que possuem um papel importante no país. Este quadro se torna ainda mais complexo em virtude do conflito palestino israelense, pois desde 1948 (Independência do Estado de Israel) o país tem recebido um alto fluxo de refugiados palestinos.

A busca por adequar as aspirações de todas estas comunidades é algo difícil, em função de características próprias da sociedade árabe, muito ligada aos laços familiares e clânicos, reforçados por princípios de mérito e honradez (HOURANI, 1994). Desta forma, as disputas entre as diversas comunidades são marcadas por rígidos códigos de comportamento, pautados no respeito às famílias e clãs. Na ausência de instituições nacionais capazes de mediar as relações de poder entre as comunidades, o papel das instituições primárias, como a religião e a família (BUZAN, 2004) se mostram primordiais para a manutenção da ordem no Estado. Mesmo o governo Sírio sendo laico, sua sociedade não é secular, e muito das contradições que podem ser encontradas entre a relação do governo com sua sociedade é fruto deste descompasso (SANTOS FILHO, 2013).

A Síria se manteve livre dos processos de fragmentação nos últimos 42 anos devido a duas razões principais: 1) a criação de um exército muito fiel ao seu presidente, e 2) pela utilização da violência para inibir qualquer perturbação da ordem pública, seja pelo uso das forças armadasou das forças de segurança do Estado (serviço de inteligência). 


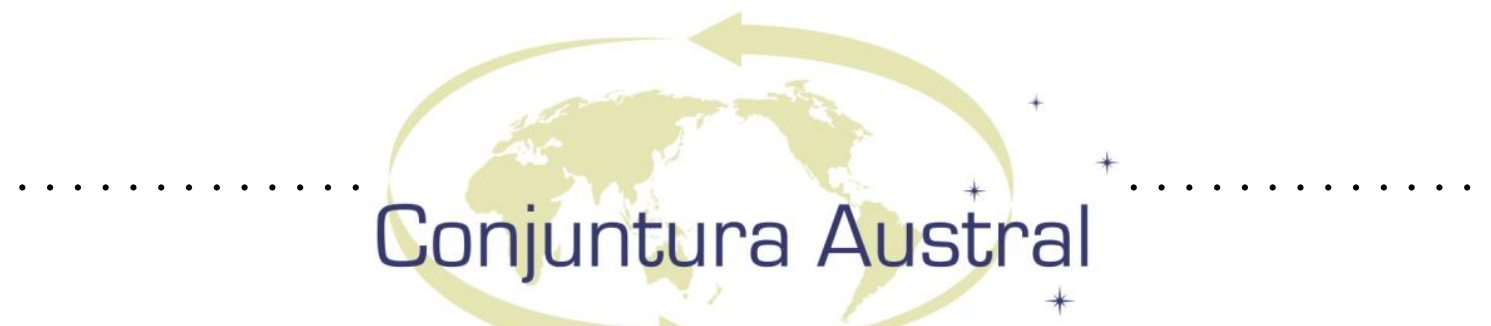

Um exemplo da utilização da violência como instrumento para arrefecer movimentos políticos foi o massacre ocorrido em 1982, na cidade Hama. Com o intuito de encerrar uma disputa com a Irmandade Muçulmana Síria, o presidente Hafez al Assad ordenou o cerco e destruição da resistência islâmica que se encontrava na cidade. Ao final de 27 dias de cerco, o governo havia acabado com a revolta, deixando um saldo de 10.000 mortos $^{5}$ (SEDDON, 2004). Esta resposta do governo sírio foi responsável por desencorajar a maioria dos movimentos contrários ao seu governo até a morte do presidente Hafez al Assad, em 2000.

\section{O Segundo Nível de Análise - O Contexto Regional}

A existência de relevantes forças regionais pode ser identificada ao longo da história do Oriente Médio. Os persas tiveram um papel de destaque, seja se contrapondo aos gregos, ou posteriormente, na era islâmica, se rivalizando com os sunitas, devido ao rompimento entre os descendentes do Profeta Maomé e os seguidores de Abu Bakr. Já o Império Turco Otomano controlou durante séculos a ordem regional, agregando em sua zona de controle os povos mais distintos, desde búlgaros, sérvios e gregos, até os árabes da mesopotâmia, do Crescente Fértil, da Península Arábica e do Magreb. No alvorecer do século XX, novos atores regionais surgirão, fruto do processo de descolonização.

Após a Primeira Grande Guerra, no prelúdio das independências tardias, algumas unidades políticas já davam sinal de seu protagonismo futuro, sendo que a busca por influenciar de maneira mais decisiva a região sempre foi um aspecto dos Reinos ou Repúblicas nascentes do Oriente Médio. É Neste contexto que a República da Turquia, o Reino da Arábia Saudita, a República do Egito ea República Islâmica do Irã surgirão como atores centrais das disputas regionais. Ocupando um segundo círculo de poder, Iraque ${ }^{6}$, Israel e Síria também desempenharão um papel relevante na condução das crises regionais.

\footnotetext{
${ }^{5}$ Algumas estimativas oscilam entre 10.000 e 40.000 mortos.

${ }^{6}$ Até o fim da Guerra Irã-Iraque, o Iraque era considerado uma das forças árabes mais emblemáticas do Oriente Médio. Com o desgaste propiciado pela guerra com o Irã, e a posterior invasão internacional promovida na Primeira Guerra do Golfo, o Iraque deixa de ser um ator central nas relações inter-árabes e no conflito Palestino Israelense.
} 


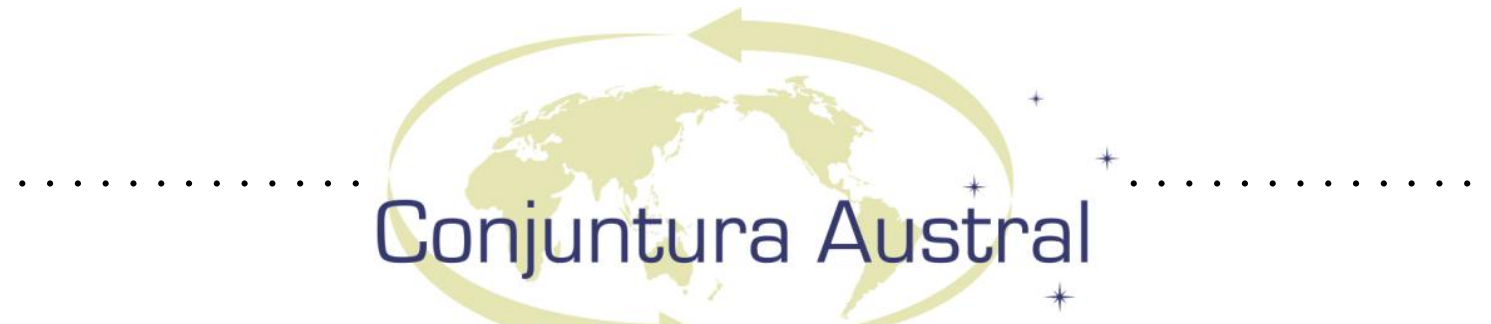

O conflito interno vivenciado pela Síria, nos desdobramentos da "Primavera árabe", revela a importância destes atores regionais, sendo que dentre as várias razões que levaram ao impasse vivido pelas forças do governo e da oposição síria, podem ser creditadas ao embate entre esses mesmos atores. Esta disputa entre potências emergentes, ou integrantes do grupo denominado "Next Eleven"” (SILVA, 2013), aprofunda a crise vivenciada pelo país árabe, e aumenta a intensidade dos confrontos.

Na Guerra Civil Síria, iniciada em 2011, fica evidente a disputa de dois atores regionais pela vitória no teatro de operações. Arábia Saudita e Irã, antagonistas conhecidos de muitos anos, reforçam suas oposições ao apoiarem claramente os lados envolvidos no impasse doméstico Sírio. A Arábia Saudita, responsável por uma agenda de ampliação ${ }^{8}$ de sua presença em todo o Oriente Médio, seja por meio de seus petrodólares, ou pelo financiamento de madrassas $^{9} \mathrm{e}$ fundações que reforcem o wahabismo na região, se contrapõe violentamente aos objetivos iranianos. A aliança entre Estados Unidos da América e Arábia Saudita, de caráter pró-ocidente e conservadora, se opõe à presença iraniana na Síria, que por sua vez, defende a expansão de seu modelo de regime islâmico e sua posição anti-imperialista e anti-estadunidense.

O Egito, importante ator regional, que durante a década de 1950 e 1960 transformou o equilíbrio de poder na região com o Pan-arabismo, mudou profundamente seu direcionamento político após a Guerra dos Seis dias e a Guerra do YonKippur, se preocupando mais com sua agenda doméstica em detrimento da liderança regional. Em função disto, o papel desempenhado pelo Egito na crise Síria é bem menos relevante. É importante destacar também que a "Revolução de Lotus" gerou grande instabilidade naquele país, o que dificilmente permitiria uma ação mais assertiva deste ator com relação ao conflito na Síria.

\footnotetext{
7 "Estes países emergentes são conhecidos como "pequenos BRICS" ou "Next Eleven" (Egito, Indonésia, Irã, México, Nigéria, Paquistão, Filipinas, Coréia do Sul, Turquia, Vietnã e Bangladesh) a partir da classificação do banco Goldman Sachs. Considerando sua população, crescimento do PIB e capacidade de modernização, há expectativa de uma presença cada vez maior destes países no cenário internacional" (SILVA, 2013, p. 3).

${ }^{8}$ Movimento ampliado após os atentados de 11 de setembro nos Estados Unidos e após a crise financeira de 2008 naquele mesmo país.

${ }^{9}$ Escolas destinadas ao ensino religioso islâmico.
} 


\section{Conjuntura Austral}

O que se percebe no embate entre governo sírio e oposição é o forte apoio iraniano ao governo sírio, com envio de material bélico e efetivo militar, enquanto o governo saudita envia dinheiro e armas à oposição, na tentativa de derrubar o governo. A disputa por esta zona de influência deixa transparecer também o embate xiismo (Irã) versus sunismo (Arábia Saudita), o que confere ao conflito ainda mais violência, em função de seu teor confessional.

Porém, tais potências regionais mantêm alianças com outros atores do Oriente Médio, o que polariza ainda mais o conflito, e gera um Spillover da violência e da Instabilidaderegional. A Arábia Saudita potencializaa força de sua atuaçãoa partir das alianças com os países do golfo Pérsico (Conselho de Cooperação do Golfo) e Egito (após a queda do presidente Mohamed Morsi). Enquanto o Irã reforça suas bases com o apoio do Grupo Libanês Hizballah.

Além destes atores, Israel e Turquia também atuam ativamente nos bastidores do conflito. A Turquia pressiona pela retirada do governo Sírio, e representa o poder da OTAN na fronteira nortedaquele país, enquanto Israel, por meio do apoio estadunidense, utiliza da situação para criticar e ameaçar o Irã e seu programa nuclear. Todos estes elementos reforçam ainda mais o impasse na resolução do conflito, pois a disputa não se resolverá somente na arena doméstica, mas sim, em sintonia com as disputas regionais e mundiais.

\section{O Terceiro Nível de Análise - Das Grandes Potências.}

Durante o Século XIX, o Império Turco Otomano tentava a todo custo manter suas possessões na Europa e no Oriente Médio. O grande império que já havia conquistado terras da Índia às Portas de Viena agonizava lentamente no decorrer do século XIX. Ao final da Primeira Grande Guerra, outras potências disputavam o controle do Oriente Médio, notadamente Reino Unido e França, vencedoras guerra. Mesmo com a ascensão Estadunidense, seu isolacionismo não permitiu uma política mais incisiva na região, o que ocorrerá somente após a Segunda Grande Guerra. A Rússia Czarista também mantinha influência sobre a Pérsia, mas com a Revolução 


\section{Conjuntura Austral}

Socialista de 1917, não interferiu na partilha das zonas de influência entre Reino Unido e França.

Com a Segunda Grande Guerra, e principalmente após a crise do Canal de Suez, em 1956, dois novos atores irão polarizar as disputas na região, os Estados Unidos da América e a União Soviética. Esta polarização é um reflexo da própria ordem mundial inaugurada em 1947, que também terá seus efeitos no Oriente Médio.

A Síria, principalmente a partir do governo de Hafez al Assad (1971), manterá uma estreitarelação com a União Soviética, em função da própria ideologia do partido Baath (Socialismo Árabe), como também pelas relações pessoais que o presidente sírio manteve com aquele país. É importante destacar que o Presidente Hafez al Assad morou vários anos na União Soviética, como parte de sua formação militar e ideológica, o que também influenciará nas relações entre os dois países.

Estas boas relações permitiram um aumento do comércio, de alianças estratégicas militares, da importação de equipamento militar soviético, bem como do apoio político da União Soviética em caso de crises severas, como por exemplo, na Guerra do YonKippur em 1973. Por outro lado, a União Soviética obteve acesso ao mediterrâneo oriental a partir do Porto de Tartus, e mantinha uma importante zona de influência na região.

Ao mesmo tempo, Os Estados Unidos reforçaram sua aliança estratégica com Israel, funcionando como cabeça de ponte estadunidense na região e com o Iraque na década de 1970, para se contrapor à revolução iraniana. Já na década de 1990, em virtude da Primeira Guerra do Golfo, firmou alianças importantes junto ao governo saudita, kuaitiano e dos emirados do Golfo Pérsico.

Com o fim da Guerra Fria, e a decadência da Rússia como herdeira do Império Soviético (ao menos naquele momento), os Estados Unidos reforçaram sua presença na região, diminuindo paulatinamente as zonas de influência da Federação Russa. Os ataques de 11 de setembro aumentaram ainda mais a presença militar estadunidense noOriente Médio, em virtude da invasão do Afeganistão e da Segunda Guerra do Golfo contra o Iraque. A pressão sobre os principais antagonistas regionais eram evidentes, dentre eles o Irã, a Síria e o Hizballah no Líbano. Mesmo com todos os custos que as 


\section{Conjuntura Austral}

intervenções militares impuseram ao governo de George W. Bush, a sua presença naquela área não sofria contestação clara por parte de outra potencia mundial, mas sim, de grupos armados transnacionais.

O caso Sírio é importante, pois desde o fim da Guerra Fria, não se via uma disputa tão acirrada entre os Estados Unidos da América e a Federação Russa, em função da guerra civilnaquele país. Em virtude da defesa que os russos fazem da Síria, ameaçando vetar resoluções no Conselho de Segurança, ou mesmo afirmando que um ataque estadunidense sem uma Resolução das Nações Unidas poderia suscitar um apoio mais evidente por parte dos russos, que se percebe a importânciadesta disputa para o equilíbrio de poder regional e mundial. O que está em jogo não é simplesmente a deposição ou não de um ditador de seu posto, mas sim, compreender os prováveis resultados desta barganha política para o equilíbrio de forças nos três níveis de análise tratados neste artigo.

\section{O medo de se abrir a "Caixa de Pandora"}

Em agosto de 2013 as Nações Unidas declararam que existiam mais de 100.000 mortos no conflito interno da Síria (NAÇÕES UNIDAS, 2013)e que o número de refugiados havia ultrapassado 6,25 milhões, sendo que 4,25 milhões eram deslocados internos e 2 milhões de refugiados distribuídos pelospaíses vizinhos, notadamente no Líbano, Turquia, Jordânia, Egito e Magreb (Nações Unidas 2013).

A condição humanitária nas grandes cidades e vilas em agosto de 2013 eragravíssima $^{10}$, e a utilização de armas químicas(gás Sarin ${ }^{11}$ ) contra a população civil aprofundou ainda mais a pressão internacional contra o governo sírio. Como se não bastasse, os distúrbios internos no Líbano vêm se avolumando em função da polarização política do país, entre favoráveis e contrários ao atual governo Sírio.

\footnotetext{
${ }^{10}$ Excetuando Damasco e as regiões com forte presença das Forças Armadas, como as Províncias de Tartus, Latákia e Swaida. Estas regiões são caracterizadas por serem habitadas pelas minorias Alauitas, Drusas e Cristãs que apoiam o governo.

${ }^{11}$ Inspetores da ONU que visitaram a Periferia de Damasco, no bairro de Jobar, confirmaram o uso de armas químicas contra civis no dia 21 de agosto de 2013, mas não indicaram os responsáveis pelo ataque (NAÇÕES UNIDAS, 2013).
} 


\section{Conjuntura Austral}

Outro ponto de difícil controle é a multiplicação de grupos que integram as forças oposicionistas na Síria, sendo que parte destescontingentes é formada por estrangeiros que possuem ligações com grupos terroristas, como a $\mathrm{Al}$ Qaeda. Enfrentamentos entre grupos rebeldes já ocorrem no norte do país, o que revela a dificuldade da oposição em se organizar de maneira sólida.

A divisão geográfica criada pelo conflito é notória. As regiões historicamente divididas para os sunitas, nos antigos "Estados" de Alepo e Damasco representam os principais redutos da oposição (excetuando a capital Damasco e as disputadas cidades de Homs e Hama), sendo que as regiões com a maior presença das forças armadas sírias são aquelas ligadas às minorias, como o antigo "Estado Alauita"(em Tartus e Latakia), no JabalDruze (em Swaida e adjacências), em Damasco e em posições importantes com presença de minorias cristãs.

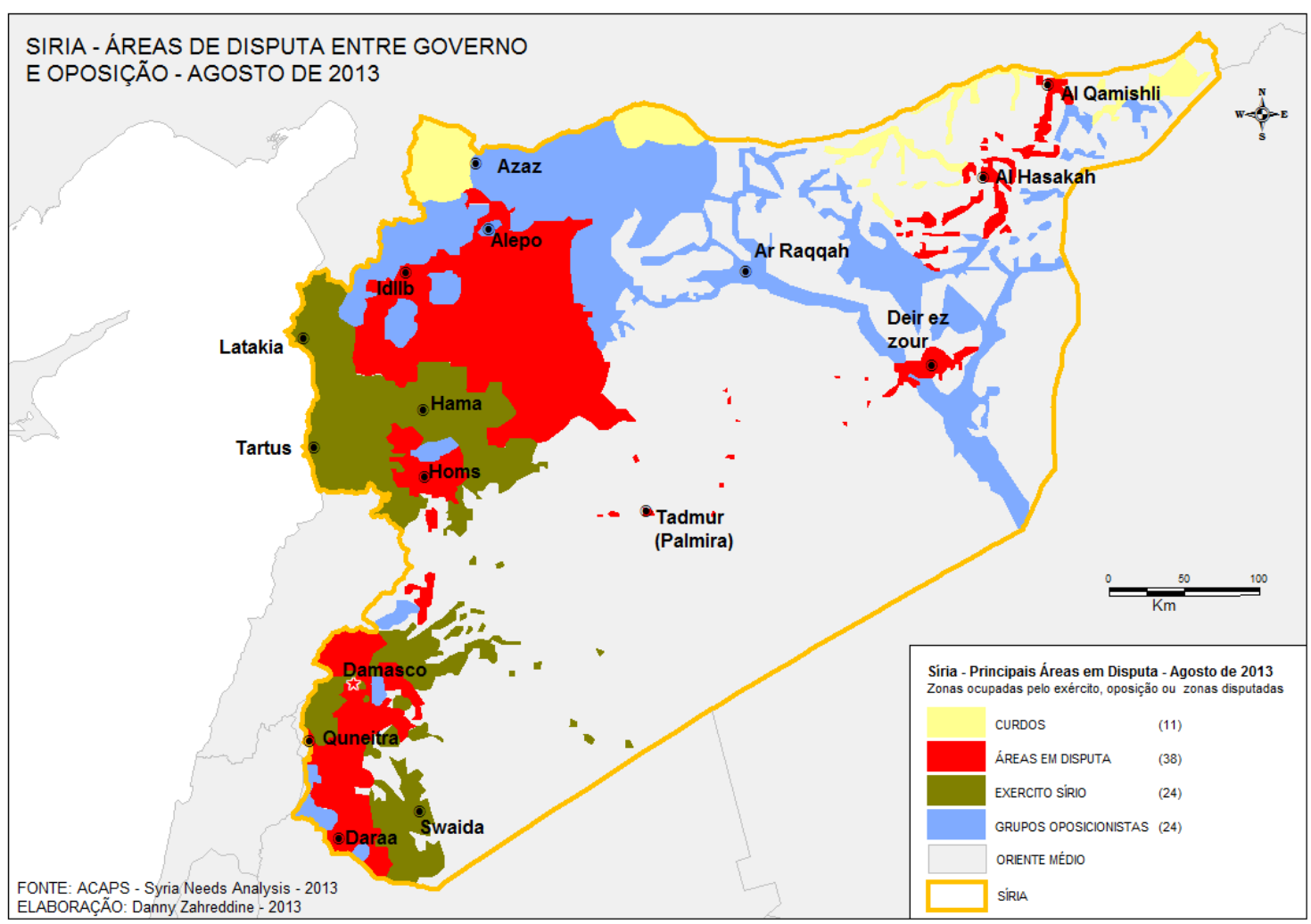

Para além de todos os aspectos geopolíticos e econômicos envolvidos no conflito, a tarefa mais árdua dos tomadores de decisão é avaliar as prováveis consequências da deposição ou não do presidente Bashar al Assad. Qual seria a relação 


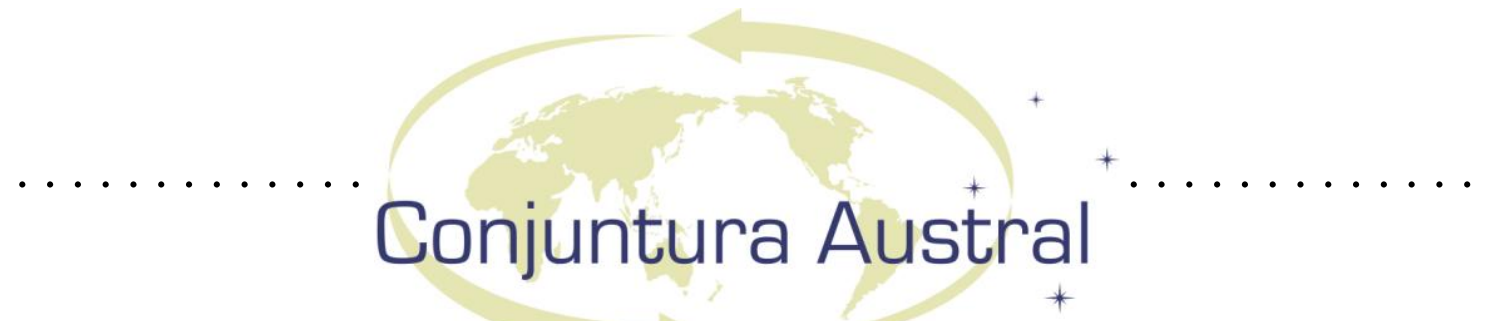

de um novo governo sunita frente às minorias alauitas, cristãs, drusas e curdas? Um provável governo sunita teria ligações mais fortes com o ocidente ou com um viés mais radical, em virtude dos grupos que formam a atual coalizão contra o presidente Bashar al Assad? Quais impactos a região sofreria com o fortalecimento saudita ou iraniano? E por último, o que significaria para a ordem regional e mundial a perda da influência russa sob a Síria?

O impasse na resolução do dilema sírio é fruto desta multidimensionalidade do conflito. A retroalimentação das forças governamentais e oposicionistas por seus respectivos aliados sejam eles domésticos, regionais ou potências mundiais, não permite o fim das hostilidades. Ambas as partes não alcançam o podernecessária para fazer com que a outraceda, gerando assim a estagnação do conflito, a manutenção da violência e o aumento da morte de civis. Além disto, aspectos religiosos, históricos e geográficos dificultam a solução do contencioso.

Para além do sofrimento sentido pela população civil, bem comoda destruição de seu patrimônio público e histórico,a incapacidade dos principais atores envolvidos no contencioso de atuar firmemente na busca de uma solução definitiva, é fruto do medo da abertura da "caixa de Pandora" ${ }^{12}$ ", o que pode ampliar e aprofundar o conflito. Neste caso, a preocupação das grandes potênciasenvolvidas reside no medo de um novo governo sírio que não possa ser controlado por nenhuma delas. Isto decorreria do grande espectro de forças que fazem parte da oposição, formada tanto por partidos moderados como por partidos radicais. A exemplo do que aconteceu com a sociedade afegã e iraquianaapós intervenções externas em pleno século XXI, o caso sírio pode apresentar características mais violentas, em razão da presença de forças transnacionais com projetos muito distintos, o que torna a conciliação entre as partes um desafio difícil de ser transposto.

\footnotetext{
${ }^{12}$ O Termo "Caixa de Pandora" têm origem na mitologia Grega. De acordo com o mito, a primeira mulher criada por Zeus, Pandora, recebeu uma caixa que continha todos os males da humanidade. Devido à sua curiosidade, Pandora abre a caixa, e sem se dar conta, permite que quase todos os males invadam o mundo. Assustada, Pandora fecha a caixa, e evita que o último dos males escape, aquele que destruiria a esperança.
} 


\section{Conjuntura Austral}

\section{REFERÊNCIAS}

BUZAN, Barry. From international to world society?: English school theory and the social structure of globalization. Cambridge: New York: Cambridge University Press, 2004.

BUZAN, Barry; WÆVER, Ole; WILDE, Jaap de.Security: a new framework for analysis. Boulder: Lynne Rienner, 1998.

CLEVELAND, William L.; BUNTON, Martin.A History of the Modern Middle East.Philadelphia: West View Press, 2009.

FROMKIN, David. Paz e Guerra no Oriente Médio. Rio de Janeiro: Editora Contraponto, 2008.

HOURANI, Albert Habib. Uma história dos povos árabes. São Paulo: Companhia das Letras, 1994.

LAKE, David; MORGAN, Patrick.Regional orders: Building security in a new world. Pennsylvania: PennsylvaniaStateUniversity Press. 1997.

MASSOUlIÉ, François. Os Conflitos do Oriente Médio. São Paulo: Editora Ática, 1996.

MOUBAYED, Sami. Stell\& Silk: men and woman who shaped Syria 1900 - 2000. Cune Press: Seattle, 2006.

NAÇÕES UNIDAS. Conflito na Síria. Disponível em: <http://www.onu.org.br/siria/> . Acesso em: 24 de setembro de 2013.

SANTOS FILHO, Onofre dos. Os movimentos contestatórios no Oriente Médio e no Norte da África: a Tunísia é a solução?. Estudos Internacionais: revista de relações internacionais, Belo Horizonte, MG, v.1, n.1, p.37-58, Obs. online, jan. 2013.

SEALE, Patrick. Assad:The struggle for the Middle east. Berkeley: University of California Press, 1989.

SEDDON, David. A Political and Economic Dictionary of the Middle East.New York: Taylor \& Francis Group, 2004.

SILVA, André Luiz Reis da.A atuação dos países emergentes na Assembleia Geral da ONU: as convergências da política externa brasileira com o Grupo Next Eleven (2000-2010). In: $4^{\circ}$ Encontro Nacional da ABRI, 2013, Belo Horizonte. ANAIS ELETRÔNICOS. Belo Horizonte: ABRI, 2013. 


\section{Conjuntura Austral}

TAYLOR, Alan R. The Arab Balance of Power (Contemporary Issues in the Middle East).Syracuse: Syracuse University Press, 1982.

YZADI, Michael. Syria Religious Composition.Disponível em: <http://gulf2000.columbia.edu/images/maps/Syria_Religion_Detailed_lg.png>. Acesso em: 24 de setembro de 2013.

ZAHREDDINE, Danny; LASMAR, Jorge Mascarenhas; TEIXEIRA, Rodrigo Corrêa. O Oriente Médio. Curitiba: Editora Juruá, 2011.

Artigo recebido dia 07 de outubro de 2013. Aprovado em 20 de outubro de 2013. 


\title{
Conjuntura Austral
}

\section{RESUMO}

Após mais de dois anos do início da revolta Síria, o embate entre governo e oposição continua intenso. A dificuldade de se quebrar o impasse entre os atores envolvidos reside na complexa rede de alianças e interesses que cercam a Síria. Este artigo abordará a crise síria em seu aspecto multidimensional, reforçando o papel das questões confessionais, históricas e geográficas do conflito. Para isto, será necessário um olhar em três níveis de análise: o doméstico, o regional e o sistêmico.

\section{PALAVRAS-CHAVE}

Síria; Oriente Médio; Conflito; Guerra Civil; Níveis de Análise.

\begin{abstract}
After more than two years since the beginning of the Syrian uprising, the clash between government and opposition remains intense. The difficulty of breaking the impasse between the actors involved is the complex network of alliances and interests surrounding Syria. This article will address the Syrian crisis in its multidimensional aspect, reinforcing the role of religious, historic and geographic issues of the conflict. For this, it is needed a view of three levels of analysis: domestic, regional and systemic.
\end{abstract}

\section{KEYWORDS}

Syria; Middle East; Conflict; Civil War; Analysis Levels 


\section{Conjuntura Austral}

\section{A IRMANDADE MUÇULMANA NA SÍRIA}

\section{The Muslim Brotherhood in Syria}

Guilherme Di Lorenzo Pires ${ }^{1}$

\section{Introdução}

Quando os protestos irromperam na Síria em 2011, um dos atores que ganhou destaque na mídia é a Irmandade Muçulmana. Objeto de interpretações distintas, a Irmandade Muçulmana é, em certa medida, uma incógnita para aqueles que tentam compreender o papel que ela desempenhou e desempenha nos movimentos sociais na Síria. A Irmandade Muçulmana tomara parte na escalada de violência na década de 1970, promovendo ataques contra integrantes de comunidades minoritárias, especialmente os alauitas, grupo ao qual pertence o presidente Bashar al-Assad e as principais lideranças do partido Ba'ath. A crescente tensão entre governo e oposição teve como desfecho trágico o "massacre de Hama" em 1982, quando o presidente Hafez al-Assad, pai do atual presidente, mandou bombardear Hama a fim de eliminar uma insurgência popular liderada por movimentos religiosos.

A princípio, o regime alcançou o objetivo esperado: as manifestações foram sufocadas e as lideranças da Irmandade Muçulmana buscaram refúgio no exílio. Contudo, como Raphael Lefevre (2013) observa, algumas tendências já existentes na década anterior se acentuaram após o massacre de Hama. A primeira foi o incentivo de uma minoria de opositores a buscar abrigo em organizações transnacionais na luta contra o regime. A outra tendência foi o crescente uso de símbolos islâmicos pelo regime de Assad como forma de legitimar o exercício do poder após o massacre, almejando esvaziar simbolicamente a relevância da oposição religiosa. Assim, em longo

\footnotetext{
${ }^{1}$ Mestre em Relações Internacionais pela Pontifícia Universidade Católica de Minas Gerais. E-mail: guilherme740@gmail.com
} 


\section{Conjuntura Austral}

prazo, estas tendências criariam um ambiente propício à difusão de movimentos de caráter religioso na Síria atual. Neste meio tempo, a Irmandade Muçulmana buscou se reorganizar no exterior e articular com outras lideranças marginalizadas uma nova oposição ao regime ditatorial. Porém, simultaneamente, a prudência política fez com que a organização adotasse gradualmente uma estratégia pragmática de negociação com o governo.

Esta ambiguidade não passou despercebida pelos grupos de oposição atuais que veem a atuação da Irmandade Muçulmana no Conselho Nacional Sírio com certa desconfiança. Portanto, para entender melhor o papel que a Irmandade Muçulmana desempenha hoje na Síria é preciso lançar um olhar histórico que registra as diversas etapas na relação que a organização manteve com a sociedade e com o governo.

\section{Origem da Irmandade Muçulmana na Síria}

A Irmandade Muçulmana foi um movimento social criado por Hassan al-Banna no Egito em 1928, que tinha como fundamento a renovação espiritual e a promoção do Islã enquanto princípio organizador de todas as esferas da vida social (MITCHELL, 1969). A partir da década de 1930, a Irmandade se difundiu na região através de filiais que eram estabelecidas em cada país (EL-AWAISI, 1998). No caso da Irmandade Muçulmana síria, é difícil estabelecer uma data de fundação devido ao processo gradual em que associações já existentes foram se unindo sob um novo "slogan". Assim, o que se observa é a introdução paulatina das ideias de Hassan al-Banna pelo meio de jovens sírios que estudaram no Cairo. Estes jovens formavam nas principais cidades sírias uma rede de associações voltadas ao bem estar social e que se desenvolveram entre as classes urbanas médias e baixas nas décadas de 1920 e 1930. Deste modo, é melhor pensar em um "período de gestação" que abarcaria as décadas de 1930 e 1945 . Nestes anos, a vida política e intelectual da rede de associações que passara a se denominar Irmandade Muçulmana na Síria esteve intimamente conectada à sua irmã no Egito. Inclusive, durante a repressão promovida pelo governo de Nasser no Egito contra a Irmandade em 1954, o líder da Irmandade Síria, Mustafa al-Sibai, tomou a vanguarda do movimento (CARRÉ; MICHAUD, 1983). Entretanto, a dinâmica histórica dos respectivos países 


\section{Conjuntura Austral}

conduziu as duas organizações por caminhos diferentes, impossibilitando caracterizar a Irmandade Muçulmana síria como uma extensão da sua matriz egípcia. Avaliando a particularidade social síria, Olivier Carré e Gérard Michaud (1983) argumentam que os movimentos Islamistas na Síria, mais que movimentos sociais ou correntes doutrinárias, eles devem ser entendidos como a reação de uma comunidade sunita que, mesmo representando a maioria na sociedade, encontrava-se (e ainda encontra-se) apartada do poder.

Por outro lado, a Irmandade Muçulmana síria não apresentou o mesmo apelo popular que a Irmandade egípcia. Joshua Teitelbaum (2011) observa que durante o período de 1945 e 1958, o grupo de al-Sibai foi um corpo político que participou abertamente das eleições parlamentares desde que o país obteve a independência em 1946, ganhando quatro assentos em 1947, três em 1949, cinco em 1954 e dez assentos em 1961 (HINNEBUSCH, 1982). Como reflexo do envolvimento político, o discurso da organização síria enfatizava a natureza universal da sua mensagem e condenava o sectarismo. O pensamento da Irmandade Muçulmana síria, em contraste com o descaso de Hassan al-Banna em relação às outras religiões (MITCHELL, 1969, p.230), tinha uma visão nuançada da relação entre a sociedade islâmica e as minorias religiosas, enfatizando o apelo universal da identidade árabe. Além disso, a Irmandade síria precisava contar com o apoio eleitoral das minorias na competição política marcada pela diversidade de partidos políticos. Contudo, mesmo em tal proposição universalista é possível vislumbrar uma preocupação do grupo em proteger a comunidade sunita frente a uma possível contenda com as outras comunidades (LEFEVRE, 2013). Por fim, é importante destacar uma diferença capital entre as duas organizações no que diz respeito ao envolvimento com as instituições religiosas tradicionais: por um lado, a Irmandade egípcia se fundamentou em oposição aos ulemás e à universidade de Al-Azhar, percebida como uma instituição domesticada pelo regime dos oficiais livres; no grupo sírio, por sua vez, os ulemás tiveram um papel importante na direção do movimento (TEITELBAUM, 2011).

Estas diferenças quanto à orientação política e ideológica refletem tanto a composição social de cada organização como as dinâmicas sociais nas quais estão 


\section{Conjuntura Austral}

inseridas. No Egito, a organização era um movimento de massa contando com algo entre 200.000 e 600.000 membros (MITCHELL, 1969), ao passo que na Síria a organização tinha entre 10.000 e 12.000 integrantes. Neste aspecto, a Irmandade Muçulmana na Síria era um movimento, entre tantos, no cenário político. Além disso, ela não conseguiu estabelecer uma mesma rede extensiva de ramificações e células tão característica da organização egípcia. Portanto, a Irmandade Muçulmana síria foi um fenômeno urbano vinculado às classes médias e que disputava com outros partidos o eleitorado urbano. Mas, em contraste com os partidos seculares, a Irmandade Muçulmana contou com o apoio da classe média tradicional sunita, composta por pequenos comerciantes, professores e ulemás. Ainda assim, apesar de contar com uma rede de mesquitas, a Irmandade Muçulmana síria nunca conseguiu estabelecer um movimento popular vasto e bem estruturado - como conseguiu o partido Ba'ath - pois os ulemás que lideravam a Irmandade na Síria não favoreciam estratégias para o estabelecimento de movimento de massa. (TEITELBAUM, 2011, p.219).

\section{Oposição da Irmandade Muçulmana ao partido Ba'ath}

Quando o partido secular Ba'ath tomou o poder em 1963, ele estava disposto a enfraquecer a Irmandade Muçulmana e a classe comerciante sunita que apoiava a organização (HINNEBUSCH, 1982). A Irmandade foi declarada ilegal em 1964 e meses depois uma revolta irrompeu na cidade de Hama. A agitação, que começara no meio colegial, logo foi assumida por grupos religiosos que declaram guerra santa contra o partido no poder. Em resposta, o general Amin al-Hafez, presidente do Conselho da Revolução, ordenou o bombardeamento da mesquita al-Sultan, um gesto que comprometeu ainda mais a imagem do partido Ba'ath entre os religiosos. Em consequência, o descontentamento se generalizou, ganhando as grandes vilas, onde as classes liberais e os estudantes exigiam a restauração das liberdades políticas e o fim do "estado de exceção". Sobre o panorama social dos protestos, Olivier Carré e Gerard Michaud (1983) notam que as classes sociais envolvidas nas manifestações de 1964 eram praticamente as mesmas daquelas que foram reprimidas em 1982. 


\section{Conjuntura Austral}

Raphael Lefevre (2013), por sua vez, argumenta que o golpe de 1963 representa uma mudança na ordem política síria; mudança que afetaria profundamente a dinâmica entre os movimentos sociais e políticos nos anos subsequentes, inclusive a Irmandade Muçulmana. Até 1963, membros da classe alta de Alepo, Hama e Damasco estiveram no poder, mas com o advento do partido Ba'ath, a Síria passou a ser governada por homens de origens camponesas, geralmente associados a minorias religiosas de regiões mais periféricas como a Latakia e Dar'a.

Com o segundo golpe dentro do partido Ba'ath em 1966 que delimitou a liderança do partido Ba'ath ao grupo alauíta, a Irmandade Muçulmana intensificou as críticas ao novo regime e adotou uma postura mais hostil em relação às minorias étnicas e religiosas (TEITELBAUM, 2011). Os alauítas eram considerados pela opinião tradicional sunita como uma seita herética, e o domínio do aparelho estatal por integrantes da comunidade alauíta impeliu a comunidade sunita a demonstrar insatisfação. Gradualmente, a percepção de domínio por um grupo minoritário desencadeou posturas sectárias entre membros da Irmandade Muçulmana, que abandonava, com isso, a atitude de compromisso político das décadas anteriores.

Após a subida ao poder do presidente Hafez al-Assad em novembro de 1970, a relação entre a Irmandade Muçulmana e o regime se deteriorou ainda mais levando a uma escalada da violência. Quando Hafez al-Assad deu o golpe dentro do regime, ele promoveu uma série de mudanças que transformaram o partido Ba'ath em um instrumento de articulação para uma elite bem delimitada em torno da figura do presidente. Além disso, a exclusão política da Irmandade Muçulmana, junto com a secularização promovida pelo regime e das medidas "populistas" que ameaçavam as bases socioeconômicas, restringiram o espaço de atuação tradicional da Irmandade e a autonomia do grupo (KHATIB, 2011, pp.55-65). Diante de tal cenário, a Irmandade começou a atuar em espaços privados e a divulgar uma mensagem que traduzia a insatisfação de fração da sociedade síria em um discurso religioso. Portanto, a questão religiosa conferiu profundidade e densidade a uma oposição que já estava presente desde a década de 1960, na sociedade síria (LEFEVRE, 2013, p.43). 


\section{Conjuntura Austral}

Após a invasão Síria do Líbano em 1976, movimentos sunitas, incluindo a Irmandade Muçulmana, iniciaram um levante promovendo guerrilhas contra forças do governo. Em 1979, esta oposição chegou a um nível crítico ao ponto de ameaçar seriamente a rede de segurança e inteligência do regime, passando de escaramuças isoladas a uma revolta popular mais ampla. Em 1979, membros da Irmandade promoveram o assassinato de 83 cadetes alauítas em um quartel em Alepo. Em 1980, o regime declarou pena capital para a filiação à Irmandade Muçulmana, e em resposta a organização intensificou os ataques contra alvos vinculados ao governo, incluindo uma tentativa de assassinato do presidente. O governo respondeu com ordens de prisão e torturas de centenas de integrantes da Irmandade Muçulmana. Ainda assim, organização manteve suas atividades em centros urbanos predominantemente sunitas como Damasco e Hama (TALHAMY, 2012). Durante o período de junho de 1980 a junho de 1981, execuções sumárias e torturas eram cada vez mais frequentes. (ABD ALLAH, 1983). Em três de fevereiro de 1982, uma unidade militar do governo fora emboscada por guerrilheiros na cidade de Hama, e a oposição declarou o início da sedição. A reação do Governo foi imediata e iniciou o sítio à cidade. Após o bombardeio de Hama, o que se seguiu foi uma campanha de tortura e execuções sumárias visando eliminar as lideranças e os simpatizantes da Irmandade Muçulmana. E após o massacre, a Irmandade Muçulmana foi obrigada a deixar a Síria e a liderança se dispersou no exílio.

Como consequência do Massacre de Hama, a Irmandade Muçulmana deixou de ser uma organização atuante na sociedade síria e foi substituída por outros movimentos, nacionais e transnacionais, que deram continuidade à militância contra o regime sírio (LEFEVRE, 2013). Por outro lado, a Irmandade Muçulmana passou por um processo de revitalização e reinterpretação da própria história durante a década de 1990, buscando se aproximar de outros movimentos de oposição ao regime de Assad. Em dezembro de 2004, a Irmandade expressou a aspiração para o estabelecimento de um Estado civil moderno na Síria através da promoção do pluralismo, do Direito e de uma sociedade civil forte. Em outubro de 2005, a organização se aliou a outros cinco partidos seculares e figuras independentes na assinatura da Declaração de Damasco, a qual defendia o estabelecimento de um regime nacional democrático. Além disso, a declaração pedia 


\section{Conjuntura Austral}

uma reforma que fosse pacífica, gradual e fundada no diálogo e no reconhecimento de todos os grupos políticos (TALHAMY, 2012). Alguns meses depois, em março de 2006, a Irmandade Muçulmana se aproximou do antigo vice-presidente Abd al-Halim Khaddam, um dos homens poderosos do regime até ser deposto em 2005, e, junto com outros exilados sírios, estabeleceram a Frente de Salvação Nacional.

Entretanto, ao mesmo tempo em que arquitetava alianças contestando o regime, a liderança da Irmandade iniciou negociações secretas com o governo, oferecendo acomodação política desde que o regime aceitasse o retorno de alguns membros. Com a ascensão de Bashar al-Assad ao poder em 2000, o regime deu prosseguimento a esta negociação, permitido o retorno de alguns integrantes à Síria. Em resposta, a Irmandade renunciou ao uso da violência e deu sinais de estar disposta a reconhecer a legitimidade de Bashar al-Assad. Esta postura pragmática foi mantida pelo grupo até o começo das revoltas em 2011, quando a organização declarou abertamente o apoio aos protestantes, mas negou a responsabilidade ou envolvimento na mobilização popular contra o regime (TALHAMY, 2012).

\section{A atuação da Irmandade Muçulmana no conflito sírio}

Desde o início dos protestos em 2011, a Irmandade Muçulmana cooperou com grupos seculares e atuou nos principais órgãos da oposição: o Conselho Nacional e a Coalizão Nacional Síria. Foi através destas entidades que a Irmandade Muçulmana conseguiu se projetar como um ator importante. Desde a criação em outubro de 2011, o Conselho Nacional Sírio buscou angariar apoio internacional ao mesmo tempo em que se apresentava como a entidade política legítima da oposição Síria. Porém, mesmo contando com o apoio internacional, o Conselho Nacional passou a ser contestado entre os movimentos de oposição, pois estes consideravam o Conselho uma entidade que carecia de legitimidade doméstica, sendo percebido como instrumento político da Irmandade Muçulmana. Com isso, outra aliança política foi estabelecida, a Coalizão Nacional, com a intenção de contemplar uma maior heterogeneidade política que representasse todos os movimentos de oposição (LUND, 2013). Mas mesmo assim, a Irmandade Muçulmana preservou um papel importante na nova entidade. Neste aspecto, 


\section{Conjuntura Austral}

é importante observar como o apoio externo foi fundamental para a proeminência da Irmandade Muçulmana nestes órgãos. A Turquia, com o governo do partido AKP, abrigou alguns dos líderes exilados da Irmandade e ajudou diretamente na organização das conferências. A Irmandade Muçulmana também é favorecida politicamente e financeiramente pelo governo do Qatar.

Mas a despeito do protagonismo nestes órgãos, a Irmandade não é capaz de influenciar profundamente o desenrolar dos eventos dentro da Síria. A idade avançada e a origem na classe média de grande parte da liderança tradicional são obstáculos para a conexão da Irmandade com ativistas mais jovens das áreas mais pobres e rurais. Diante destas limitações, a estratégia adotada pela Irmandade é caracterizada por uma atitude reativa. Basicamente, ela tenta atuar conjuntamente com outros grupos. O principal espaço de atuação da Irmandade se encontra nos círculos privados. É através de laços individuais que ela consegue introduzir seus interesses na agenda política da oposição e financiar grupos paramilitares na luta contra o regime. Contudo, o apoio aos grupos paramilitares não significa que a Irmandade tenha abandonado o compromisso com o pluralismo político. Pois, apesar das aspirações teocráticas e do passado de violência sectária, a Irmandade Muçulmana promove uma abordagem Islamista moderada.

Desta forma, avaliar a real importância do papel da Irmandade Muçulmana no conflito na Síria é difícil, pois ela atua principalmente por meio de redes informais. Publicamente, ela adota uma postura de contenção, mas através de contatos individuais, ela consegue cooptar lideranças e figuras importantes. Esta tendência também ocorre no financiamento de grupos paramilitares. Contudo, não se pode induzir que o financiamento de movimentos de oposição transforme a Irmandade em um ator que dita as regras. (LUND, 2013). Trata-se de uma aproximação por necessidade e não resultado de uma verdadeira afinidade ideológica. Além do mais, a Irmandade é vista por estes grupos como uma fonte de recursos entre muitas.

\section{Conclusão}

A Irmandade Muçulmana síria não é uma simples ramificação de uma tendência global, mas poderia ser mais bem descrita como uma expressão orgânica de uma classe- 


\section{Conjuntura Austral}

média e de um conservadorismo sunita urbano. Contudo, o longo exílio da Irmandade Muçulmana comprometeu o esforço da organização em se apresentar como um ator relevante para a sociedade síria atual. Assim, a ausência de uma voz moderada propiciou a fragmentação e a diversificação dos movimentos religiosos, abrindo espaço para movimentos de natureza mais radical (LEFREVRE, 2013). Em oposição a este hiato histórico, a Irmandade Muçulmana busca legitimar suas pretensões de porta-voz da população síria a partir da memória histórica de oposição do grupo ao governo autoritário. Realmente, é preciso destacar a eficiência da estrutura organizacional da Irmandade Muçulmana que contribuiu para o ressurgimento do grupo nos últimos anos. Porém, isso não quer dizer que a Irmandade Muçulmana encontre um amplo respaldo social, pois grande parte da sociedade síria vê com certa desconfiança a atuação da Irmandade no cenário político contemporâneo. Mais do que a ideologia religiosa, é a história de volatilidade política e interesses conservadores que fazem com que a Irmandade seja um grupo contestado entre a oposição política. Desta forma, os objetivos políticos últimos da organização ainda não são claros e evidentes para boa parte da sociedade síria, a qual nunca expressou o mesmo fascínio pela organização tal como ocorreu com a sua irmã no Egito (TALHAMY, 2012).

Quando as revoltas irromperam em 2011, a Irmandade Muçulmana era o grupo da oposição mais bem organizado e estruturado. Contudo, a Irmandade é uma organização que não está enraizada na sociedade síria, e a liderança no exílio luta agora para influenciar as gerações mais jovens. Além do exílio e da disputa entre as gerações, a Irmandade se vê diante de mais dois desafios. Por um lado, as divisões internas entre as vertentes de Hama e de Alepo ameaçam a coesão do grupo, já bastante debilitada. Por outro lado, a ascensão de grupos Salafistas militantes que questionam a ideologia moderada e pragmática da Irmandade cria um obstáculo para o recrutamento de adeptos entre a juventude sunita. Mas ainda assim, é importante ressaltar que a incapacidade dos outros movimentos políticos de se articularem de forma coerente confere à Irmandade Muçulmana um peso desproporcional à capacidade dela de mobilizar grupos dentro da Síria. Deste modo, a despeito de todas as fragilidades, a Irmandade Muçulmana permanecerá um ator relevante cenário político sírio. 


\section{Conjuntura Austral}

\section{REFERÊNCIAS}

ABD-ALLAH. Umar F.. Islamic Struggle in Syria. Berkeley: Mizan press, 1983.

CARRÉ, Olivier; MICHAUD, Gérard. Les Frères Musulmans: Egypte et Syrie (1928-1982). Paris: Gallimard.1983.

EL-AWAISI, Abd al-Fattah. The Muslim Brothers and the Palestine question 19281947. London: I.B. Tauris, 1998.

HINNEBUSCH, Raymond A.. The Islamic Movement in Syria: Sectarian Conflict and Urban Rebellion in an Authoritarian-Populist Regime. In DESSOUKI, Ali El Deen Hillal (ed.). Islamic Resurgence in the Arab World. New York: Praeger, 1982.

KHATIB, Line. Islamic Revivalism in Syria: The Rise and Fall of Ba'thist Secularism. New York: Routledge, 2011.

LEFEVRE, Raphael. Ashes of Hama: The Muslim Brotherhood in Syria. New York: Oxford University Press, 2013.

LUND, Aron. Struggling to Adapt: The Muslim Brotherhood in a new Syria. In: The Carnegie Papers. Maio, 2013.

MITCHELL, Richard P. The Society of the Muslim Brothers. New York: Oxford University Press, 1969.

TALHAMY, Yvette. The Syrian Uprising: The Muslim Brotherhood Reborn. In: Middle East Quarterly. Spring, 2012, pp.33-40.

TEITELBAUM, Joshua. The Muslim Brotherhood in Syria, 1945-1958: Founding, Social Origins, Ideology. In: The Middle East Journal. Vol.65, n.2, spring 2011, pp.213-233.

Artigo recebido dia 05 de outubro de 2013. Aprovado em 22 de outubro de 2013. 


\title{
Conjuntura Austral
}

\section{RESUMO}

O objetivo deste artigo é traçar brevemente a história da Irmandade Muçulmana na Síria e a relação da organização com a política síria. Serão abordados a fundação da organização na década de 1930, a radicalização na década de 1970, o exílio subsequente e, finalmente, o retorno na década de 2000.

\section{PALAVRAS-CHAVE}

Movimentos sociais; Islã Político; Síria.

\begin{abstract}
The objective of this paper is to draw briefly the history of the Muslim Brotherhood in Syria and its relation with the Syrian politics. It will be studied the organization's foundation in the 1930's, the radicalization in 1970's, its subsequent exile, and, finally, the comeback at 2000's.
\end{abstract}

\section{KEYWORDS}

Social Movements; Political Islam; Syria 


\title{
Conjuntura Austral
}

\section{A POSIÇÃO BRASILEIRA FRENTE AO CONFLITO NA SÍRIA (2011-2013)}

\section{The Brazilian Position in Syria’s Conflict}

\author{
Bruna Figueiredo Riediger ${ }^{1}$
}

\section{Introdução}

Em janeiro de 2011, enquanto o Mundo Árabe dava seus primeiros passos em direção a uma onda de revoltas que logo englobaria vários países da região, no Brasil, a presidente Dilma Rousseff tomava posse sob o signo da continuidade. Seu antecessor, o presidente Luís Inácio Lula da Silva, fora responsável, juntamente com o Ministro das Relações Exteriores do seu governo, Celso Amorim, por uma política externa ativa e demandante frente aos países centrais. Entre as grandes diretrizes de sua atuação externa estava a diversificaçãode parceiros e, nesse ínterim, o Mundo Árabe recebeu nova atenção na agenda diplomática brasileira. O grande marco da aproximação com a região foi a instituição das cúpulas América do Sul-Países Árabes pelo Brasil, que, até o momento, tiveram três encontros ${ }^{2}$.

Assim, quando Dilma Rousseff assumiu o poder, o Brasil encontrava-se em um novo patamar no cenário internacional, devido ao reconhecimento dos demais países da elevação do perfil do Brasil. No entanto, o contexto internacional também não era mais o mesmo. Enquanto o presidente Lula ocupou o cargo em um período predominantemente favorável em termos econômicos, a presidente Dilma assumiu em um momento de grave crise econômica internacional.

\footnotetext{
1 Mestranda no Programa de Pós Graduação em Estudos Estratégicos Internacionais (PPGEEI) na UFRGS. Graduada em Relações Internacionais pela mesma universidade. E-mail: brunariediger@gmail.com

${ }^{2}$ Cúpulas de 2005, em Brasília; 2009, em Doha e 2012, em Lima.
} 


\section{Conjuntura Austral}

Dessa feita - e também devido à própria formação da presidente, que é graduada em economia - sua política externa foi grandemente influenciada por questões econômicas, com grande foco na reforma das instituições financeiras internacionais e na busca de oportunidades para o Brasil. A instituição do programa Ciências sem Fronteiras ainda em 2011, que prevê a concessão de até 101 mil bolsas de intercâmbio em quatro anos para que estudantes brasileiros possam ter contato com sistemas educacionais competitivos em relação à tecnologia e inovação, foi um dos grandes pontos da atuação externa do Brasil no governo de Dilma.

O Mundo Árabe, por sua vez, encontrava-se em um turbilhão. O início dos protestos, que posteriormente convencionou-se chamar de Primavera Árabe, teve início ainda em dezembro de 2010, na Tunísia, com a autoimolação de um vendedor do interior do país. Em pouco tempo, a revolta - que tem em sua raiz, de acordo com Anderson (2011), enormes pressões sociais, como desigualdade social, aumento do custo dos alimentos, falta de moradia e ausência de emprego para a juventude espalhou-se para outros países da região. Em janeiro de 2011, o chefe de governo tunisiano, Zine elAbidine Ben Ali já havia sido deposto, e Egito, Iêmen, Líbia, Argélia, Bahrein enfrentavam grandes protestos. Em 11 de fevereiro, Hosni Mubarak, no poder no Egito há 30 anos, renunciou. Em 17 de março, uma resolução do Conselho de Segurança abriu espaço para a intervenção militar da OTAN na Líbia, sob o princípio da responsabilidade de proteger, visto que a violência contra os civis atingira um nível crítico. Em agosto, caía o general MuamarKadaffi, no poder na Líbiadesde 1969.

Na Síria, no entanto, os protestos estouraram somente em março de 2011, e seu desenlace não foi similar ao egípcio, onde os protestos populares conseguiram derrubar Mubarak; nem ao líbio, onde uma intervenção militar estrangeira ajudou os rebeldes que depuseram e mataram Kadaffi. Na Síria, os protestos evoluíram para uma guerra civil, levando à morte de milhares e deslocando milhões ${ }^{3}$. O presidente Bashar Al Assad recusa-se a sair do poder e nunca negociou com os rebeldes; o Conselho de Segurança

\footnotetext{
${ }^{3}$ De acordo com o Alto Comissariado das Nações Unidas para os Direitos Humanos (ACNUDH) são mais de 100 mil mortos desde março de 2011, com estimativas de 4,25 milhões de deslocados internos e 2 milhões de refugiados sírios nos países vizinhos e no norte da África. (ONU BRASIL, sem data)
} 


\section{Conjuntura Austral}

das Nações Unidas, por sua vez, não conseguiu aprovar uma intervenção militar, como fez no caso líbio, devido aos vetos russo e chinês.

Esse trabalho tem, então, por intento, analisar qual foi e como evoluiu a posição brasileira frente à situação síria durante esses quase três anos de conflito no país. Para isso, primeiramente, tratar-se-á brevemente do conflito, de como esse evoluiu de simples demandas da população por mais liberdade e direitos políticos para uma guerra civil sectária que se desenrola há mais de dois anos. Posteriormente, apresentar-se-á, então, a posição adotada pelo Brasil em relação ao conflito.

\section{O Desenrolar do Conflito Sírio (2011-2013)}

$\mathrm{Na}$ onda de protestos que se desenvolveuno Mundo Árabe no início de 2011, a Síria, país governado pelos Assad desde 1970 sob estado de emergência, não ficou para trás. Em fevereiro, foi convocado, com inspiração nos protestos dos países vizinhos, o "dia de fúria", que acabou por não atrair muitos manifestantes, diferenciando-se, dessa forma, dos demais países, onde milhares saíram às ruas. (NEW YORK TIMES, 2011)

Em março, contudo, a situação foi diferenciada, e as manifestações públicas pacíficas tiveram início simultaneamente em diversas cidades, reivindicando maiores liberdades políticas e individuais. Além disso, outra demanda dos manifestantes dizia respeito à situação dos prisioneiros políticos - alguns presos desde a década de 1970, quando do golpe de Hafez al Assad, pai de Bashar, hoje no poder. Os protestos continuaram durante todo o mês de março, e a cidade de Dera'afoi um de seus importantes focos. A prisão de um grupo de menores de 17 anos por picharem palavras contra o regime insuflou ainda mais a população. No final de março, a repressão contra os protestos se instalou e dezenas foram mortos em Dera'a quando as forças de segurança abriram fogo contra os manifestantes. (TERRA,2013; PEÇANHA et al, 2012)

Em 24 de março, o governo anunciou alguns planos, como o aumento dos salários dos funcionários públicos e a possibilidade de suspender a lei de emergência, na tentativa de acalmar os cidadãos. Em 30 de março, o presidente Assad finalmente se dirigiu à população. Em seu discurso, reconheceu que não atendera às necessidades do 


\section{Conjuntura Austral}

povo sírio, contudo, não ofereceu nenhuma mudança concreta. Os protestos continuaram e em 19 de abril, o presidente suspendeu a lei de emergência, vigente no país há 48 anos. (CNN, 2013, TERRA, 2013)

Desde então, o processo passou por uma escalada crescente de violência. Os protestos, inicialmente pacíficos, transformaram-se em combates e a oposição ao regime armou-se - no entanto, até hoje, ela encontra-se dividida em várias facções. Internacionalmente, os Estados Unidos impuseram diversas sanções, congelando ativos do governo sírio. A União Europeia, por sua vez, baniu a importação do petróleo sírio, impôs sanções adicionais e embargou a venda de armas.

No mês de agosto de 2011, a Liga Árabe quebrou seu silêncio e por meio do secretário-geral, Nabil al-Arabi, pediu o fim imediato da violência na Síria. Em setembro, o premiê turco, Recep Tayyip Erdogan, anunciou o rompimento do diálogo com a Síria. Em novembro, a Síria foi suspensa da Liga Árabe, em um dos maiores movimentos de pressão da comunidade árabe internacional sobre Damasco. Ainda em novembro, a Turquia e a Liga Árabe emitiram um comunicado conjunto em que se colocaram contra qualquer intervenção militar na Síria. Em dezembro, após meses de negociação, chegou ao país o primeiro grupo de observadores árabes, com o objetivo de verificar a situação interna. Em março de 2012, Kofi Annan, enviado especial da ONU e da Liga Árabe chegou a Damasco para encontrar-se com Assad e discutir maneiras de por fim à violência. (TERRA, 2013)

No Conselho de Segurança, por sua vez, nenhuma resolução foi aprovada devido aos vetos russo e chinês. Já no Conselho de Direitos Humanos, uma resolução condenatória ao regime sírio foi aprovada em novembro de 2011 e em março de 2012, reivindicando o fim imediato das violações dos direitos humanos e dos ataques contra civis.

Atualmente, mais de dois anos e meio depois do início do conflito, as estimativas do Observatório Sírio para os Direitos Humanos são de mais de 115 mil mortos, sendo 5 mil só do mês de setembro de 2013, além disso, de acordo com a ONU, o número de pessoas que deixou a Síria aproxima-se de 2 milhões. Nesse período de conflito, foram dois os enviados especiais da ONU e da Liga Árabe para o país - Kofi 


\section{Conjuntura Austral}

Annan, que teve seu cessar-fogo e plano de paz fracassado, eLakhdarBrahimi, que assumiu o cargo quando Annan renunciou em agosto de 2012. (ONU BRASIL, sem data)

Com diversos picos de violência e informações de massacres de civis, pode-se afirmar que um dos momentos mais críticos do conflito ocorreu no final de agosto de 2013, quando foi denunciado um ataque químico nos arredores de Damasco, que deixou centenas de mortos. As informações em relação ao ataque são divergentes e incompletas, contudo, a possibilidade de uma intervenção estrangeira no país tornou-se muito mais provável, visto que o presidente Barack Obama havia traçado uma linha vermelha em relação ao uso de armas químicas no conflito.

O presidente Putin, no entanto, anunciou uma proposta para colocar as armas químicas sírias sob controle internacional, proposta que foi aceita tanto por Obama quanto por Assad. Assim, em 12 de setembro, a Síria se tornou um membro pleno do tratado global contra armas químicas, comprometendo-se com o plano russo inicial de entregar seu arsenal para destruição. (REUTERS, 2013) O acordo impediu uma intervenção externa na Síria, todavia, de que modoa destruição de suas armas químicas porá fim ao longo conflito sanguinário interno não está claro.

\section{A Política Externa Brasileira Face ao Conflito na Síria}

A política externa de Dilma Rousseffapesar de ser mais discreta que a de Lula da Silva, manteve diversos traços de continuidade tais como a ênfase nas relações com os países em desenvolvimento e a busca por autonomia em relação aos países centrais, assim como por maior protagonismo no sistema internacional. A mudança de estilo quanto à sua condução, no entanto, é claramente perceptível. Enquanto o presidente Lula envolvia-se na maioria dos assuntos e viagens internacionais, a presidente Dilma acaba delegando grande parte dessas tarefas, tendo um histórico de viagens internacionais bem menor que a de seu antecessor. Nesse sentido, Pecequilo destaca que, apesar da agenda internacional do País ter sido mantida de forma predominante, as diferenças são perceptíveis "no sentido tático-estratégico de realização dessa agenda, 


\section{Conjuntura Austral}

que vem sendo perseguida com menor intensidade e com baixo perfil”. (PECEQUILO in OJEDA, 2013)

O discurso constante da necessidade de uma ordem internacional mais justa e equitativa do governo anterior continua presente com Dilma, sendo que essa adicionou uma nova ênfase na ação externa do país: "a prioridade atribuída a ciência, tecnologia e inovação, com vistas a contribuir para a ascensão do Brasil a um novo estágio de desenvolvimento, fundado em uma economia mais flexível e competitiva". (PATRIOTA, 2012) Além disso, a necessidade de reforma do Conselho de Segurança um dos grandes objetivos do governo Lula - também é bastante destacada por Dilma Rousseff e Antônio Patriota, chanceler de seu governo entre janeiro de 2011 e agosto de $2013^{4}$. Este, por exemplo, destacou em entrevista ao Estado de São Paulo, em 17 de julho de 2011:

(...) o Conselho está se tornando anacrônico. Isso é preocupante porque, se o conselho se tornar anacrônico durante muito tempo mais, os países, talvez regiões inteiras, podem deixar de respeitar suas decisões. Isso tem potencial para gerar uma crise política séria no ordenamento internacional. (PATRIOTA, 2011)

Em artigo de 2013, o Ministro ressaltava:

A paralisia em questões de paz e segurança internacional pode ser
considerada o mais preocupante exemplo da estagnação do sistema de
governança mundial. O CSNU, congelado em configuração de poder
anacrônica, é o foro que debate e pode chegar a autorizar o uso da força para
a proteção de civis. Um CSNU mais legítimo e representativo disporá de
melhores condições para implementar medidas preventivas e estratégias
diplomáticas que evitem a radicalização e solucionem conflitos.
(PATRIOTA, 2013)

Aquestão da reforma do Conselho foi fortemente destacada nos discursos e entrevistas, englobando a situação no Mundo Árabe, principalmente o conflito na Síria, visto que o Conselho ficou paralisado e incapaz de aprovar qualquer resolução sobre a situação que se desenrola no país há mais de dois anos. Nesse sentido, em relação às revoltas que estouraram na região ainda no primeiro mês de presidência de Dilma, o governo brasileiro destacou, desde o início, que apoiava as "aspirações à liberdade e à democracia dos povos", ressaltando, no entanto, que "considera que intervenções

\footnotetext{
${ }^{4}$ Substituído por Luiz Alberto Figueiredo.
} 


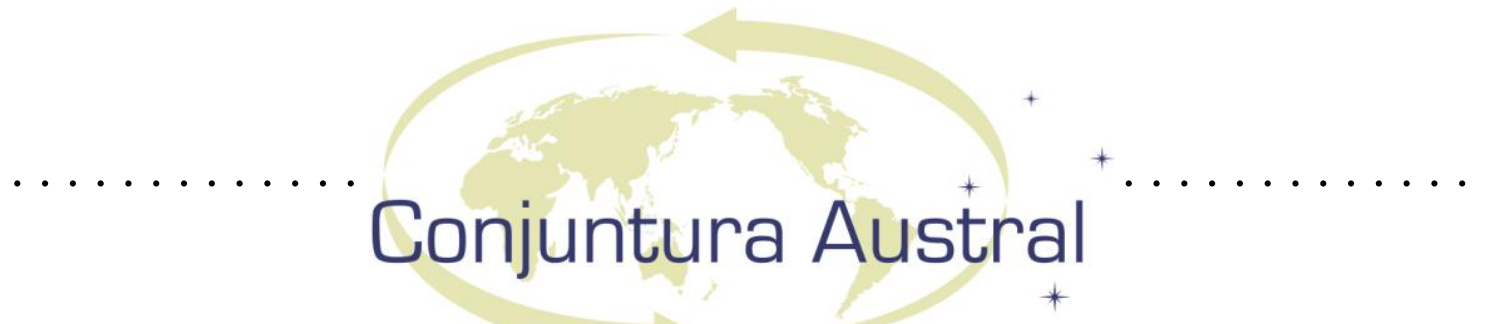

militares e democracia são incompatíveis". (PATRIOTA in KOURLIANDSKY, 2011)Em nota à imprensa de 04 de março de 2011, foi destacado:

O Governo e o povo brasileiros se solidarizam com as eloquentes manifestações das sociedades no mundo árabe em favor da realização de suas justas aspirações e anseios por maior participação nas decisões políticas, em ambiente democrático, com perspectivas de crescimento econômico e inclusão social, capaz de gerar oportunidades de emprego, liberdade de expressão e dignidade humana. (...) O Brasil privilegiará a diplomacia, o diálogo e a negociação no encaminhamento de situações de tensão, em que haja risco de conflagração ou quadro de violência. (...) O Brasil tem mantido consultas permanentes sobre a situação no Norte da África e no Oriente Médio com os demais membros do Conselho de Segurança da ONU e com o Secretário Geral das Nações Unidas. (MRE, 2011a)

Percebe-se aí a ressalva feita pelo Itamaraty da preeminência concedida à diplomacia e ao diálogo. De fato, ao levar-se em consideração a posição assumida pelo Brasil frente ao conflito na Síria, podemos perceber a defesa de tradicionais princípios da diplomacia brasileira: a autodeterminação dos povos, a não intervenção, a solução pacífica de controvérsias, o juridicismo e o multilateralismo.

A primeira nota à imprensa do governo brasileiro sobre a situação na Síria foi de 25 de abril de 2011, período em que as discussões sobre a situação na Líbia - país onde o confronto entre as forças do governo e da oposição se radicalizara - já haviam levado à aprovação de duas resoluções no Conselho de Segurança. A última, de março - na qual o Brasil se absteve, juntamente com Alemanha, Índia, Rússia e China -, aprovou uma zona de exclusão aérea sobre o país e acabou levando à intervenção armada da OTAN.

Assim, em abril, quando os confrontos na Síria apresentaram uma escalada de violência, o governo brasileiro manifestou preocupação, reiterou seu repúdio ao uso da força contra manifestantes desarmados e expressou expectativa de que a crise pudesse ser equacionada pela via do diálogo. (MRE, 2011b) Mais do que isso, ressaltou:

O Governo brasileiro reafirma o entendimento de que a responsabilidade pelo tratamento dos impactos das crises no mundo árabe sobre a paz e segurança internacionais recai sobre o Conselho de Segurança das Nações Unidas e ressalta a importância do papel dos organismos regionais - em particular a Liga dos Estados Árabes e a União Africana - nos esforços de mediação diplomática. (MRE, 2011b)

Essa posição brasileira, de defesa de uma solução pacífica e por meio do diálogo, assim como a ênfase na responsabilidade multilateral pela paz e segurança internacionais, foi mantida durante todo o período. Assim, em agosto de 2011, na 


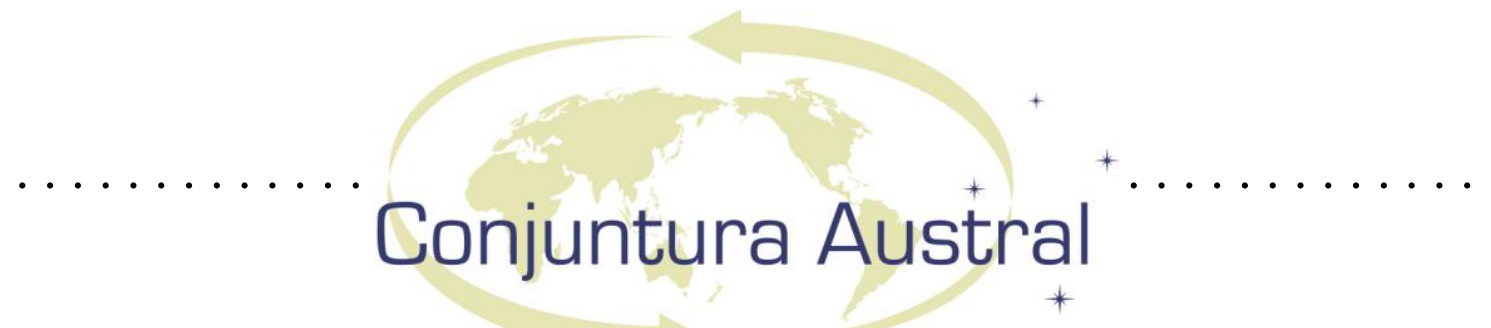

tentativa de uma saída negociada para a crise, o Brasil, juntamente com seus parceiros do IBAS (Índia e África do Sul), enviou uma delegação à Damasco paradebater propostas visando ao fim da violência e à promoção de reformas no país. (MRE, 2011c)

A delegação composta pelo Embaixador EbrahimEbrahim, Vice-Ministro das Relações Internacionais e Cooperação da África do Sul; pelo Embaixador Paulo Cordeiro de Andrade Pinto, Subsecretário-Geral para África e Oriente Médio do Brasil; e pelo Embaixador DilipSinha, Secretário Adjunto para Organizações Internacionais do Ministério dos Negócios Estrangeiros da Índia, foi recebida pelo próprio presidente Bashar Al Assad e pelo Ministro para os Negócios Estrangeiros e Expatriados da República Árabe da Síria,WalidAl-Moualem. Entre os objetivos da missão estavam reforçar a preocupação internacional com as denúncias de violência e apoiar as reformas anunciadas pelo governo sírio, além de lamentar as mortes de civis e pedir o fim imediato da violência e o respeito aos direitos humanos. (MRE, 2011c)

O grupo, que buscava impedir uma intervenção externa, assim como assumir sua responsabilidade como membros do Conselho de Segurança da $\mathrm{ONU}^{5}$, recebeu diversas promessas do governo sírio, como, por exemplo, a suspenção das ações militares e a implantação de reformas democráticas. (MRE, 2011c) No entanto, essas questões não foram cumpridas. Não se pode desmerecer, contudo, a tentativa de uma solução negociada por parte desses países, assim como o fato de os representantes terem sido recebidos pelo próprio Assad, o que denota reconhecimento da sua importância.

Quando da reunião anual da Assembleia Geral da ONU em setembro, a situação não havia melhorado, e a presidente foi enfática em seu discurso de abertura ao falar sobre a "Primavera Árabe".

É preciso que as nações aqui reunidas encontrem uma forma legítima e eficaz de ajudar as sociedades que clamam por reforma, sem retirar de seus cidadãos a condução do processo. Repudiamos com veemência as repressões brutais que vitimam populações civis. Estamos convencidos de que, para a comunidade internacional, o recurso à força deve ser sempre a última alternativa. A busca da paz e da segurança no mundo não pode limitar-se a intervenções em situações extremas.Apoiamos o Secretário-Geral no seu esforço de engajar as Nações Unidas na prevenção de conflitos, por meio do exercício incansável da democracia e da promoção do desenvolvimento. (ROUSSEFF, 2011, grifos meus)

\footnotetext{
${ }^{5}$ Em 2011, os 3 países membros do IBAS ocupavam cadeiras rotativas no CS da ONU.
} 


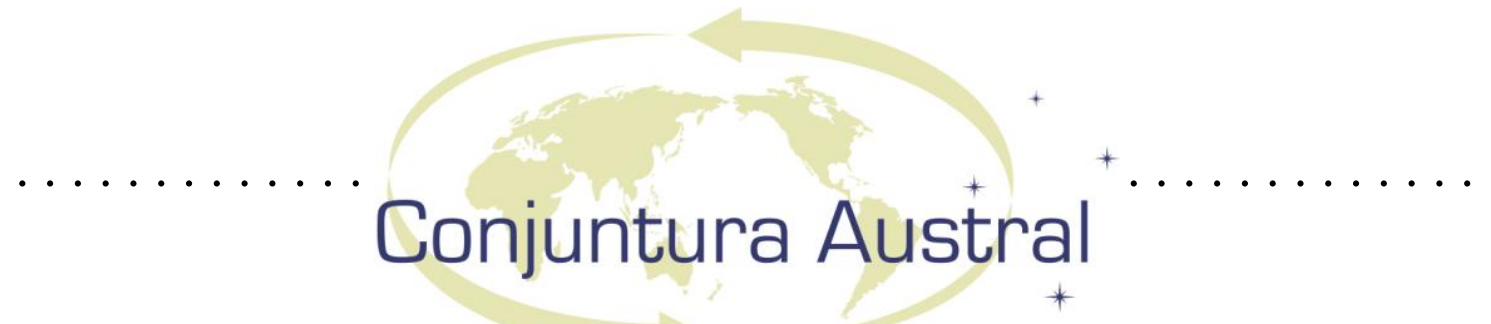

Percebe-se com isso, outro ponto defendido pelo Brasil: o processo de reforma na Síria deve ser conduzido pelos seus cidadãos - e não por ingerência externa. Além disso, a tradicional posição brasileira de correlação entre a promoção do desenvolvimento e a prevenção de conflitos também foi destacada. Mais do que isso,Dilma Roussefffoi crítica em relação a ações unilaterais, sem o aval da ONU; e, sob a égide dos acontecimentos na Líbia, cuja resolução do CS havia sido aprovada com base no conceito de "responsabilidade de proteger", propôs um novo conceito que deveria nortear as ações externas:

\begin{abstract}
O mundo sofre, hoje, as dolorosas consequências de intervenções que agravaram os conflitos, possibilitando a infiltração do terrorismo onde ele não existia, inaugurando novos ciclos de violência, multiplicando os números de vítimas civis.Muito se fala sobre a responsabilidade de proteger, pouco se fala sobre a responsabilidade ao proteger. São conceitos que precisamos amadurecer juntos. Para isso, a atuação do Conselho de Segurança é essencial, e ela será tão mais acertada quanto mais legítimas forem suas decisões, e a legitimidade do próprio Conselho depende, cada dia mais, de sua reforma.(ROUSSEFF, 2011, grifos meus)
\end{abstract}

A responsabilidade ao proteger engloba antes de tudo a ideia de "não causar danos", devendo os resultados da intervenção gerar o mínimo de violência possível. Nas palavras do chanceler Patriota: "seria lamentável, em última análise inaceitável, se uma missão estabelecida sob mandato das Nações Unidas com o objetivo de proteger civis causasse maiores danos do que aqueles que justificaram sua própria criação". (PATRIOTA, 2012)

Dessa feita, na visão dos formuladores brasileiros, os conceitos de "responsabilidade de proteger" e "responsabilidade ao proteger" deveriam evoluir em conjunto, com base em alguns parâmetros e princípios, como a primazia da prevenção; o rigor da comunidade internacional no uso prévio de todos os meios pacíficos disponíveis; e quando o uso da força fosse permitido, a produção do mínimo possível de violência e instabilidade, além de uma ação criteriosa, proporcional e limitada aos objetivos estabelecidos pelo Conselho de Segurança. (PATRIOTA, 2012) O Brasil

\footnotetext{
${ }^{6}$ Conceito adotado no $60^{\circ}$ aniversário da ONU e reconhecimento pelo Documento Final da Cúpula Mundial de 2005. Estabelece a responsabilidade dos Estados de protegerem suas populações em casos de genocídio, crimes de guerra, limpeza étnica e crimes contra a humanidade, colocando sob responsabilidade internacional a ação coletiva, por intermédio da ONU, caso as autoridades nacionais deixem de proteger suas populações.
} 


\section{Conjuntura Austral}

buscava, assim, ao propor esse novo conceito, diminuir os riscos causados à população civil de uma ação armada externa, reconhecendo, de maneira implícita, a necessidade dessa em alguns casos. Nas palavras de Patriota:

Reconhecemos que em alguns casos a comunidade internacional não poderá prevenir, por meios diplomáticos, conflitos armados com violações massivas de direitos humanos da população civil. Ainda assim, devem-se esgotar todos os meios pacíficos para minimizar o impacto sobre civis. (PATRIOTA, 2013).

Mesmo assim, percebe-se que o foco na prevenção e na solução pacífica não foi abandonado. No mesmo artigo em que reconhece que nem sempre os meios diplomáticos serão capazes de proporcionar uma solução para conflitos, o Ministro destaca que a melhor forma de garantir a proteção de civis é pela prevenção.

\footnotetext{
Prevenção de conflitos e resolução pacífica de disputas minimizam o sofrimento de civis. Quando a intervenção militar é autorizada e considerada potencialmente benéfica, a responsabilidade de proteger deve ser acompanhada da responsabilidade ao proteger. [Assim] Em situações excepcionais e extremas em que o uso da força venha a ser autorizado pelo Conselho de Segurança para proteger civis, é necessário garantir que a intervenção militar seja criteriosa, proporcional e estritamente limitada aos objetivos estabelecidos pelas Nações Unidas. (PATRIOTA, 2013)
}

A posição brasileira em relação à Síria, no entanto, assume que não há uma solução militar para a crise e apoia o Plano de Seis Pontos de Annan, lançado em abril de 2012 e que nunca chegou a ser inteiramente cumprido. Os seis pontos, apresentados às autoridades sírias, compreendiam: (i) comprometer-se a trabalhar com o enviado no processo político inclusivo, conduzido pela Síria, para tratar das aspirações legítimas e preocupações do povo sírio; (ii) comprometer-se a deter os combates e alcançar urgentemente o fim da violência armada de todas as formas pelos envolvidos, a fim de proteger os civis e de estabilizar o país, tudo sob a supervisão das Nações Unidas, (iii) garantir o abastecimento oportuno de ajuda humanitária a todas as áreas afetadas pelos combates; aceitar e aplicar uma pausa humanitária diária de 2h, (iv) intensificar o ritmo e o número das libertações dos detidos arbitrariamente, (v) garantir a liberdade de movimento pelo país de jornalistas e a adoção de política não discriminatória de vistos, (vi)respeitar a liberdade de associação e o direito de manifestarem-se pacificamente. (EFE, 2012) 


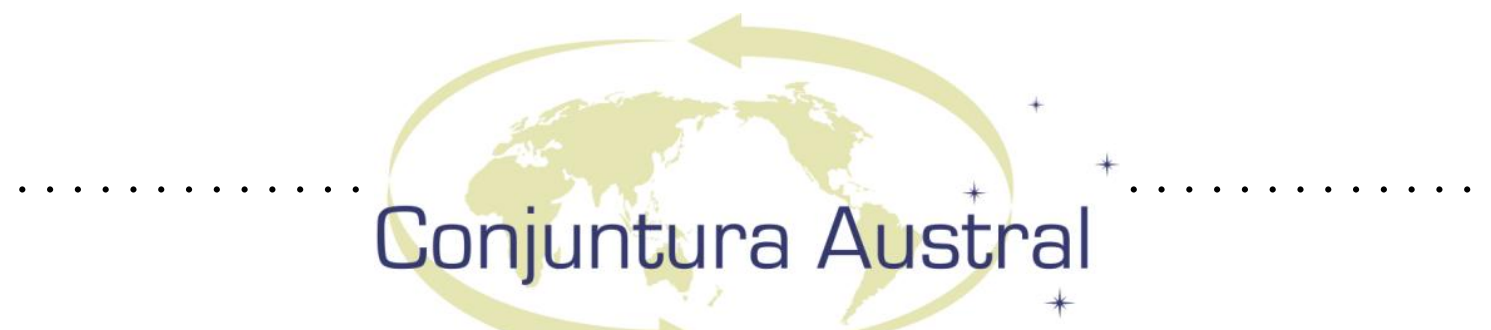

Somando-se aos esforços de Annan, em junho de 2012, reuniu-se pela primeira vez, o Grupo de Ação sobre a Síria, em Genebra, em busca de um consenso internacional para uma transição pacífica no país. Participaram da reunião os ministros das Relações Exteriores dos cinco membros permanentes do CS - EUA, Rússia, China, Grã-Bretanha e França -, do Iraque, do Kuwait e do Qatar, membros da Liga Árabe e da Turquia, assim como a chefe da diplomacia europeia, Catherine Ashton, e o secretáriogeral da ONU, Ban Ki-moon. (FRANCE PRESSE, 2012)

O grupo chegou a um acordosobre os princípios e as diretrizes de uma transição na Síria, divulgado pelo mediador Kofi Annan. De acordo com o Annan, os participantes identificaram as etapas e as medidas a serem tomadas pelas partes para garantir a aplicaçãocompleta do plano de seis pontos e das resoluções 2042 e $2043^{7}$ do Conselho de Segurança. O documento final defendia o estabelecimento de um órgão governamental de transição, que pudesse estabelecer um entorno neutro no qual se desenvolveria a transição. Nesse governo de transição, todos os grupos e segmentos da sociedade deveriam ser permitidos, incluindo membros do regime de Assad, em um processo de diálogo nacional. O passo seguinte seria a redação da Constituição síria, que deveria ser submetida à aprovação popular. *(EFFE, FRANCE PRESSE, 2012)

A partir daí, a posição brasileira foi de apoio ao Grupo de Ação de Genebra e ao Plano de Seis Pontos de Annan. Em debate aberto do Conselho de Segurança sobre a situação no Oriente Médio, em 25 de julho de 2012, a embaixadora brasileira afirmou:

\begin{abstract}
Acompanhamos com angústia e com extrema inquietação a escalada da crise na Síria. Estamos profundamente preocupados ao vermos as dificuldades que este Conselho tem encontrado para enviar uma mensagem unívoca em resposta aos últimos acontecimentos. Um cessar-fogo urgente é imperativo e isso requer um apoio resoluto ao Enviado Especial Conjunto Kofi Annan, ao seu plano de seis pontos e ao Comunicado Final do Grupo de Ação de Genebra. (...) O Brasil apoia a abordagem usada pelo Grupo de Ação e encoraja fortemente o Conselho de Segurança a endossar o Comunicado. Os esforços do Sr. Annan rumo a uma solução negociada e a uma transição política encabeçada pelos sírios continuam a ser a melhor - para não dizer única - possibilidade de evitar o aprofundamento de ciclo de destruição que
\end{abstract}

\footnotetext{
${ }^{7}$ A resolução 2042 é de abril de 2012 e reitera o apoio do CS ao Plano de Annan, assim como autoriza o envio de uma missão preparatória de observadores não militares. A resolução 2043 é de maio do mesmo ano e ressalta a importância do cumprimento do Plano de 6 pontos, nota que o cessar da violência armada foi claramente incompleto e institui, por um período inicial de 90 dias, uma Missão de Supervisão das Nações Unidas na Síria (UNSMIS), no comando de um chefe de Observadores Militares.
} 


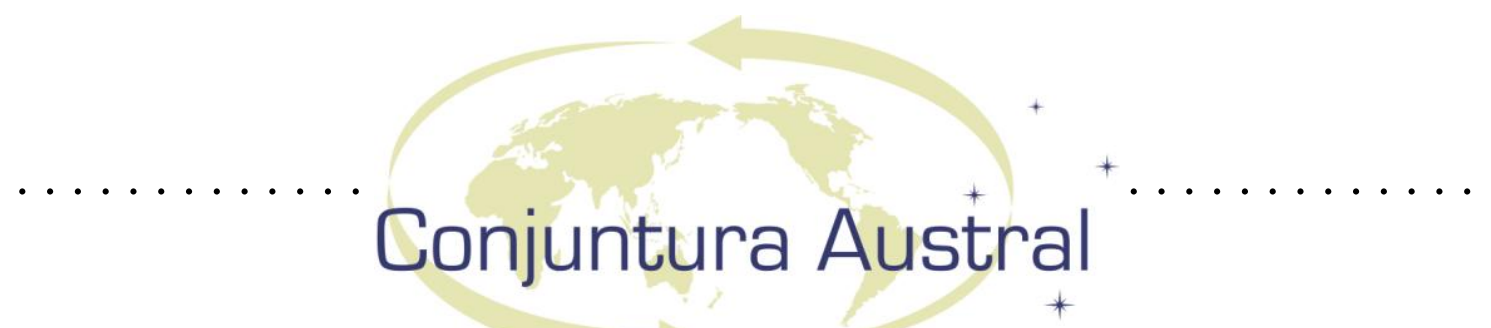

poderá apenas causar mais sofrimento à população síria, gerando fluxos crescentes de refugiados e aumentando o risco de afetar a região como um todo (...). (MRE, 2012)

A atuação brasileira em relação à crise síria também foi bastante ativa no Conselho de Direitos Humanos (CDH) da ONU. Em novembro de 2011, o Conselho aprovou sua primeira resolução de condenação à Síria. O Brasil e mais 120 países votaram a favor da resolução, elaborada pela Grã-Bretanha, França e Alemanha. O texto, que possui caráter de advertência e é um dos principais instrumentos diplomáticos de pressão, apelava ao presidente Bashar Al Assad por um cessar imediato às violações denunciadas no país e condenava veementemente "a continuação grave e sistemática das violações aos direitos humanos pelas autoridades sírias, como execuções arbitrárias, uso excessivo da força e da perseguição e morte de manifestantes e defensores dos direitos humanos.", assim como "detenções arbitrárias, desaparecimentos forçados, tortura e maus tratos de detidos, incluindo crianças". (CARTA CAPITAL, 2011)

No início de junho de 2012, em sessão especial do CDH sobre a Síria, devido à morte de dezenas e ferimento de centenas em aldeia perto de Homs, a embaixadora brasileira destacou mais uma vez, a posição do país de defesa de uma solução negociada, mas de responsabilização dos responsáveis pelos crimes.

O Brasil reafirma seu apoio ao plano de seis pontos do Enviado Especial Kofi Annan e salienta, em particular, a necessidade de um fim imediato do combate e efetiva cessação de todas as formas de violência. (...)Não há solução militar para a atual crise na Síria, e o Governo sírio é o principal responsável por criar as condições necessárias para que o plano de seis pontos possa prosperar. (...) Em conformidade com o nosso apoio a todas as resoluções anteriores sobre abusos de direitos humanos na Síria adotadas por este Conselho, pela Assembleia Geral da ONU e pela Unesco, o Brasil insta a Comissão de Inquérito a investigar as mortes e estabelecer responsabilidades por esses crimes. (MRE, 2012a, grifos meus)

Em sessão do $\mathrm{CDH}$ no final de junho, o Brasil condenou, mais uma vez, a violência, reafirmou que não há solução militar para a crise e que recai sobre o governo sírio a responsabilidade primária pela proteção dos civis e pela garantia das condições para que aviolência cesse, "de modo a permitir o início de um processo político inclusivo, conduzidopelos próprios sírios, com vistas a atender, de forma democrática e efetiva, às aspirações dopovo sírio”. (MRE, 2012b) 


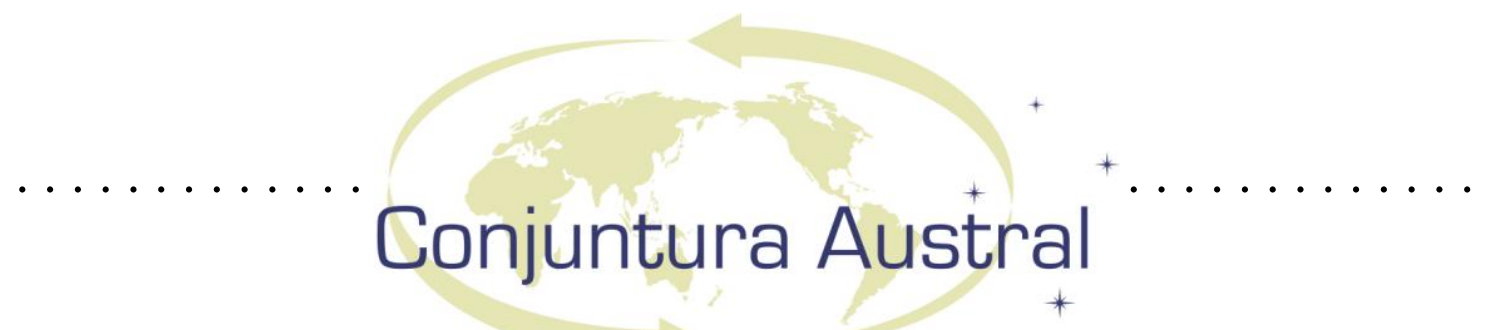

Ainda em defesa de uma solução negociada e contra a escalada militar do conflito, o Brasil votou contra resolução da Assembleia Geral da ONU em maio de 2013. Na justificativa do voto, a embaixadora brasileira reafirmoua necessidade de uma solução negociada, "em conformidade com as disposições do Comunicado de Genebra do Grupo de Ação para a Síria, que continua a ser uma base de consenso para um plano abrangente e eficaz para pôr fim ao conflito".Também destaca os esforços que a ONU deveria empreender para colaborar na "criação de um ambiente propício ao entendimento entre todas as partes sírias", mas não vê como a dita resolução o faria.

\begin{abstract}
Infelizmente, o texto ainda está aquém do que consideramos necessário para uma mensagem da Assembleia Geral que aspire a criar impacto local positivo.O fato de não se encontrar no texto uma conclamação explícita para que não haja uma escalada militar do conflito é injustificável. A Assembleia Geral não pode se esquivar de afirmar claramente que não pode haver solução militar para a crise. A ausência de uma declaração deste tipo enfraquece a confiança no empenho da comunidade internacional para pôr fim ao conflito por meios diplomáticos. A resolução poderia, igualmente, ter incluído importantes averiguações e conclusões feitas pela Comissão Internacional Independente de Inquérito sobre a Síria. A Comissão tem, muitas vezes, chamado a atenção para os "efeitos deletérios do regime de sanções" contra o povo sírio. Recomendou, ademais, que a comunidade internacional contivesse a proliferação e o fornecimento de armas e identificasse suas fontes, tendo em conta as implicações regionais e a respectiva responsabilidade na vizinhança e em outras partes. (...) É hora de criar melhores condições para que as partes negociem (...). Não vemos como a resolução sirva a esse propósito. (MRE, 2013a)
\end{abstract}

Assim, o Brasil se posiciona claramente contra qualquer alternativa que pudesse levar a uma escalada do conflito. Ademais, sua posição contra as sanções - às quais nunca aderiu - também é destacada no enunciado, assim como a crítica ao fornecimento de armas. Torna-se patente que, poucas semanas após, a União Europeia suspenderia o embargo de armas à oposição ao regime de Assad.

Em relação aos últimos desdobramentos do conflito, quando do ataque de armas químicas, próximo a Damasco, em agosto de 2013, o governo brasileiro emitiu nota condenando o "ato hediondo" e destacando a necessidade de esforços concentrados da comunidade internacional para pôr fim à violência no país. Mais uma vez, alega que não há solução militar para o conflito.

O Brasil reitera sua posição de que não existe solução militar para o conflito e recorda seu apoio à convocação de conferência internacional sobre a situação síria. Somente um processo político inclusivo, liderado pelos próprios sírios, como preconizado no Comunicado do Grupo de Ação sobre a 


\section{Conjuntura Austral}

Síria, emitido em 2012, poderá levar à paz e à efetiva proteção da população civil naquele país.Como signatário da Convenção para a Proibição de Armas Químicas, o Brasil é favorável à destruição de todos os arsenais químicos ainda existentes. (MRE, 2013b)

Dessa feita, o Brasil apoiou e saudou o acordo a que chegaram Estados Unidos, Rússia e Síria sobre a destruição das armas químicas desse último, recebendo "com satisfação" a notícia da aprovação pelo Conselho de Segurança da resolução que determinou a eliminação de todas as armas químicas do território da Síria e endossou o processo de paz conduzido pelos sírios. (MRE, 2013c)

Enfim, é possível perceber que o governo brasileiro manteve uma postura constante ao longo do conflito na Síria, mantendo a defesa da necessidade de encontrar uma solução negociada para a crise. De fato, as tradicionais posições brasileiras de solução pacífica, defesa do multilateralismo e não intervenção estão presentes e são patentes na posição brasileira em relação ao conflito sírio. Contudo, desde o envio de delegação do IBAS à Damasco para conversas sobre a crise, o Brasil acabou por não envolver-se de maneira mais direta na questão, preferindo atuar e enfatizar seu ponto de vista nas reuniões da ONU.

\section{Conclusão}

Quando Dilma Rousseff assumiu a presidência da República em janeiro de 2011, o mundo encontrava-se em um dos momentos mais graves da crise financeira internacional; o Mundo Árabe, por sua vez, passava por um momento de mudanças políticas. Milhares saíram às ruas da Tunísia, Egito, Bahrein, Líbia, Síria para pedir mais liberdades civis e políticas.

Na Síria, os protestos que se iniciaram em março de 2011 evoluíram para um grave conflito interno, configurando atualmente, uma guerra civil que já deixou milhares de mortos e milhões de refugiados. A comunidade internacional, por sua vez, empreendeu alguns esforços na tentativa de buscar um consenso, que, até o momento, se revelaram infrutíferos.

Nesse ínterim, o Brasil tem sido bastante coerente e mantido a posição de defesa de uma solução negociada para o conflito, em um processo político conduzido pelos 


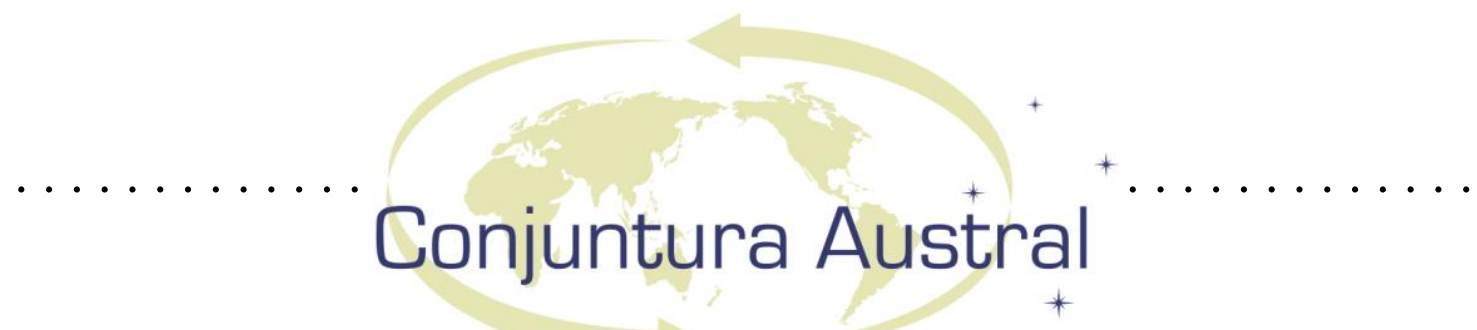

próprios sírios. Mais do que isso, o País condenou tanto a violência que se desenrola na Síria, como a própria inabilidade do Conselho de Segurança da ONU de buscar uma saída para o conflito. Esse último ponto reflete a oposição brasileira a ações externas unilaterais - ou entre grupo de países, fora dos auspícios das Nações Unidas -, assim como permite a ênfase brasileirana necessidade de reforma do órgão.

De maneira geral, pode-se afirmar que, ao longo desses quase três anos de conflito, a posição brasileira face à situação síria respeitou conceitos que regem a ação externa do País há décadas: (i) o multilateralismo - através do apoio à ação da ONU e da Liga Árabe; (ii) a solução pacífica - pela constante reiteração de que não há uma solução militar para o conflito, visto que essa só acarretaria uma escalada da violência; (iii) a autodeterminação dos povos e a não intervenção - o processo de transição deve ser coordenado pelos próprios sírios; e, (iv)um conceito que engloba todos os demais, o juridicismo, ou seja, o respeito às leis internacionais. Um comunicado conjunto dos países do BRICS de novembro de 2011 ilustraa posição brasileira mantida durante o período:

Os Participantes da reunião ressaltaram a legitimidade das aspirações dos
povos da região por maiores direitos políticos e sociais. Concordaram que o
processo de transformação da região criou a necessidade de buscar formas de
responder a crises no OMNA, no marco do direito internacional e somente
por meios pacíficos, sem o recurso à força, por meio do estabelecimento de
um amplo diálogo nacional com o devido respeito à independência, à
integridade territorial e à soberania dos países da região. Rejeitaram a
violência como meio de consecução de objetivos políticos. Enfatizaram a
necessidade de respeito integral aos direitos humanos por todas as partes,
especialmente pelas autoridades, na proteção de civis desarmados. (MRE,
2011d)

A partir daí, pode-se afirmar que a diplomacia brasileira manteve-se coesa durante todo o período do conflito sírio até o momento na defesa de uma solução diplomática e não militar. Mais do que isso, sua posição, que se apoia em princípios historicamente defendidos pelo país, possui apoio de outros importantes atores internacionais - como os países do BRICS e IBAS. A busca pela solução da crise, no entanto, ainda não chegou ao seu fim e, nesse esforço, mais um encontro do Grupo de Ação da Síria - conhecido como Genebra II - foi marcado para novembro de 2013. 


\section{Conjuntura Austral}

\section{REFERÊNCIAS}

ABOUZEID, Rania. Syria's Revolt: How Graffiti Stirred an Uprising. Time world.22 de mar de 2011. Disponível em: $<$ http://content.time.com/time/world/article/0,8599,2060788,00.html>. Acesso em 07/10/13.

ANDERSON, Perry. Explosões em sequência. Piauí. Jun de 2011, ed. 57. Disponível em: <http://revistapiaui.estadao.com.br/edicao-57/tribuna-livre-da-luta-de-classes/ explosoes-em-sequencia>. Acesso em 03/13.

CARTA CAPITAL. Brasil apoia resolução da ONU contra Síria. Carta Capital. 23 de nov de 2011. Disponível em: <http://www.cartacapital.com.br/internacional/brasilapoia-resolucao-da-onu-contra-siria>. Acesso em 08/10/13.

CNN.Syria Civil War Facts.CNN Lybrary.08 de out de 2013.Disponível em: <http://edition.cnn.com/2013/08/27/world/meast/syria-civil-war-fast-facts/index.html>. Acesso em 11/10/13.

EFE. Plano de seis pontos para Síria proposto pelo enviado especial Kofi Annan. 12 de abr de 2012. Disponível em: <http://veja.abril.com.br/noticia/internacional/plano-deseis-pontos-para-siria-proposto-pelo-enviado-especial-kofi-annan> Acesso em 10/10/13

EFE; FRANCE PRESSE. Grupo de Ação sobre a Síria chega a acordo de transição. Veja online. 30 de jun de 2012. Disponível em: <http://veja.abril.com.br/noticia/ internacional/acordo-em-genebra-sobre-principios-da-transicao-na-siria $\rangle$ Acesso em $10 / 11 / 13$

FRANCE PRESSE. Começa reunião do grupo de ação da Síria em Genebra. 30 de jun de 2012. Disponível em: <http://m.g1.globo.com/mundo/noticia/2012/06/comecareuniao-do-grupo-de-acao-sobre-a-siria-em-genebra-1>. Acesso em 11/10/13

KOURLIANDSKY, Jean-Jacques. Lições latino-americanas da crise na Líbia. 29 de ago de 11. Disponível em: <http://www.itamaraty.gov.br/sala-de-imprensa/artigosrelevantes/lecons-latino-americaines-de-la-crise-libyenne-iris-29-08-2011/print-nota> Acesso em 08/10/13

MRE. Notas à imprensa. Vários anos. Disponível em: <http://www.itamaraty.gov.br/ sala-de-imprensa/notas-a-imprensa> Acesso em 10/2013

NEW YORK TIMES. 'Day of Rage' for Syrians Fails to Draw Protesters. New York Times.04 fev de 2011. Disponível em: < http://www.nytimes.com/2011/02/05/ world/middleeast/05syria.html?_r=0> Acesso em 07/10/13 


\section{Conjuntura Austral}

OJEDA, Igor. Diplomacia brasileira sob Dilma e Patriota muda de estilo, mas mantém essência. Opera Mundi. 02 de janeiro de 2013. Disponível em <http://operamundi.uol.com.br/conteudo/reportagens/26165/diplomacia+brasileira+sob + dilma+e+patriota+muda+de+estilo+mas+mantem+essencia.shtml?utm_source $=$ twitter feed\&utm_medium=twitter > Acesso em 05 de janeiro de 2013.

ONU BRASIL. Conflito na Síria. Entenda a Crise. Sem data. Disponível em: <http://www.onu.org.br/siria/> Acesso em 08/10/13

PATRIOTA, Antonio. Brasil negocia ação diplomática junto à Síria. Entrevista in: O Estado de São Paulo. 17 de jul. de 2011. Disponível em: $<$ http://www.itamaraty.gov.br/sala-de-imprensa/discursos-artigos-entrevistas-e-outrascomunicacoes/ministro-estado-relacoes-exteriores/brasil-negocia-acao-diplomaticajunto-a-siria-entrevista-concedida-ao-jornal-o-estado-de-s.-paulo-17-de-julho-de-2011> Acesso em 08/10/13

.Direitos Humanos e Ação Diplomática. Folha de São Paulo.01 de set de 2011b. Disponível em: <http://www.itamaraty.gov.br/sala-de-imprensa/discursosartigos-entrevistas-e-outras-comunicacoes/ministro-estado-relacoes-exteriores $>$ Acesso em $08 / 10 / 13$

. Pronunciamento do Ministro Antonio de Aguiar Patriota em debate sobre Responsabilidade ao Proteger na ONU. 21 de fev de 2012. Disponível em: <www.itamaraty.gov.br> Acesso em 08/10/13

Diplomacia e proteção de civis. O Estado de São Paulo. Disponível em: <www.itamaraty.gov.br> Acesso em 08/10/13

REUTERS. "Síria Assina Convenção Contra Armas Químicas", diz diplomata. http://exame.abril.com.br/mundo/noticias/siria-assina-convencao-contra-armasquimicas-diz-diplomata

ROUSSEFF, Dilma. Discurso da Presidenta da República, Dilma Rousseff, na abertura do Debate Geral da 66 $^{\mathrm{a}}$ Assembleia Geral das Nações Unidas - Nova York/EUA. 2011. Disponível em: <http://www2.planalto.gov.br/imprensa /discursos/discurso-da-presidenta-da-republica-dilma-rousseff-na-abertura-do-debategeral-da-66a-assembleia-geral-das-nacoes-unidas-nova-iorque-eua> Acesso em 06/2013

TERRA. Luta por liberdade revoluciona norte africano e península arábica. Linha do tempo. 2013. Disponível em: $<$ http://www.terra.com.br/noticias/infograficos/protestos-mundo-arabe/> Acesso em $08 / 10 / 13$

Artigo recebido dia 10 de outubro de 2013. Aprovado em 20 de outubro de 2013. 


\title{
Conjuntura Austral
}

\section{RESUMO}

Em janeiro de 2011, quando Dilma Rousseff tomava posse como presidente do Brasil, explodia no Mundo Árabe os protestos das populações, que viriam a ser conhecidos como "Primavera Árabe". Na Síria, as manifestações inicialmente pacíficas evoluíram para um grave conflito interno, chamando a atenção da comunidade internacional. O Brasil, desde o início, foi a favor das aspirações dos povos árabes e em relação à Síria, forte defensor de uma busca de consenso e de uma solução negociada.

\section{PALAVRAS-CHAVE}

Síria; política externa brasileira; Dilma Rousseff.

\begin{abstract}
In January 2011, when Dilma Rousseff took office as Brazilian president, the Arab world saw the explosion of public protests - it was the "Arab Spring". In Syria, the initially peaceful demonstrations evolved to a serious internal conflict, which caught the attention of the international community. Brazil, since the beginning, was a strong advocate of a consensus and a negotiated solution.
\end{abstract}

\section{KEYWORDS}

Syria; Brazilian foreign policy; Dilma Rousseff. 


\title{
Conjuntura Austral
}

\section{LAS MONARQUÍAS DEL CONSEJO DE COOPERACIÓN DEL GOLFO (CCG) Y EL CAMBIO CLIMÁTICO}

\section{Gulf Cooperation Council (GCC) monarchies and climate} change

\author{
Ornela Fabani $^{1}$
}

\section{Introducción}

El Golfo Arábigo ${ }^{2}$, situado al sudoeste de Asia, se presenta como un área de relevancia geoestratégica, no sólo por ser un espacio en el que confluyen tres continentes: Europa, África y Asia, sino también por los importantísimos recursos hidrocarburíferos asequibles en dichos territorios.

Entre los Estados que poseen costas sobre el Golfo se encuentran: Arabia Saudita, Bahrein, Emiratos Árabes Unidos, Kuwait, Omán, Qatar, Irán e Irak. Sin embargo, a los fines de este trabajo, prestaremos particular atención a los seis primeros países que en 1981 conformaron el Consejo de Cooperación de Árabes del Golfo (CCG).

Como ya se adelantó, en términos de recursos, los socios del CCG son ricos en hidrocarburos. Tal es así que estos seis países poseen en su conjunto un cuarto de las reservas probadas de gas natural a nivel mundial y son responsables de tres cuartas partes de las exportaciones y la producción de crudo de la región. Como consecuencia, sus volúmenes de extracción, su escala de producción y su excesivo uso de estos recursos ocasionan graves problemas medioambientales, encontrándose algunos de

\footnotetext{
${ }^{1}$ Licenciada en Relaciones Internacionales, Universidad Nacional de Rosario (UNR). Magíster en Integración y Cooperación Internacional, Universidad Nacional de Rosario (UNR). Doctoranda en Relaciones Internacionales, Universidad Nacional de Rosario (UNR). Becaria del Consejo Nacional de Investigaciones Científicas y Técnicas (CONICET). E-mail: ornela_fabani@ hotmail.com

${ }^{2}$ También denominado Golfo Pérsico por el Estado iraní.
} 


\section{Conjuntura Austral}

estos Estados entre aquellos con los mayores niveles de emisiones de $\mathrm{CO}^{2}$ per cápita a nivel global.

El objetivo del siguiente trabajo es analizar cómo se han posicionado los Estados miembro del bloque frente al cambio climático. Con tal fin se procederá a analizar a algunas características comunes a estos países, entre las cuales se encuentra el carácter monoproductor de sus economías, para luego indagar en los desafíos que el cambio climático presenta para los mismos, la posición que estos han asumido frente al tema en los organismos internacionales, los proyectos que recientemente han impulsado con vistas a afrontar esta problemática, para finalmente hacer un balance respecto a la Cumbre de Manama y al posicionamiento de estos Estados frente a la misma.

\section{Características compartidas por las monarquías del Golfo: la fuerte}

\section{dependencia económica de los hidrocarburos y sus implicancias}

Para comenzar es importante señalar que los Estados que forman parte del CCG poseen un conjunto de características compartidas que han favorecido tanto el acercamiento como las negociaciones entre los mismos en pos de la conformación del citado organismo subregional. Entre estas pueden destacarse, no sólo su proximidad geográfica, sino también la existencia de una lengua común: el árabe. Por otra parte, estos Estados también detentan una religión compartida y una cultura que se asemeja en muchos aspectos, precisamente por profesar la mayoría de los habitantes de estos países la religión islámica. En el plano político cabe señalar que todos los miembros del CCG adhieren a la forma de gobierno monárquica. En estos países la figura del Rey desempeña funciones propias no sólo del poder ejecutivo sino también del legislativo y ejerce, a su vez, cuanto menos una fuerte influencia en materia judicial. Es propio de estos sistemas una fuerte centralización del poder en torno a la familia real, cuyos miembros suelen detentar altos cargos en distintos ministerios y reparticiones públicas. En términos económicos, los seis Estados poseen amplias reservas de hidrocarburos lo cual ha favorecido el desarrollo de economías rentistas, monoproductoras (Fabani, 2012). 


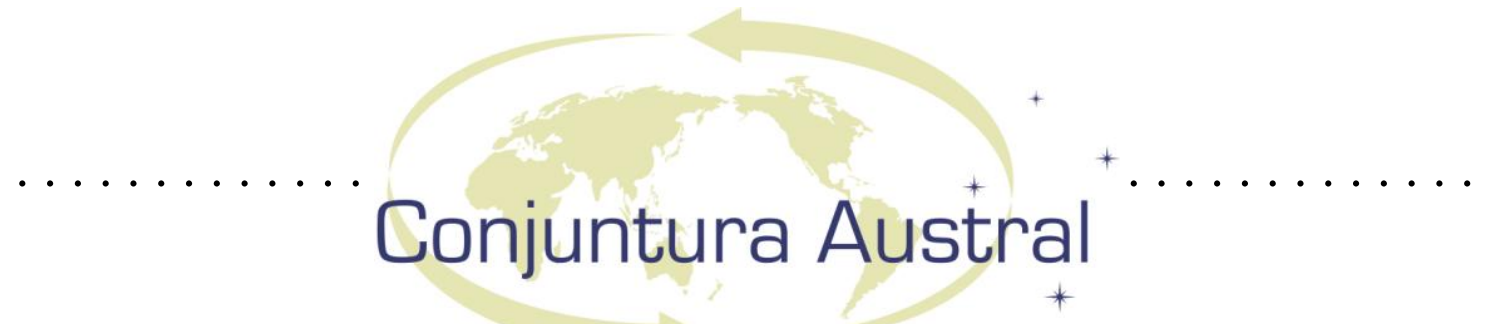

A lo fines de comprender cabalmente la magnitud de los recursos allí disponibles ha de tenerse en cuenta que más de la mitad de las reservas internacionales de crudo están ubicadas en Medio Oriente. En particular, los Estados miembros del bloque son responsables del $75 \%$ de las exportaciones y la producción de esta región y poseen alrededor del $65 \%$ de las reservas de Medio Oriente (Garralda, L'Hotellerie Fallois, 2008). Aún más, los Estados parte del CCG también poseen grandes reservas de gas natural. Tal es así que estos seis países controlan conjuntamente el 23\% de las reservas probadas a nivel mundial (The Economist Intelligence Unit, 2010).

Sin ir más lejos, Arabia Saudita cuenta con aproximadamente el $4 \%$ de las reservadas probadas de gas natural y el $20 \%$ de las reservas probadas de crudo del mundo; convirtiéndose no sólo en el país con mayores reservas sino también en el principal productor (Oficina Económica y Comercial de España en Riad, 2010: 11). En el caso de Qatar, el emirato cuenta con alrededor de un 14\% de las reservas mundiales de gas natural, erigiéndose como la tercera gran reserva, seguido por Arabia Saudita y por Emiratos Árabes, en el cuarto y quinto lugar, respectivamente (Global Investment House, 2008). Como correlato, tanto en Arabia Saudita como en Qatar y en los restantes Estados miembros del CCG, los hidrocarburos son responsables de un amplio porcentaje del PBI, de los ingresos por exportaciones y asimismo de la renta de estos gobiernos (Bueno, Fabani, Fernandez, 2011).

De cualquier manera, es necesario señalar que la amplia disponibilidad de estos recursos así como también la alta rentabilidad de su explotación ha tenido implicancias diversas para estos países. Por un lado, gracias a las ventajas económicas que ha representado la extracción de hidrocarburos, los seis socios del CCG han transitado en las últimas décadas un fuerte proceso de crecimiento económico que ha derivado en: el desarrollo de infraestructura, la mejora de los sistemas de salud, el incremento del empleo en el sector público, importantes subsidios a los servicios, e incluso la posibilidad de que algunos de estos países se cuenten entre aquellos con los mayores niveles de PBI per cápita a nivel internacional ${ }^{3}$. Estas prestaciones han tenido un rol

\footnotetext{
${ }^{3}$ En 2011, con un PBI per cápita que giro en tono al 14\%, Qatar se convirtió en el país con el mayor PBI per cápita a nivel internacional.
} 


\section{Conjuntura Austral}

central en lo que atañe al contrato social vigente entre las monarquías del Golfo y sus ciudadanos (Luomi, 2013).

Sucede que, en estos países los ciudadanos tradicionalmente se han visto privados de la participación política, existiendo un bajo ejercicio de mecanismos democráticos. Por ende, ante la persistencia de sistemas políticos cerrados, la bonanza y los beneficios económicos han sido centrales para favorecer la aceptación por parte de la población de los regímenes vigentes (Fabani, 2012); la calma, que no obstante se ha visto sacudida como producto de las manifestaciones que tuvieron lugar el marco del fenómeno que se dio a llamar "primavera árabe".

Ahora bien, como contrapartida, el uso y abuso de los hidrocarburos también ha implicado una fuerte dependencia económica de los seis socios de la explotación de éstos recursos y como correlato su escasa diversificación económica; volviéndolos sumamente vulnerables a la volatilidad de los precios internacionales de los mismos (Bueno, Fabani, Fernandez, 2011).

Además, si bien los países del Golfo no se encuentran entre aquellos con las mayores emisiones de $\mathrm{CO}^{2}$ totales, no puede pasarse por alto que los mismos sí se cuentan entre los responsables de la mayores emisiones per cápita a nivel global. En efecto, los países miembros del CCG emiten de forma conjunta 26,3 toneladas de $\mathrm{CO}^{2}$ per cápita al año, seis veces por encima del promedio global. (Althus, 2012: 2). Este elevado nivel de emisiones se encuentra íntimamente vinculado con: la extracción y producción de hidrocarburos, el alto nivel adquisitivo de gran parte de los ciudadanos, el amplio nivel de consumo de recursos, favorecido por las políticas de subsidio a los servicios públicos que han introducido las monarquías del Golfo, y asimismo con la baja intensidad demográfica de sus territorios.

Principales desafíos en términos medio ambientales que enfrentan las monarquías del CCG

Las monarquías del Golfo se caracterizan por la aridez de su clima, las temperaturas extremas, sus suelos frágiles, y su escasa vegetación, en tierras desérticas. En esta región las lluvias son muy escasas, lo que sumado a las condiciones del terreno 


\section{Conjuntura Austral}

repercute en la posibilidad de un desarrollo agrícola. Más preocupante aún es que todos estos países poseen escasas reservas de agua dulce. Sin embargo, los casos más preocupantes son los de Kuwait, Emiratos Árabes y Qatar que enfrentan una escasez absoluta de agua (Luomi, 2011: 252) ${ }^{4}$. No obstante, hasta el momento estos países han podido sortear la difícil situación que se les presenta recurriendo a la desalinización. Un proceso costoso e intensivo en energía que paradójicamente gracias a los recursos disponibles en estos países les ha permitido a las monarquías del Golfo gozar de altos niveles de consumo (Luomi, 2011: 252).

De acuerdo con el Panel Intergubernamental de Expertos Contra el Cambio Climático (IPCC) se espera que hacia mediados de siglo las temperaturas en Medio Oriente suban entre $2.5^{\circ}$ y $3.7^{\circ}$ en verano, y entre $2.0^{\circ}$ y $3.1^{\circ}$ en invierno, en relación a los niveles propios de la década del noventa. Como consecuencia, en esta zona se incrementarán las sequias y mermarán más aún las reservas de agua dulce; tornándose aún más difícil la subsistencia a raíz de que incluso las precipitaciones mermarán en un $30 \%$, con sus evidentes consecuencias sobre la capacidad de producir alimentos. Esto sin considerar el crecimiento del nivel del mar y el ingreso de agua salada que se espera en las próximas décadas. De hecho, Bahrein se ubica en el undécimo puesto en el Índice de Cambio Climático, corriendo peligro de desaparecer bajo el agua a medida que suba el nivel del mar. Al igual que Bahrein, Kuwait y Qatar también están catalogados como países con "vulnerabilidad extrema" según el índice Maplecroft. Mientras que Omán, Emiratos Árabes y Arabia Saudita se encuentran bajo la categoría de "vulnerabilidad elevada" (Raouf, 2010/2011: 28).

En virtud de lo hasta aquí señalado, los miembros del CCG tarde o temprano, en mayor o en menor medida, deberán afrontar inconvenientes vinculados con la seguridad del agua y los alimentos. A esto se agregan dificultades en cuanto a la seguridad energética. Tres problemas vinculados entre sí ya que, como previamente se ha señalado, para poder paliar el difícil de agua estos países recurren a la desalinización de agua de mar, proceso que requiere de importantes cantidades de energía. Asimismo gran

\footnotetext{
${ }^{4}$ Afrontan escasez absoluta de agua aquellos países que disponen de menos de $500 \mathrm{~m}^{3}$ de agua fresca renovable por persona por año.
} 


\section{Conjuntura Austral}

parte del agua que se obtiene a raíz de este procedimiento es utilizada para la agricultura, si bien estos países no son eficientes en términos agrícolas. La pregunta que emerge es ¿qué harán estos países cuando desaparezcan sus enormes reservas de hidrocarburos y encuentren dificultades para poder comprar, producir sus alimentos, o hacerse de agua potable?

La evolución de la posición de los Estados del CCG frente al cambio climático en los foros medio ambientales

En lo que respecta al posicionamiento que los Estados miembros del CCG han asumido frente al cambio climático es menester destacar que, aunque no todos los socios del organismo son parte de la Organización de Países Exportadores de Petróleo $(\mathrm{OPEP})^{5}$, estos al igual que el resto de sus vecinos árabes han tendido a seguir la línea de esta organización, y de quien ha fungido como su líder, Arabia Saudita.

La política de la OPEP bajo el liderazgo saudí ha tenido un carácter obstruccionista en el marco de las conferencias de Naciones Unidas sobre cambio climático. Este argumento se fundamenta en la implementación de demandas y tácticas que han perseguido el objetivo de ralentizar la protección climática y las negociaciones sobre reducción de emisiones, para de esta forma proteger el status del petróleo en la economía global. Esto se explica en virtud de que, como ya se ha señalado, tanto Arabia Saudita como los restantes países miembros del CCG tienen una fuerte dependencia económica de sus ventas de hidrocarburos. Por ende, una disminución en el consumo de energía, o incluso en la producción de hidrocarburos, seguramente traería aparejado una disminución de sus ingresos que, como ya se ha puesto de manifiesto, resultan vitales para la supervivencia misma de los seis regímenes del Golfo (Luomi, 2011: 255-256).

En esta línea, desde el inicio de las negociaciones en torno a la Convención Marco de Naciones Unidas sobre Cambio Climático (CMNUCC), la OPEP ha evitado asumir compromisos vinculantes en lo relativo a reducciones cuantitativas específicas en las emisiones de carbono, a ser implementadas dentro de un período preestablecido. A la par que ha subrayado la responsabilidad primaria de los países industrializados

\footnotetext{
${ }^{5}$ Omán y Bahrein se encuentran fuera de la organización.
} 


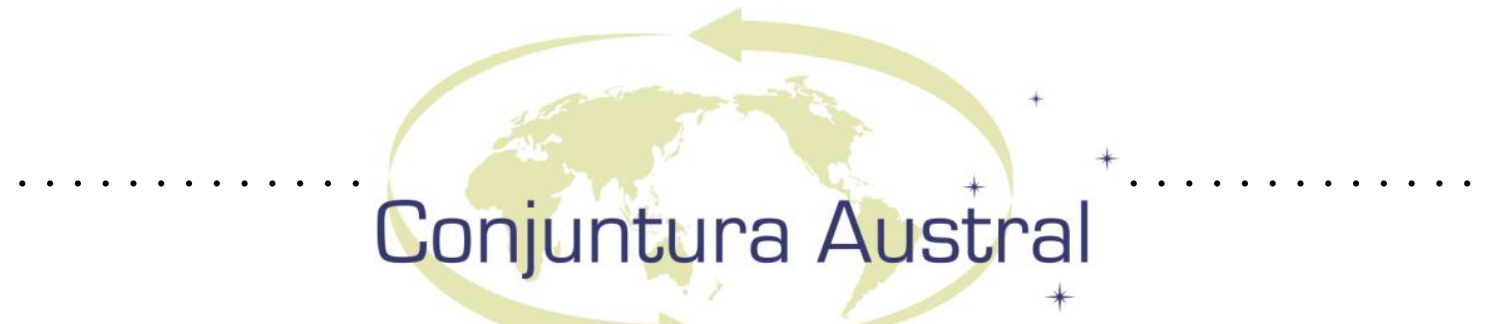

respecto a dichas emisiones. Los miembros de la OPEP, en tanto partes del G-77, se encontraron entre los promotores de la adopción del principio "responsabilidades comunes pero diferenciadas" que luego derivó en la diferenciación entre países del Anexo I y países que no pertenecen al Anexo I. Como correlato, durante las negociaciones en el marco de la CMNUCC, estos Estados pujaron por la introducción del artículo 4.8 y su inciso $(\mathrm{h})^{6}$. Un artículo que insta a una completa consideración de las necesidades y preocupaciones de los países cuyas economías son altamente dependientes de los ingresos generados por la explotación de hidrocarburos. Finalmente, es importante recordar que en los orígenes de este debate estos Estados incluso se permitieron dudar sobre la evidencia científica en torno al cambio climático y sus derivaciones (Chatman House, 2005: 7).

A su vez, tras la segunda Conferencia de Partes (COP) del CMNUCC los países exportadores de petróleo han impulsado la idea de que es necesario el establecimiento de un Fondo de Compensación Económica, una posición que luego apoyaron el conjunto de los Estados miembros del G-77. Básicamente aquello que han defendido estas naciones es que las economías de los países en desarrollo, y particularmente aquellas que tienen una fuerte dependencia económica de los hidrocarburos, serán aquellas que en mayor medida sufrirán los costes de una disminución de emisiones, en virtud de lo cual han reclamado dicha compensación. De igual modo, han pujado por la introducción de los artículos 2.3 y 3.14 del Protocolo de Kyoto, que instan a los países del Anexo I a cumplir con sus objetivos en términos de emisión de forma tal de minimizar el impacto económico, social y ambiental adverso sobre los países en desarrollo (Chatman House, 2005: 7).

\footnotetext{
6 "Al llevar a la práctica los compromisos a que se refiere este artículo, las Partes estudiarán a fondo las medidas que sea necesario tomar en virtud de la Convención, inclusive medidas relacionadas con la financiación, los seguros y la transferencia de tecnología, para atender a las necesidades y preocupaciones específicas de las Partes que son países en desarrollo derivadas de los efectos adversos del cambio climático o del impacto de la aplicación de medidas de respuesta, en especial de los países siguientes:

h) Los países cuyas economías dependen en gran medida de los ingresos generados por la producción, el procesamiento y la exportación de combustibles fósiles y productos asociados de energía intensiva, o de su consumo".
} 


\section{Conjuntura Austral}

Por otra parte, acompañando la posición saudí y de la OPEC, los miembros del CCG se encontraron entre aquellos que defendieron el criterio del consenso, y no el de la mayoría, para la adopción de decisiones en el marco del Protocolo de Kyoto, elemento que permitió a estas naciones mantener su poder de veto que, por otro lado, han utilizado en reiteradas oportunidades frenando las negociaciones (Chatman House, 2005: 7).

A posteriori, en la Conferencia de Marrakech de 2001, estos países lograron influir sobre los términos de referencia del Fondo Especial para el Cambio Climático, lo que permitió incluir actividades vinculadas a la asistencia a los países en desarrollo en pos de la diversificación de sus economías. Desde entonces la cuestión de apoyar económicamente la diversificación económica de los países en desarrollo ha sido objeto de múltiples debates (Chatman House, 2005: 8).

También en esta línea, los miembros de OPEC han bregado por obtener, de parte de los países desarrollados, asistencia para adaptarse al impacto negativo de las políticas internacionales y a las medidas para mitigar el cambio climático, y han demandado la transferencia de tecnologías limpias, particularmente para captura y almacenamiento de carbono (Luomi, 2011: 256).

Ahora bien, en los últimos años, en los países de CCG, parece haber mayor interés respecto a la problemática medioambiental, lo cual se evidencia en la incorporación de este tema en agenda, y se plasma en una evolución hacia posturas más moderadas en las negociaciones sobre cambio climático.

En esta línea cabe mencionar que, en 2009, Emiratos fue escogido para ser sede de la Agencia Internacional de la Energía Renovable. Además, en 2010, creó un Directorio de Energía y Cambio Climático, y en la COP que tuvo lugar dicho año impulsó la decisión de incluir al Mecanismo de Captura y Almacenamiento de Carbono como un tipo de proyecto bajo el Mecanismo de Desarrollo Limpio, tomando distancias de las posiciones más controversiales de la OPEP. Qatar, por su parte, se postuló para ser sede de la COP que finalmente tuvo lugar en Doha en 2012. Mientras que, en Arabia Saudita, el Ministro de Petróleo del Reino sorprendió al declarar públicamente que el cambio climático se encontraba "entre las preocupaciones más urgentes de la 


\section{Conjuntura Austral}

humanidad". Al tiempo, Riad cambiaba a quien había sido su negociador desde el inicio de las negociaciones de la CMNUCC, Mohamed Al Sabban, famoso por su intransigencia (Michelowa, Luomi, 2012: 7).

$\mathrm{Al}$ respecto, hay quienes parecen creer que este cambio de perspectiva de las monarquías del Golfo frente a la cuestión climática es producto de una verdadera concientización en relación a esta problemática (Raouf, 2010/2011). Otros analistas destacan aquello que mueve a las mismas es meramente el hecho de constatar la escasez de sus recursos, la merma de sus reservas, y los costos de oportunidad que derivan del alto consumo doméstico frente a la exportación o utilización a nivel industrial de los hidrocarburos (Mills, 2011). Asimismo están quienes asocian estos cambios con una estrategia de branding, particularmente de Qatar, Emiratos Árabes y Arabia Saudita, asociada a su búsqueda de prestigio y de posicionarse en el escenario internacional (Luomi, 2009; Michelowa, Luomi, 2012: 7).

Ahora bien, lo cierto es que más allá de cuál sea su motivación, estos países que aún tienen una matriz económica y productiva que se sustenta en los hidrocarburos, en los últimos años han dado pasos en pos de la diversificación económica, y de promover políticas sustentables.

\section{Avances hacia la diversificación económica y una economía sustentable}

De acuerdo con un informe del Banco Samba (2010: 1) las estructuras de las economías del CCG paulatinamente están cambiando, evidenciándose las transformaciones más importantes en Bahrein y Emiratos Árabes.

En torno al primero, Bahrein paulatinamente se ha constituido en un importante centro financiero, convirtiéndose en sede de un gran número de bancos extranjeros. Allí también se han ido incrementados las inversiones en transporte y otros servicios y ha sido importante el desarrollo del turismo regional. Si bien este último ha mermado como producto de las protestas que hace ya más de dos años tienen lugar en el reino. Emiratos Árabes también se ha convertido en un destino elegido por el turismo, en este caso internacional. Asimismo, este país se ha transformado en un importante centro económico, comercial y financiero. Impulsado en parte por todo este desarrollo, también 


\section{Conjuntura Austral}

existió un auge de la construcción que en cierta medida se vio frenado como producto de la crisis financiera internacional. También Qatar ha impulsado el desarrollo de diversos sectores, nuevamente: el turismo, la construcción, el transporte y las finanzas (Sturm y otros, 2008: 19).

Además de estos pasos hacia una diversificación de sus economías los países del Golfo vienen desarrollando proyectos asociados con una economía sustentable. Sin lugar a dudas el más publicitado de los mismos es Masdar City, en Emiratos Árabes, que apuesta a la creación de la ciudad con la menor huella ecológica. Entre otros avances que han tenido por escenario a Emiratos vale mencionar que allí abrió, en 2004, la primera planta de energía eólica del Golfo. Asimismo, Emiratos acoge la mayor planta termosolar en operación en el mundo, Shams 1, con capacidad para producir 100 megavatios (Espinosa, 2013).

$\mathrm{Al}$ respecto, los socios del $\mathrm{CCG}$ han anunciado el desarrollo de múltiples proyecto vinculados a la energía solar, que emerge como una energía renovable, como una energía alternativa a la quema de hidrocarburos; siendo esta técnica y económicamente eficiente puesto que la exposición solar directa media a la luz solar es alta en la zona (Raouf, 2010/2011: 26).

Por su lado, Arabia Saudita ha realizado importantes inversiones en investigación y desarrollo en torno a diversos proyectos vinculados con dicha energía, incluyéndose plantas de desalinización y sistemas de refrigeración que funcionan a base de energía solar. Además, se planifica construir una gran planta de energía solar, así como también 16 reactores nucleares para 2030. También Qatar ha dado a conocer planes para desarrollar su primera planta de energía solar que se apunta a que produzca entre 150-200 megavatios. Mientras que en Bahrein se han realizado experiencias para el desarrollo de la energía eólica y allí, al igual que en Omán, se utiliza la energía solar para alimentar unidades de osmosis inversa (Raouf, 2010/2011: 26). Todos proyectos que apuntan a una complementariedad energética.

Ahora bien, más allá de estos avances, un elemento central sobre el cual no se ha trabajado se relaciona con el recorte de los subsidios; prestaciones que predisponen a los habitantes de estos territorios a un amplio consumo de recursos, con su correlato en 


\section{Conjuntura Austral}

términos de emisiones. Actualmente apuntar a una reducción de los mismos deviene tan necesario como complejo, aún más en aquellos Estados que recientemente han debido afrontar fuertes protestas.

\section{La Cumbre de Doha}

En el marco de su estrategia de branding y de su búsqueda por ganar visibilidad, prestigio internacional, e incluso cierto protagonismo en el escenario regional, Qatar se ha postulado para convertirse en sede de diversos eventos deportivos, encuentros y conferencias de mayor relevancia en el plano internacional (Despite shaky start, Qatar largely praised for hosting UN climate talks, 2012). En esta línea se inscribe su postulación como sede de la COP 18, la segunda que tuvo lugar en Medio Oriente luego de una primera experiencia en Marrakech en 2001. Ahora bien lo cierto es que, a más de una década de aquel encuentro, los países miembros de la comunidad internacional siguen evitando asumir compromisos concretos en pos de mitigar el cambio climático.

En lo que respecta a la Cumbre de Doha, tras haberse propuesto en Durban la extensión por un segundo período del Protocolo de Kyoto, éste pudo ser lanzado a tiempo, aunque con un día de retraso. Mientras tanto, otro objetivo de este encuentro residió en comenzar a trabajar en pos de edificar un nuevo régimen climático, que debería adoptarse en 2015 y entrar en funcionamiento en 2020 (La Cumbre de Doha finaliza con escasos acuerdos y polémica, 2012). No obstante, los avances en este sentido fueron escasos.

Vale mencionar que esta segunda fase, a diferencia del nuevo régimen climático que será obligatorio para todas las partes de la CNUCC, sólo obliga a los Estados firmantes. En este caso los países de la Unión Europea, Australia, Noruega y Suiza, puesto que otros participantes en la primera etapa decidieron hacerse a un lado en la segunda. Tal es el caso de Japón, Rusia, Canadá y Nueva Zelandia. Si a esto sumamos que países tales como Estados Unidos, China o India, que se caracterizan por su alto nivel de emisiones no están obligados a reducir las mismas, ya sea por no haber ratificado el Protocolo o por no estar obligados a ello por ser considerados países en 


\section{Conjuntura Austral}

vías de desarrollo, el acuerdo sólo cubre un 15\% de las emisiones globales (La Cumbre de Doha finaliza con escasos acuerdos y polémica, 2012).

Un aspecto positivo a destacar como resultado de esta Cumbre está dado por la decisión de establecer "un mecanismo internacional que incluya funciones y modalidades para hacer frente a las pérdidas y daños" en los países en desarrollo más vulnerables al cambio climático. Sin embargo, lejos del pesimismo, en función de las dificultades que se han hecho presentes a la hora de encontrar financiamiento para las acciones de adaptación y mitigación, y los debates en torno al Fondo Verde para el Clima, parece poco probable que a fututo aparezcan los recursos necesario para hacer frente a estos desafíos.

En lo que atañe a la posición asumida por los socios del CCG en este encuentro, hay quienes valoran su retórica favorable a impulsar un acuerdo y al inicio de la segunda fase de Kyoto. Además, cabe destacar que en el marco del encuentro Arabia Saudita, Emirato Árabes, Qatar y Bahrein realizaron una presentación informal manifestando su disposición a diversificar sus economías, asumir compromisos en términos de reducción de emisiones, tomar medidas de adaptación frente al cambio climático y en pos de luchar contra las consecuencias del mismo sobre sus economías (Despite shaky start, Qatar largely praised for hosting UN climate talks, 2012). Este gesto también evidencia un cambio de actitud de estos países. No obstante, en virtud de la responsabilidad de estos Estados por sus altas emisiones per cápita podría esperarse una mayor predisposición de los mismos, un mayor esfuerzo en la solución de un problema que ellos mismos han contribuido a generar.

\section{Conclusión}

Los países miembros del CCG del Golfo se encuentran entre los grandes productores de crudo y gas natural a nivel internacional. Gracias a sus enormes reservas de estos recursos estos países han desarrollado economías rentistas monoproductoras de hidrocarburos.

En base al rol que dichos recursos detentan en estas economías los países del bloque, bajo la dirección saudí, han asumido a través del tiempo una posición 


\section{Conjuntura Austral}

obstruccionista en las distintas conferencias de Naciones Unidas sobre cambio climático. Sin embargo, en los últimos años las monarquías del Golfo han ido virando hacia posiciones más moderadas en el marco de dichos encuentros, a la par que han dado pasos hacia la diversificación de sus economías y desarrollado diversos proyectos asociados a energías alternativas, particularmente la solar, apuntando a la complementariedad de su matriz energética.

En este sentido, todo indica que los Estados parte del CCG mediante sus acciones y políticas comienzan a reconocer la inexorabilidad de una economía baja en carbono a nivel global empezando a actuar en consecuencia. Esto como producto de las presiones de la comunidad internacional. Asimismo, del intento de algunos de ellos de mejorar su imagen y así ganar prestigio en el escenario global. Y por último, aunque no menos importante, de reconocerse el carácter finito de sus recursos y los costos de oportunidad que traen aparejados sus amplios niveles de consumo. De esta forma, si bien estas economías siguen teniendo una matriz económica y productiva fuertemente ligada a los hidrocarburos el pragmatismo las ha impulsado en los últimos años a promover políticas sustentables.

\section{REFERÊNCIAS}

ALTHUS, Judith (2012): "COP in Qatar: Between fossil of the day and best green practice”, Friederich Eber Stiftung, november. Disponible en: http://library.fes.de/pdffiles/iez/global/09502.pdf

BUENO, Pilar; Fabani, Ornela; Fernández Alonso, José (2011): “Ambiente, energía y democracia en la región del Golfo Pérsico. Análisis de un dilema de difícil solución”, Anuario del Instituto de Relaciones Internacionales, Instituto de Relaciones Internacionales, Universidad Nacional de La Plata (UNLP).

Chatman House (2005): “OPEC and climate change", Royal Institute of International Affairs. Disponible en: <kms1.isn.ethz.ch/.../en/OPEC_Climate_Change.pdf.> 


\section{Conjuntura Austral}

"Despite shaky start, Qatar largely praised for hosting UN climate talks" (2012), Foxnews, United States, 10/12/12. Disponible en: <http://www.foxnews.com/world/2012/12/10/despite-shaky-start-qatar-largely-praisedfor-hosting-un-climate-talks/>

ESPINOSA, Ángeles (2013): "Espejos que exprimen el desierto", El País, España, 24/03/2013. Disponible en: http://economia.elpais.com/economia/2013/03/22/actualidad/1363963218_977506.html

FABANI, Ornela (2012): "El Consejo de Cooperación de Estados Árabes del Golfo: un análisis de su evolución a 30 años de su conformación", Editorial Académica Española, Colección CERIR, Alemania.

GARRALDA, José María Serena, L'Hotelleire Fallois, Pilar (2008): "Petróleo y flujos financieros internacionales: el caso de las economías del Golfo", Economía de la Energía, $\mathrm{N}^{\circ}$ 842, mayo - junio. Disponible en: <http://www.revistasice.com/cms revistasICE/pdfs/ICE_842_9-27_2C0D6B61EC3433891A64E5935E7FFAE5.pdf.>

Global Investment House (2008): "GCC natural gas sector - Dawn of the gas era!", Global Research, may. Disponible en: <http://www.gulfbase.com/site/interface/ SpecialReport/GCC\%20Natural\%20Gas\%2031052008.pdf>. Fecha de consulta: mayo 2011.

"La Cumbre de Doha finaliza con escasos acuerdos y polémica" (2012), Euronews, 08/12/12. Disponible en: <http://es.euronews.com/2012/12/08/la-cumbre-de-dohafinaliza-con-escasos-acuerdos-y-polemica/ $>$

Luomi, Mari (2009): “Abu Dhabi's alternative-energy initiatives: seizing climate-change opportunities", Middle East Policy. Disponible en: <http://www.mepc.org/journal/ middle-east-policy-archives/abu-dhabis-alternative-energy-initiatives-seizing-climatechange-opportunities>

Luomi (2011): "Gulf of Interest: Why Oil Still Dominates Middle Eastern Climate Politics, Journal of Arabian Studies: Arabia, the Gulf, and the Red Sea", Center for International and Regional Studies, Georgetown University School of Foreign Service, Qatar. Disponible en: <http://www.tandfonline.com/doi/pdf/10.1080/ 21534764.2011.628499>

Luomi, Mari (2012): "Gulf of interest: Why oil still dominates Middle Eastern climate politics", Journal of Arabian Studies, december. Disponible en: <http://www.tandfonline.com/doi/pdf/10.1080/21534764.2011.628499> 


\section{Conjuntura Austral}

Luomi, Mari (2013): The Gulf Monarchies and Climate Change: Abu Dhabi and Qatar in an Era of Natural Unsustainability, C Hurst \& Co Publishers Ltd, London.

Michelowa, Luomi (2012): "From climate antagonism to low carbon protagonists?", FNI Climate Policy Perspectives, 6, october. Disponible en: <http://fni.no/ doc\&pdf/FNI-Climate-Policy-Perspectives-6.pdf>

Mills, Robin (2011): "Doha climate talks will turn spotlight on Gulf countries", The National, United Arab Emirates, 06/12/2011. Disponible en: $<$ http://www.thenational.ae/business/industry-insights/energy/doha-climate-talks-willturn-spotlight-on-gulf-countries $>$

Oficina Económica y Comercial de España en Riad (2010): "Guía País: Arabia Saudita". Disponible en: <http://www.oficinascomerciales.es/icex/cda/controller /pageOfecomes/0,5310,5280449_5296122_5287111_4322454_SA,00.html>

Raouf, Mohamed: "El CCG se pasa a la energía verde", Afkar/Ideas, España, 2010/2011 invierno.

Samba Financial Group (2010): "The GCC increasingly diversified economies", Report Series, april 2010. Disponible en: <http://www.scribd.com/doc/29897481/GCCIncreasingly-Diversified-Economies-April-2010>

Sturm, Michael, Strasky, Jan, Petra, Adolf, Peskel, Dominik (2008): "The Gulf Cooperation Council countries, economic structures, recent developments and the role in the global economy", European Central Bank, Occasional Paper series $\mathrm{N}^{\circ}$ 92, p. 67. Disponible en: 〈http://www.ecb.europa.eu/pub/pdf/scpops/ecbocp92.pdf>

The Economist Intelligence Unit (2010): "The GCC in 2020: Resources for the future", Shutterstock. Disponible en: <http://graphics.eiu.com/upload/eb/GCC_in_2020_ Resources_WEB.pdf>

Artigo recebido dia 22 de junho de 2013. Aprovado em 20 de outubro de 2013. 


\title{
Conjuntura Austral
}

\section{RESUMO}

As monarquias do CCG estão entre os países com as maiores reservas de hidrocarbonetos do mundo. Em consequência, possuem matrizes econômicas e produtivas fortemente dependentes dos mesmos. O objetivo deste trabalho é analisar como se posicionam os Estados-membro do bloco frente à mudança climática.

\section{PALAVRAS-CHAVE}

Conselho do Cooperação do Golfo; Mudanças Climáticas; Hidrocarbonetos

\section{RESUMEN}

Las monarquías del CCG se encuentran entre los países con mayores reservas de hidrocarburos a nivel internacional. En consecuencia poseen matrices económicas y productivas fuertemente dependientes de los mismos. El objetivo del siguiente trabajo es analizar cómo se posicionan los Estados parte del bloque frente al cambio climático.

\section{PALAVRAS-CHAVE}

Consejo de Cooperación del Golfo; Cambio Climático; Hidrocarburos

\begin{abstract}
The GCC monarchies are among the countries with the largest hydrocarbon reserves worldwide. In consequence their economic and productive matrices are strongly dependent of them. The aim of this paper is to analyze how these states position themselves as regards climate change.
\end{abstract}

\section{KEYWORDS}

Gulf Cooperation Council; Climate Change; Hydrocarbons 


\title{
Conjuntura Austral
}

\section{UNIÃO AFRICANA (U.A): DESAFIOS E OPORTUNIDADES DA INTEGRAÇÃO}

\section{African Union (A.U): Challenges and Integration Opportunities}

\author{
Jacqueline A. H Haffner ${ }^{1}$ \\ Genivone Etmy Sequeira Viana ${ }^{2}$
}

\section{Introdução}

Não se pode ignorar que, a partir do fim da Guerra Fria, ocorreram profundas transformações no cenário mundial. Conjuntamente com estas transformações, ocorre também a busca por novas estratégias de inserção internacional e, em última instância, mudanças no padrão de atuação internacional dos Estados.

Neste novo cenário que se delineia, a proliferação de vários blocos econômicos nos dá uma dimensão do importante papel que a integração regional passa a ocupar,mediante a necessidade de construir com rapidez novas estratégias para sobreviver à guerra econômica.

Para o continente africano em particular, a integração regional apresenta-se como uma alternativa possível à sua posição marginal mediante o processo de globalização. Assim sendo, a criação da União Africana demonstra uma preocupação das elites locais na busca por novos caminhos,com vistas a superar os desafios do desenvolvimento do continente negro.

\footnotetext{
${ }^{1}$ Professora da Faculdade de Economia e Relações Internacionais (DERI) e do Programa de Pósgraduação em Estudos Estratégicos Internacionais (PPGEEI) da Universidade Federal do Rio Grande do Sul - UFRGS. E-mail: jacqueline_haffner@ hotmail.com

${ }^{2}$ Bacharel em Relações Internacionais pela Universidade Federal do Rio Grande do Sul - UFRGS. Email: geniviana@live.com.pt
} 


\section{Conjuntura Austral}

Ademais, a cooperação entre os países africanos apresenta-se como elemento chave, capaz de transformar situações e condições semelhantes, ainda que por vezes negativas, em oportunidades de cooperação e beneficio mútuo. Neste sentido, nossa análise sobre a União Africana é particularmente interessante e de suma importância se levarmos em consideração que sobre esta entidade recai a responsabilidade de adotar medidas e definir prioridades corretas para a execução de seus projetos nacionais em nível continental e global.

Entretanto, vale ressaltar que não obstante a importância assumida pela integração, não podemos concluir a priori que esta seja por si só capaz de resolver as variadas questões ligadas ao desenvolvimento, bem como a das demais vulnerabilidades sociais e institucionais - as quais se inserem em outro âmbito que não o da integração, como é o caso de grande parte dos países dessa região.

Vale salientar que, para conseguir o desenvolvimento, faz-se necessário um ambiente favorável, e que a estabilidade política do continente é fundamental para que se consigam avanços significativos no processo de integração.

\section{A União Africana}

A criação da União Africana no lugar da Organização da Unidade Africana é considerada uma ruptura importante nas relações externas dos países do continente, na medida em que a instituição da nova organização se traduz na esperança das elites locais de modificar as estruturas existentes.

A ideia da criação da UA inspira-se na ideologia do pan-africanismo. Segundo Visentini, sua fundação se insere no contexto da necessidade de uma organização capaz de fazer frente aos desafios potencializados pela situação gerada pelo encerramento do conflito bipolar (VISENTINI, 2010).

Nas palavras de Fernandes (2011), dada a entrada do novo milênio, ante o processo de globalização, e a posição adversa da África no comércio internacional, os objetivos da Organização da Unidade Africana se mostravam insuficientes para conduzir o desenvolvimento do continente. Tendo em vista este novo contexto, uma nova organização se fazia necessária. A União Africana vinha sendo preconizada desde 


\section{Conjuntura Austral}

a época de Kwame Nkrumah, ou seja, no pan-africanismo. Essas ideias teriam sido retomadas na $35^{\mathrm{a}}$ sessão de Conferência Ordinária dos Chefes de Estado e de Governo da OUA, realizada de 12 a 14 de julho de 1999, em Argel. Atentos na promoção de um maior fortalecimento da OUA, na globalização e no comprimento dos Objetivos do Desenvolvimento do Milênio, os lideres africanos se reuniram, entre 8 e 9 de setembro de 1999, em Sirte, na Líbia onde optaram pela substituição da OUA.

Esta conferência culminou com a "Declaração de Sirte", documento que estabeleceu a proclamação da União Africana, chamando para esta entidade a responsabilidade de gerir os assuntos do continente. Entretanto, a Ata Constitutiva foi adotada na Cúpula de Lomé, em 2000,entrando em vigor em 2001, em Lusaka. Mas seu lançamento oficial somente se daria em Durban (África do Sul), a 9 de julho de 2002.

Para Badir (2008), a criação da União Africana é de suma importância, pois, pela primeira vez, uma organização africanainspira confiança e gera grandes expectativas e esperanças no sentido de dar uma maior visibilidade no cenário social, político e econômico mundial propriamente como um bloco.

Já Muniz Ferreira acrescenta que esta criação surge num contexto diferente. Trata-se de uma nova fase, caracterizada pela eliminação dos últimos resquícios da colonização no continente, do regime racista da África do Sul em 1994, da pacificação de sociedades dilaceradas por guerras civis(a exemplo de Angola e Moçambique), dos avanços na democracia e da emergência de novas lideranças regionais, como os dirigentes sul-africanos.

Ante este novo contexto, a organização teria sido criada com o intuito de corrigir o legado negativo deixado pela antecessora OUA e recolocar a África no novo cenário que se vislumbrava. Com sede em Abis Abeba (Etiópia), compõem a UA todos os Estados africanos, à exceção do Marrocos. Com a admissão da República Árabe Saarauí Democrática (não reconhecida pela ONU), a organização totaliza 53 membros.

Do ponto de vista institucional, a estrutura da organização difere fundamentalmente da extinta OUA. A nova composição, como observada por analistas, parece assemelhar-se ao modelo de estrutura e formatação da atual União Europeia e surpreende pela sua complexidade e gigantismo. 


\section{Conjuntura Austral}

Com todo o aparato institucional implementado, cabe à União Africana desempenhar um papel de liderança no continente no que diz respeito, sobretudo, à harmonização e racionalização de políticas e programas de intercâmbio de experiências, de fortalecimento e capacidades institucionais. Assim sendo, a Comissão da UA foca especialmente, na paz e segurança, desenvolvimento social, questões ligadas à igualdade de gênero e água (FERNANDES, 2011).

Entretanto, em nível institucional, a União Africana encerra uma série de dúvidas quanto ao seu real significado. Neste aspecto, Ribeiro (2007) destaca que o processo de transição da OUA para UA coloca em discussão a viabilidade da instituição, se levarmos em consideração que esta não deixa claro quais suas diferenças e objetivos em comparação com sua antecessora.

Institucionalmente falando, o professor Dopcke (2002) levanta o fato da Comissão, do Parlamento Pan-Africano, do Conselho Econômico, Social e Cultural, do Tribunal de Justiça, bem como das instituições financeiras, instrumentos que representam o cerne institucional da União, permanecerem ainda com funções e poderes não claramente definidos.

Outro fato importante a se destacar é a falta de pagamento por parte dos Estadosmembros, o que afeta sobremaneira o bom funcionamento da organização. $O$ parlamento procura alternativas ao corte das contribuições ao seu orçamento por alguns Estados africanos em conflito, especialmente a Líbia, que era um dos maiores doadores da organização.

Segundo Francisca Domingos, "o conflito que culminou com a queda do presidente Muammar Kadhafi em 2011 resultou na cessação dos apoios ao órgão e provocou um déficit no orçamento". Não se pode afirmar ao certo o montante que o país disponibilizava para o orçamento do Parlamento Pan-Africano, mas a fama deste ser o maior contribuinte nos dá uma dimensão do problema pelo qual está passando. Sabe-se que, além da Líbia, seis outros países não mencionados não estão canalizando suas cotas para a União Africana, devido à instabilidade por que passam, situação que afeta as atividades do Parlamento e, em última instância, a própria União Africana. 


\section{Conjuntura Austral}

Considerando a atual conjuntura, a maioria das avaliações acerca da UA destaca o caráter não realista e até mesmo "megalomaníaco" da nova criação, apontando-se, assim, para a existência de uma enorme brecha entre o desenho e aquilo que de fato é considerado possível realizar. Destaca-se aí, passados quarenta anos da independência, a impossibilidade da mesma superar, num sentido profundo, a divisão do espaço político, social e econômico, criada pela inserção dependente do continente no sistema internacional.

$\mathrm{Na}$ opinião do professor Docpke, é evidente que o novo desenho da União Africana, as ideias de uma união econômica, de um parlamento africano ou de um exército africano não correspondem em absoluto à capacidade atual do continente, e, portanto, não têm chance de realizações concretas no curto prazo.

Munis Ferreira (2008) compreende esta intenção como um esforço ambicioso, levado a cabo por uma ampla coalizão de governos no intuito de fazer frente a uma gama de problemas enfrentados pelo continente. Mas entende que, mediante o fenômeno da globalização - um mundo cada vez mais assimétrico, excludente e inseguro, onde a promoção de grandes blocos econômicos tem sido uma realidade constante -, parece não haver alternativa para as nações africanas, a não ser investir fortemente em tal proposta, fortalecendo sua posição negociadora e estimulando intercâmbios econômicos.

Observa-se a presença de muitos obstáculos no mercado africano em particular, e no mercado financeiro em geral. Deveras, alguns aspectos podem ser salientados: condições macroeconômicas desfavoráveis (inflação alta e instável, déficit fiscal, dívida publica, etc.), volume restrito de demanda e fornecimento de produtos financeiros, fraco volume de transações, taxas elevadas impostas às operações financeiras, infraestrutura inadequada, limitada cultura financeira, governança econômica pobre etc. (UNIÃO AFRICANA, 2008).

Observando estes desafios, Ferreira (2008) acrescenta a acentuada subalternidade econômica dos países africanos no comércio mundial, salientando aqui a perda de relevância de suas importações e a subvalorização dos produtos exportados pelos países industrializados no comércio bilateral, aumentando ainda mais o abismo 


\section{Conjuntura Austral}

que separa as precárias economias do continente das indústrias high tech do mundo desenvolvido.

Ferreira aponta como desafio a questão da reestruturação produtiva, que demanda o uso crescente de tecnologia. Tal conjuntura exige grandes investimentos em pesquisa, elevando, desse modo, os custos da produção e uma necessidade cada vez maior de ampliação sistemática dos investimentos. Desta maneira, os países africanos, já excluídos do centro dinâmico da economia mundial em função do monopólio tecnológico dos países desenvolvidos, se veem também excluídos dos créditos e financiamento, e se veem com dívidas a pagar.

Estas adversidades têm sido dramáticas para o continente africano. De acordo com dados do Caderno do Terceiro Mundo, a participação do continente na economia global é atualmente, inferior a $2 \%$.O volume da sua interação a nível comercial com o resto do mundo declinou no decorrer da década de 1990-2000. A dívida externa, por sua vez, atinge 315 bilhões de dólares, superando o triplo de sua receita anual de exportações. A renda per capita africana caiu $20 \%$ desde 1980, particularmente na África subsaariana. O Investimento Direto Estrangeiro (IDE) no continente corresponde a menos de $5 \%$ do total obtido pelo terceiro mundo.

Ainda neste contexto, Palhares (2004) acrescenta que, além do fraco IDE recebido, os países pobres transferem mais recursos do que recebem dos países desenvolvidos e das organizações multilaterais, razões que o mesmo aponta como agravantes da piora das condições socioeconômicas da África, conjuntamente com o peso da dívida, que faz desviar importantes verbas dos setores da educação, saúde e serviços públicos. Para o autor, o problema não se resolve com o simples reescalonamento da dívida, mas sim com a anulação desta, já que especialmente na África Subsaariana o peso da divida tem se tornado um dos principais obstáculos ao desenvolvimento.

Alguns autores como Collier, Gunning e Chang, que objetivam uma analise profunda dos países africanos, buscando entender o fraco desempenho econômico apesar das reformas levados a cabo no quadro das Políticas de Ajuste Estrutural (os PAE), justificam o fechamento da economia internacional da África, apresentado razões 


\section{Conjuntura Austral}

tanto de ordem direta quanto de ordem indireta. Para estes autores, as diretas estariam ligadas ao excessivo controle sobre o comércio externo na forma de cotas e barreiras não tarifárias, altas tarifas aduaneiras e de imposto de exportação. Enquanto isso, as indiretasestariam associadas às políticas de câmbio desfavoráveis e restrições a atividades de exportação.

Seguindo esta linha de raciocínio, o Fundo das Nações Unidas para África (UNECA, 2006), conforme citado por Fernandes (2011), traz alguns elementos que também podemos considerar como inibidores da integração africana: a pobreza;as limitadas capacidades; um financiamento insuficiente; a adesão a múltiplos blocos regionais e a interrupção dos mandatos; economias pouco complementares; poucos centros de coordenação; antagonismo de liderança entre os países mais poderosos em vários setores; e a ausência de grupos de interesse nacional, tanto empresas quanto a sociedade civil, na integração regional.

Mshomba (2000) ainda considera que alguns dos desafios que se apresentam na questão da integração são de fato, a elevada dependência face aos países doadores, assim como, o domínio de países estrangeiros em temos de permissão de acesso a mercados, bem como, as constantes instabilidades políticas.

Não obstante os desafios, não é correto ignorar o esforço da União Africana na busca por melhores condições. Dados apontam para um melhor desempenho econômico no inicio do novo milênio praticamente em todos os países do continente. Embora fique claro que a pobreza não esteja erradicada, a percentagem da população que vive abaixo da linha da pobreza baixou de 47\% em 1999 para 41\% em 2004, devido à melhora no desenvolvimento econômico, estimada em cerca de 5\% em 2000(UNIÃO AFRICANA, 2008).

Ainda de acordo com a mesma fonte, mesmo que esse crescimento não se tenha dado de forma equitativa pelo continente e esteja longe daquilo que realmente se almejava (um crescimento em torno de 7 a $8 \%$ ) suscetível de sustentar um alívio no nível de pobreza na África, um número cada vez maior de países está entrando no caminho do crescimento. Consequentemente, em 2007, apenas $10 \%$ dos países do 


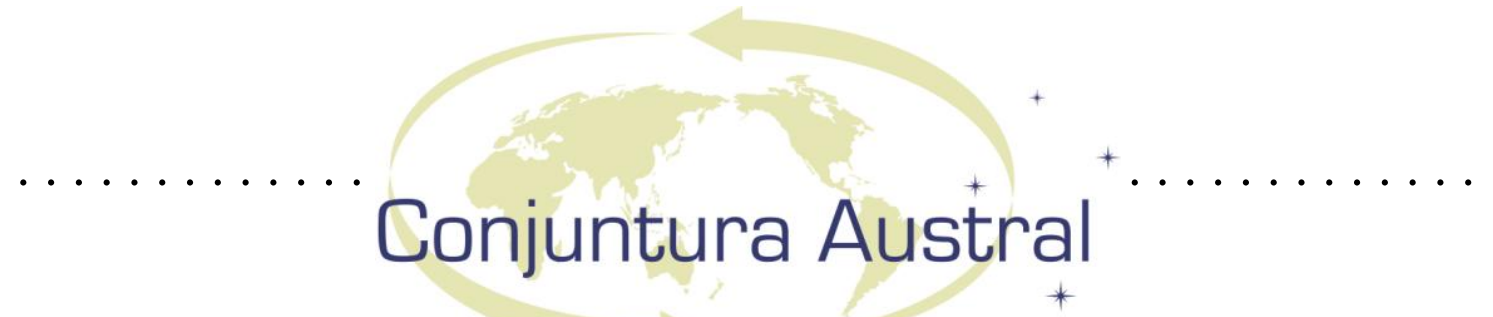

continente atingiram uma taxa de negativa de crescimento do PIB (UNIÃO AFRICANA 2008).

No que diz respeito à inflação, o continente conseguiu esforços significativos. A média da inflação baixou para 10\% no período de 2004-2007, sendo superior aos 5 a7\% obtidos na América Latina. O número de países com taxa de inflação inferior a $10 \%$ passou de 40\% durante o período 1998-2001 para 43\% durante o período de 2002-2005. Por sua vez, os reembolsos antecipados a países produtores de petróleo e a anulação da divida dos países pobres altamente endividados contribuíram significativamente para a redução da divida externa, baixando de $110,6 \%$ do PIB em 2005 para 7,7\% em 2007. A balança comercial melhorou globalmente na África, sob o impulso do superávit comercial dos países também produtores de petróleo (UNIÃO AFRICANA, 2008).

Ainda de acordo com esta fonte, o capital oriundo da África e o investimento no estrangeiro no setor imobiliário ou financeiro, se traduz em uma perda significativa em termos de poupanças e investimentos. Prejuízos apontam para entre $2,6 \%$ e $7 \%$ do PIB, nestes dois itens, montantes que variam entre 3 e 13 bilhões de dólares por ano de perda na África Subsaariana, fundamentalmente (Relatório Econômico da Comunidade Econômica Africana- CEA, 2006).

Quaisquer que tenham sido os dados, as dificuldades e melhorias até aqui apresentados, é indiscutível que o continente tenha o potencial necessário para promover um crescimento mais acelerado. Ribeiro (2007) observa que, para que isso venha a acontecer, é fundamental que se façam reformas políticas que garantam a paz e assegurem a estabilidade necessária aos investimentos.

Neste contexto, a União Africana surge como um instrumento fundamental e é sob esta ótica que deverá ser analisada: como um instrumento capaz de buscar e assegurar as condições necessárias à promoção da paz e do desenvolvimento africano.Obviamente, os objetivos da UA não são pequenos, bem como os desafios que ela terá de enfrentar. Para não cometer os mesmos erros que sua antecessora, a UA deverá, segundo Espada (2009), pautar-se por uma atuação mais firme e coerente.

Pela diversidade de identidades culturais presentes no continente, a atuação da União Africana pode ser considerada muito complexa, especialmente para a construção 


\section{Conjuntura Austral}

de uma entidade supranacional. Essa tarefa é difícil, porém não impossível. Portanto, a União Africana ainda tem um longo caminho a percorrer na busca por seu espaço no mundo globalizado.

\section{A Procura Por Novas Oportunidades}

As avaliações a respeito do desenvolvimento e do progresso da União Africana são passíveis de várias considerações. Neste sentido, verifica-se que muitos têm uma visão cética, até mesmo pessimista, quanto a um futuro melhor para o continente africano, sobretudo a curto e médio prazo, e consequentemente, para a União Africana, já que dela fazem parte quase a totalidade dos países do continente. Entendendo estas dificuldades, a seguir serão analisadas as reais oportunidades e as melhoras que a União Africana poderá proporcionar aos seus Estados-membros,em questões ligadas à paz e segurança, democracia, comércio e desenvolvimento, e de que forma estas variáveis afetam a integração econômica do continente.

\section{Paz e segurança}

Pode-se afirmar que a questão da segurança regional, mediante a ampliação de mecanismos, estratégias e políticas para assegurar e manter na paz no continente, se traduz numa das propostas e motivação da criação da União Africana.

O tema da paz e segurança tem sido uma preocupação constante da comunidade internacional. Oliveira (2007), afirma que a paz é uma das grandes preocupações deste século, constituindo, dessa forma, uma questão de interesse da opinião publica em geral, de políticos, de instituições nacionais e, em particular, internacionais.

Obviamente, a União Africana está atenta a este fato, já que parte da premissa de que a paz é um pré-requisito importante para os objetivos finais que qualquer país queira almejar. (UNIÃO AFRICANA, 2008). Especialmente, a partir dos anos 1990, onde se assiste nas palavras de Diallo (2011) um incremento dos conflitos associados ao fim da Guerra Fria.

Neste aspecto, Visentini (2007) coloca que, até o final da Guerra Fria, havia interesse político-estratégico envolvendo o continente, algo que de certa forma 


\section{Conjuntura Austral}

mantinha viva a importânciada região. No entanto, o fim da bipolaridade e do conflito Leste-Oeste, agravados pelo desaparecimento da URSS nofim de 1991, fizeram com que o continente perdesse sua importância estratégica e de barganha, e, em última análise, de sua própria importância econômica.

Se anteriormente a União Africana estava mais preocupada com os problemas ligados a questões econômicas ou de desenvolvimento, a partir de então, o grande desafio passou a ser o que era então securitário. A questão da segurança ampliou esse leque de prioridades e a ocupar o centro das atenções da entidade em análise. De igual modo, se antes da Guerra Fria a maioria dos conflitos eram entre os Estados, após a queda do Muro de Berlim os conflitos se tornaramintraestatais.Dentro desta perspectiva, Diallo (2011) salienta que, no que se refere à África, esses conflitos são conhecidos por serem étnicos ou tribais, e travados dentro dos Estados. Suas consequências são ainda maiores no plano sociopolítico, cultural e, sobretudo econômico, pois além de destruírem as poucas infraestruturas existentes, impedem, de igual modo, o desempenho de atividades econômicas nas áreas afetadas.

Não podemos desprezar a influência do legado deixado pela colonização europeia nessa dinâmica aqui apresentada. Embora os especialistas insistam sobre a heterogeneidade e a complexidade das causas desses conflitos, em suas abordagens raramente sobressai a reflexão política. Por certo, Porteous (2003) enfatiza que o fato de a política externa africana do ocidente privilegiar o desenvolvimento e a questão humanitária dos conflitos, a mesma tende a ocultar as dimensões políticas e, portanto, obscurecer o fato fundamental de que estes conflitos, na verdade, são somente uma parte do produto resultante do processo da evolução política indispensável à formação do Estado.

A par desta discussão a respeito das causas desses conflitos, é fundamental analisarmos o quanto eles podem e têm afetado o desenvolvimento do continente africano, e ver até que ponto a União africana tem sido ou não eficiente na resolução dos mesmos.

“Le Matin” (2010), conforme citado por Diallo (2011), destaca que o fogo da guerra atingiu 32 dos 53 países da África. Disto depreende-se que mais da metade dos 


\section{Conjuntura Austral}

países tiveram que se preocupar com investimentos em armamentos pesados e deixar de lado a problemática do desenvolvimento. Igualmente, Saraiva (2008) mostra que os conflitos consumiram entre 1990 e 2005 cerca de US\$ 300 bilhões, ou seja: este problema seria um dos mais importantes causadores da pobreza do continente africano.

Neste sentido, o Conselho de Paz e Segurança da União Africana é um órgão de suma importância e que outorga a esta entidade a possibilidade de intervenção políticomilitar, acabando desta maneira com a doutrina da não ingerência da organização continental que continha a sua antecessora, OUA. Desta forma, com a preocupação de se fazer mais presente, a União Africana adotou em 2003 um marco político para o Estabelecimento da Força Africana em Alerta e o Comitê Militar.

O Conselho de Paz e Segurança é um órgão decisivo para a prevenção, gestão e resolução de conflitos. Fazem parte dela 15 Estados-membros que detêm maior capacidade militar. Além de desempenhar as funções acima mencionadas, o Conselho de Paz e Segurança também é encarregado de preparar as ações de intervenções humanitárias da UA nos países em conflito, em campos de refugiados, etc.

Mearsheimer (2000) analisa a incapacidade da União Africana de por fim aos vários dos conflitos vivenciados pelo continente africano, que vive uma gravíssima crise humanitária. A exemplo de Darfur, o autor observa que a União Africana ainda não foi capaz de estabelecer mecanismos capazes ou eficientes que façam promover os direitos básicos e comportamentos estatais aceitáveis.

Para tornar-se efetiva, a União Africana deverá se pautar por uma atuação que tenha impacto na realidade vivenciada no continente. Dentro desta perspectiva, Ribeiro (2007) coloca como indispensável para o órgão a busca por uma estratégia eficaz de prevenção e solução de conflitos, numa instância superior dos mecanismos por ela criados, valendo-se do direito de intervenção para restaurar a paz e a segurança.

\section{A democracia}

Como no item anterior, a questão da democracia será analisada em relação ao continente africano como um todo.Consideramos que o Ato Constitutivo da União Africana consagra a vontade dos Chefes de Estado e de Governo da União de promover 


\section{Conjuntura Austral}

e proteger os Direitos do Homem e dos Povos, consolidar as instituições e a cultura Democrática, promover a boa governança e o Estado de Direito.Ao analisarmos assim a questão no âmbito do continente africano no geral, estaremos também nos referindo à União Africana que representa uma totalidade de 53 países.

A questão da democrática tem sido retomada com vigor, pois vem sendo alvo de atenções e estudos por vários segmentos da sociedade que têm se mobilizado em torno dessa ideia, na busca por direitos, por maior participação na vida pública e por justiça social.

O que se observa é que com o fim da Guerra Fria, na década de 1990, sucederam-se dois processos aparentemente contraditórios. A chamada terceira onda de "democratização" em mais de 30 países africanos coincidiu com a decadência e o colapso do poder centralizado de vários Estados pós-coloniais. Neste novo contexto político africano, a governança e direitos humanos começaram a ocupar um lugar central no discurso hegemônico que legitimou a causalidade entre a democracia e desenvolvimento e expansão da ideologia liberal, o que tem contribuído para diluir os limites da soberania do Estado pós-colonial. Observa-se, neste sentido, que a promoção de um bom governo, a governança democrática e os direitos humanos tornam-se uma estratégia central para completar a liberalização econômica que as instituições financeiras internacionais e os principais doadores sugerem aos países africanos.

Contudo, conforme bem coloca Branco (2006), ainda que tomemos como ponto de partida o final da Guerra Fria, não podemos descartar a influência das centenas de anos de domínio colonial europeu exercido sobre a quase totalidade dos países africanos, especialmente em relação à forma como este aspecto viria influenciar no desenvolvimento e, em última análise, no processo de democratização desses países.

De acordo com este autor, esta influência se faria sentir em dois aspectos. Primeiro, na formação da estrutura econômica; e,segundo, na formação do rompimento de laços culturais, ao aprisionar, por um lado, a diversidade étnica no seio de territórios arbitrariamente definidos, e, por outro lado, ao criar artificialmente as próprias diferenças étnicas. 


\section{Conjuntura Austral}

O autor ainda acrescenta que o fato da colonização em muitos países africanos ter-se dado em função de interesses em torno da exploração dos recursos naturais e das culturas exóticas constitui razão para sua excessiva especialização e progressiva dependência de voláteis mercados externos, cujos efeitos sobre o processo de democratização são bem conhecidos (BRANCO 2006).

Visentini coloca que "após uma breve redemocratização, muitos regimes autoritários estão voltando ao poder na África, ou, pelo menos, antigos ditadores vencem eleições ou reassumem na estreia de conflitos internos, geralmente com apoio popular”(VISENTINI, 2007). Desta forma, pode-se afirmar que a questão democrática na África ainda é muito frágil.

De fato, o continente africano é rico em maus modelos em matéria de democracia. Exemplos passados e presentes demonstram isso, como é o caso de Ruanda, onde a transição para a democracia culminou em genocídio; do Zimbábue; da Guiné Equatorial, onde o presidente se elegeu com quase 100\% dos votos; ou mesmo do Quênia, onde o processo eleitoral em 2008 quase levou a país à beira de uma guerra civil. Há também casos mais recentes, como a Líbia, o Egito e Guiné-Bissau.

É por isso que a Carta Africana sobre a Democracia, as Eleições e a Governança, no seu preâmbulo, reconhece as contribuições que a União Africana e as Comunidades Econômicas Regionais poderão prestar no que tange à promoção, proteção, reforço e consolidação da democracia e da boa governança. Estas instituições trabalham neste sentido, e estão cientes de que as mudanças anticonstitucionais de governo constituem uma das causas de insegurança, instabilidade, crise e até mesmo de violentos confrontos na África.

Observa-se que as democracias africanas ainda são mescladas com autoritarismo. Ainda não se pode definir seu sucesso ou seu fracasso.Contudo, a União Africana deve estar atenta ao entendimento de que a democracia somente terá a possibilidade de se desenvolver na sua plenitude quando os setores sociais e políticos estiverem ligados aos demais setores, e, em última analise, quando a representatividade estiver associada à limitação dos poderes e à consciência de cidadania. 


\section{Conjuntura Austral}

Certamente seria interessante que os Estados da União Africana passassem a levar em consideração que a democracia é o principal instrumento que os agentes de uma nação possuem para evitar a fome e desastres coletivos.

\section{Desenvolvimento e comércio}

Pode-se afirmar que na África as privações estão intimamente relacionadas com a ineficiência de mecanismos econômicos capazes de proporcionar trabalho digno a todos os indivíduos. A possibilidade de crescimento existe, mas não podemos ignorar quevelhos problemas ainda sobrevivem no continente, e se somam aos novos desafios. Portanto, a África ainda vivencia graves ameaças à sustentabilidade da vida econômica e social.

Sob este prisma, a União Africana deverá se mostrar capaz de fornecer suporte às diferentes instituições, a exemplo do mercado, governos, partidos políticos e o sistema educacional, ou, até mesmo, buscar favorecer a integração entre o mercado e o Estado, já que ambos mostram ser de fundamental importância em qualquer processo de desenvolvimento e de integração.

Ademais, partindo do pressuposto de que os países não desenvolvidos (como é o caso de vários pertencentes à União Africana) necessitam de políticas estratégicas de desenvolvimento para a superação dessa condição, a integração pode, de acordo com Dathein (2007), ser entendida como uma dessas estratégias, ou como uma forma de viabilizar essas políticas. No entanto, a adoção dessas medidas é difícil para um país isoladamente. Assim,a alternativa poderia ser a adoção de uma estratégia de desenvolvimento a nível regional.

Estimulando o crescimento dos países membros de blocos econômicos, em geral, e da União Africana, em particular, o processo de integração se consolidaria e mostraria potencial de desenvolvimento, o que, por sua vez, conduziria a um aumento de investimento interno e externo, respectivamente (DATHEIN, 2007).

Destarte, Palhares (2004) considera imprescindível o reforço do papel do Estado na África com a implementação do Estado Social, na qual é tem grande importância o desempenho e a participação consciente de atores sociais, ONGs e demais organizações 


\section{Conjuntura Austral}

da sociedade civil. Em suma, existiria a possibilidade de articular a política social com a macroeconômica, dado que ambas se reforçam respectivamente, e ainda investir nas produções do continente e na defesa dos interesses africanos nas instâncias internacionais, para assim promover o desenvolvimento e avançar com a União Africana.

Esta possibilidade de construir países economicamente viáveis a partir de uma entidade maior não é incompatível com a democracia, nem sua concretização depende de regimes autoritários. O crescimento requer um clima econômico propício. O desenvolvimento, como vimos e bem salienta Diallo (2011), é um conceito amplo, tal como o de segurança e ambos têm objetivos que não excludentes, mas sim mutuamente complementares: sem segurança não há desenvolvimento e o contrário também é verdadeiro, como mostra ser o caso de vários países africanos, especialmente da África Subsaariana.

Neste sentido, constata-se que a União Africana percebe a integração como a estrutura necessária para resolver os obstáculos do comércio entre os Estados africanos e assim criar maiores mercados regionais, que podem alcançar economias de escala e manter sistemas de produção e mercados ao mesmo tempo em que reforça a competitividade da África,promovendo, assim, o desenvolvimento (MONTE, 2010).

A abordagem regional tem sido considerada pela União Africana como a melhor ferramenta para o desenvolvimento do continente. Assim com o estabelecimento desta entidade e da Nova Parceria para o Desenvolvimento da África (NEPAD), as ações se centram na racionalização do aparelho estatal em busca do desenvolvimento econômico regional, através da identificação de projetos comuns compatíveis com as demandas e as afinidades dos diversos países.

Cabe ressaltar que, na busca pela unidade e por estratégias de desenvolvimento, algumas nações vem estabelecendo uma série de parcerias externas, que o continente temse esforçado em enfrentar coletivamente. Monte (2010)destaca entre essas parcerias externas a entrada de diversos países na Organização Mundial do Comércio (OMC), os acordos com o Caribe e o Pacífico e as ações com a União Europeia, bem como os laços 


\section{Conjuntura Austral}

comerciais já estabelecidos com grandes parceiros, como os Estados Unidos, Brasil, Índia e principalmente a China.

As estruturas vigentes internamente também devem ser analisadas: por um lado, a grande semelhança na estrutura de exportação dos países; por outro, as diferenças nos níveis de renda, industrialização e infraestrutura. Desse modo, a demanda por produtos de alto valor agregado exige importação de outros países fora do continente. Muitos países produzem os mesmos produtos, o que acarreta na preferência em comercializar com países terceiros, em vez do vizinho. Explicam-se, assim, fortes vínculos comerciais com nações externas, especialmente as ex-metrópoles, resultando na baixa percentagem de comércio dentro do próprio bloco.

Soma-se a isso tudo o fato de essas economias apresentarem características semelhantes aos exportadores primários, o que, por sua vez, faz com que estes países se tornem extremamente vulneráveis a crises externas. São economias carentes em indústrias e que, portanto, apresentam grande concentração de produtos primários na pauta de exportação.

Entretanto, se considerarmos que na década de 1970 o total de trocas comerciais entre os países africanos era de apenas 2\% de acordo com o Banco Mundial, os valores atuais conforme nos mostra a Tabela1 apresentam uma evolução crescente nas diferentes blocos:

Tabela 1- Comércio intrarregional na África- 2002/2008 (\% das exportações totais)

\begin{tabular}{|c|c|c|c|c|c|c|}
\hline Blocos/anos & 2002 & 2004 & 2005 & 2006 & 2007 & 2008 \\
\hline CEDEAO & $11,1 \%$ & $11,7 \%$ & $11,9 \%$ & $10,4 \%$ & $10,8 \%$ & $12 \%$ \\
\hline UEMAO & $12,6 \%$ & $12 \%$ & $12 \%$ & $12,2 \%$ & $12,4 \%$ & $14 \%$ \\
\hline CEEAC & $13 \%$ & n.d & n.d & $1,4 \%$ & n.d & n.d \\
\hline CEMAC & $13 \%$ & n.d & $2,0 \%$ & $4 \%$ & n.d & n.d \\
\hline SADC & $12,6 \%$ & $11 \%$ & $12 \%$ & $12,2 \%$ & n.d & $14 \%$ \\
\hline
\end{tabular}

Fonte: Fernandes (2011, p. 192)

A preocupação da União Africana tem sido no sentido de incrementar os baixos níveis de comércio intra-africanoe interno. O mapa atual, com muitas e pequenas 


\section{Conjuntura Austral}

economias, constitui um desafio ao desenvolvimento comercial do continente, conforme se pôde verificar na tabela apresentada acima.

Como bem observa Monte (2010), uma característica notável de integração regional na África pode ser percebida através da participação dos Estados africanos em vários acordos comerciais regionais. Atualmente, dos 53 países, 27 são membros de duas organizações regionais, 18 pertencem a três, um país participa de quatro entidades e só sete países mantiveram participação em apenas um bloco.

A análise da tabela nos permite perceber que a União Econômica e Monetária da África Ocidental (UEMAO) possui uma ligeira vantagem sobre o resto do grupo, com exceção da Comunidade de Desenvolvimento da África Austral (SADC), que se fortaleceu com a entrada da África do Sul.

De acordo com Perspectivas Econômicas na África (2012), na África Ocidental foram reforçados os laços entre a CEDEAO e a União Econômica e Monetária da África Ocidental (UEMOA). As duas instituições têm um programa comum de liberalização econômica e de convergência de políticas macroeconômicas. Na África Central, a CEEAC e a Comunidade Econômica e Monetária da África Central (CEMAC) estão reforçando os laços mútuos, com o objetivo de harmonizarem os seus programas. A CAO e a COMESA assinaram um memorando de entendimento para impulsionar a harmonização de políticas e programas. A COMESA e a SADC lançaram, igualmente, atividades conjuntas.

Estes aspectos demonstram um esforço conjunto dos lideres da União Africana em acelerar os esforços para remover os obstáculos que ainda criam barreiras à criação de uma área de comércio livre no continente. A Comissão da União Africana e outras organizações têm emitido recomendações para o crescimento do comércio intra-africano e para acelerar a área de livre comércio, objetivos apoiados pela União Africana.

De igual modo, a União Africana, juntamente com estas entidades regionais por ela reconhecidas, está trabalhando a fim de enfrentar os problemas através da eliminação de barreiras comerciais, do reforço da integração econômica, da promoção da livre circulação de pessoas. Além disso, a própria UA, os agrupamentos regionais e os governos nacionais estão tentando melhorar e reforçar os mercados financeiros. $\mathrm{Na}$ 


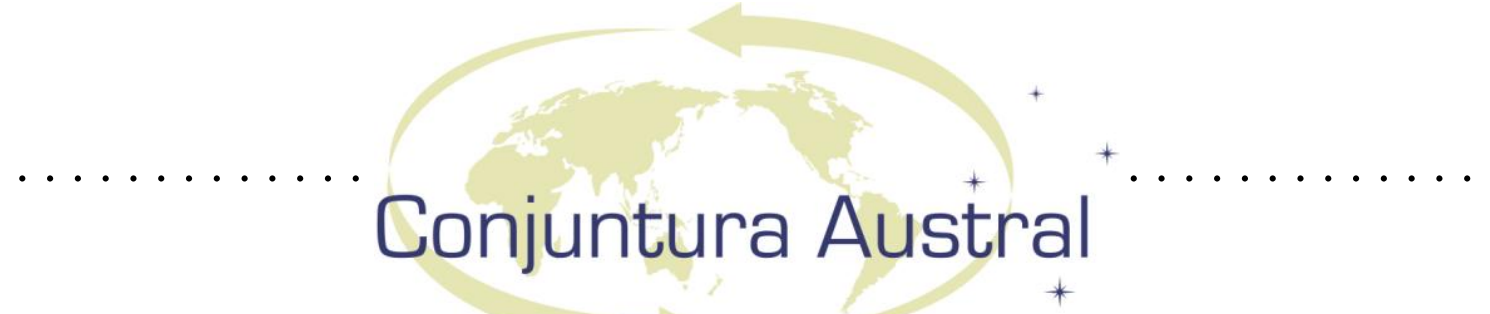

escala continental, a União Africana está trabalhando na criação do Banco Africano de Investimento (BAI), do Banco Central (BCA) e do Fundo Monetário Africano (FMA). Ainda de acordo com Perspectivas Econômicas na África (2012), a União Africana lançou o Programa Mínimo de Integração (PMI), onde são definidas áreas prioritárias em relação às quais as comunidades econômicas regionais podem reforçar a cooperação e beneficiar das vantagens comparativas da integração.

De acordo com Fernandes (2011), quando se fala da marginalização e em especial, no caso da África, no comércio internacional, geralmente tal referência diz respeito ao tratamento desigual que o continente recebe no comércio mundial. Neste aspecto, o autor salienta que os países africanos ocupam uma posição de extrema marginalização. Conforme o autor, não se trata, no entanto, de ignorar o beneficio que a participação no comércio global acarreta no desenvolvimento dos países.

Nesta ótica, não podemos ignorar o fato de que a África consome o que não produz e produz o que não consome. Assiste-se, desse modo, uma desregulamentação das trocas comerciais e além das restrições ao comércio, existem também grandes debilidades nas questões de cunho ambiental.

Não obstante as dificuldades acima mencionadas, segundo Mourão (1997) não há como negar a existência de potenciais a serem explorados com a expansão do comércio no continente. É o caso da possível triangulação envolvendo os espaços regionais do MERCOSUL, da SADC e da EU, centrada em torno de interesses que sejam reais e complementares dos três potenciais parceiros regionais.

Feitas as reformas políticas e econômicas e criadas as condições que garantam a paz e assegurem a estabilidade necessárias ao investimento, o World Bank prevê que o nível de crescimento para o continente poderá ser duplicado. De acordo com a mesma fonte, economias da África Subsaariana continuarão crescendo a uma média superior a $5 \%$ em 2011, com a expectativa de chegar a quase 6\% em 2012, devido às intervenções pontuais para estimular a produção em vários países.

Atualmente, a África constitui uma nova fronteira de oportunidades, além de abrigar algumas das economias que mais crescem no mundo. Nas palavras de Ribeiro: "ao voltar suas economias para fora, os países africanos têm como explorar e se 


\section{Conjuntura Austral}

beneficiarem do crescimento e da elevada demanda produzida pelas economias emergentes, particularmente pela China, pela Índia e mesmo pelo Brasil, que oferecem grandes oportunidades para o aumento de suas exportações” (RIBEIRO, 2007 P.10).

A partir desta perspectiva,é interessante analisarmos alguns dados, especialmente em relação ao engajamento da África com os BRICS. Segundo a ICTSD (2012), a taxa de crescimento do comércio dos BRICS com a África ultrapassou aquela do agrupamento com o restante do mundo, bem como a média de crescimento do comércio global. Particularmente no que se refere ao caso de Índia e China, o intercâmbio com a África responde por 2,6\% e 2,3\% de seu produto interno bruto (PIB), respectivamente. Quanto ao Brasil, esse percentual corresponde a 1,7\% e, no que diz respeito à Rússia, a 0,5\%. Nesses termos, a África do Sul é o integrante do agrupamento que apresenta o comércio mais intenso com o continente, tendo registrado, em 2010, fluxo comercial superior a 3\% de seu PIB (INTERNATIONAL CENTRE FOR TRADE AND SUSTENAIBLE DEVELOPMENT - ICTSD, 2012).

O intercâmbio do continente com a África do sul merece um destaque especial pelas características especiais desse país e pelo seu poderio frente aos vizinhos africanos. De acordo com ICTSD (2012), durante a crise financeira, no período 20082009, o comércio total entre a África do Sul e a África decresceu 24\%, passando de US\$ 21,2 bilhões em 2008 para aproximadamente US\$ 16 bilhões em finais de 2009. Contudo, no ano seguinte, verifica-se uma recuperação de $17 \%$ no comércio sulafricano com o continente, que atingiu US\$18,8 bilhões. Entretanto, cabe salientar que esse intercâmbio comercial está concentrado em poucos países: Nigéria (35\%), Angola (32\%) e Moçambique (8\%) compõem $75 \%$ das importações da África do Sul, enquanto Zimbábue (17\%), Moçambique (16\%) e Zâmbia (14\%) representam aproximadamente $47 \%$ das exportações.

Outro parceiro importante para o continente é a China, o maior externo à África. O comércio com os chineses passou de US\$ 3,5 bilhões em 1990 para mais de US\$ 120 bilhões em 2010, o que corresponde a cerca de dois terços do total comercializado pela África com os BRICS. 


\section{Conjuntura Austral}

A partir dos dados acima expostos, podemos constatar que, não obstante o crescimento no comércio da África do Sul com demais países do continente, verifica-se uma concentração deste em poucos países, assim como em produtos primários. O comércio de produtos de maior valor agregado permanece fraco, o que evidencia uma forte dependência do país de commodities e o comércio com os países de fora do continente está em franca ascensão. O papel ascendente das economias emergentes, como a China, a Índia e o Brasil, no comércio com África e no investimento, continuam ganhando força. Tal fato amplia as oportunidades para uma cooperação Sul-Sul mais profunda com vistas a promover a diversificação do mercado africano e do investimento.

Com relação à União Europeia, o comércio com a África está em seu auge, mas o desenvolvimento ainda está em curso. Segunda a imprensa portuguesa, a União Europeia é a maior parceira da África. As relações comerciais entre os dois blocos se intensificou nos últimos anos, de acordo com os mais recentes dados do Departamento de Estatísticas Europeu (Eurostat).

Conforme a Conferência das Nações Unidas para o Comércio e Desenvolvimento (UNCTAD, 2005), prevê-se um aumento dos fluxos de investimento para o continente, devido ao grande número de projetos anunciados na região, bem como a quantidade expressiva de investidores interessados nos recursos africanos e políticas que favorecem a entrada de IDE no continente. Desse modo, após décadas estagnadas, a economia africana passa a dar sinais de recuperação. Tem-se observado não apenas uma aceleração do crescimento econômico, como também novas oportunidades de comércio e investimento.

No entanto, é preciso tomar cuidado para que essas oportunidades sejam transformadas em benefícios. Neste sentido, segundo ICTSD (2012), os países africanos podem, por exemplo, adicionar aos projetos de infraestrutura termos e condições ligadas a áreas de maior necessidade e urgência. Do mesmo modo, faz-se necessária uma abordagem ativa, que permita o desenvolvimento de estratégias de cooperação que vão ao encontro dos objetivos de desenvolvimento regional e nacional. 


\section{Conjuntura Austral}

É preciso reconhecer, até o presente momento, o esforço louvável promovido pelos Estados africanos na promoção de reformas e nível econômico e político, na busca por uma inserção mais dinâmica no sistema internacional. A África deve nas palavras de Palhares, "se convencer que é possível realizar obras concretas com recursos e ideias inovadoras". Apesar dos desafios, é possível a construção de um futuro melhor (PALHARES 2004).

A União Africana deve continuar mostrando sua capacidade latente para prosperar. A diversidade cultural, a riqueza dos recursos naturais, a extensão e variedade do território de 30 milhões de $\mathrm{km}^{2}$, o potencial humano de cerca de um bilhão de habitantes (dos quais 60\% com menos de 25 anos), a boa governança como uma exigência e um mercado com oportunidades enormes de expansão são trunfos dessa caminhada. A União Africana aposta nessa direção: seu objetivo principal visa, precisamente, à promoção do desenvolvimento e da integração do continente.

Sendo assim, pode-se dizer que a União Africana acredita que os países do continente possam se transformar, majoritariamente, em países de rendimento médio nos próximos anos, investindo estrategicamente nos seus recursos naturais, face à demanda concorrencial mundial dos mesmos, acelerando a industrialização, integrando o comércio mundial com mais valia e desenvolvendo os fatores de competitividade em todos os domínios.

É certo que a África tem pela frente numerosos desafios, mas estes, se geridos estrategicamente, poderão ser transformados em oportunidades. A União Africana pode, neste contexto, ter um papel de mais relevância na elaboração de uma agenda continental que seja simultaneamente coerente com o processo de desenvolvimento africano e inclusiva de todos os interesses das nações africanas.

\section{Conclusão}

O presente artigo teve como objetivo analisar o processo de integração da União Africana, com a tentativa de identificar os principais desafios e as possíveis oportunidades desta entidade. 


\section{Conjuntura Austral}

A partir desta análise, pudemos constatar que a criação da União africana em substituição à antiga Organização de Unidade Africana, se dá não somente com o intuito de corrigir o legado negativo deixado pela antecessora, mas também se traduz numa vontade política dos dirigentes africanos na busca por uma maior e melhor inserção do continente africano no panorama mundial.

Ao analisarmos a União Africana como condição primordial para a avaliação dos êxitos e das dificuldades resultantes do processo de integração dos países do continente no contexto global, entendeu-se que a organização em consideração desempenha um papel importante na adoção e definição de medidas e prioridades concretas para a inserção de projetos nacionais a nível continental.

Verificamos em grande medida que se torna fundamental a criação de um ambiente econômico mais favorável nos países que compõem a União Africana, sobretudo na África Subsaariana, onde os resultados econômicos são mais ínfimos, em virtude dos conflitos que assolam parte desta região, criando um ambiente econômico desfavorável ao investimento.

Não obstante as dificuldades, alguns dados analisados apontam para uma melhora no desempenho econômico no inicio do novo milênio. Ainda que este crescimento não tenha se dado de forma equitativa e esteja aquém daquilo que realmente se esperava, um número cada vez mais significativo de países tem entrado para o curso do crescimento. Neste aspecto, a África Subsaariana merece especial atenção por parte da União Africana, que não deverá medir esforços para por fim aos conflitos e criar as condições adequadas para o investimento, criando condições que garantam a paz, a segurança e a estabilidade necessárias ao investimento.

Portanto, cabe à União Africana atuar de forma mais firme e coerente nos aspectos políticos, econômicos e sociais do continente, buscando sempre fortalecê-los. Neste sentido, vimos que a África tem a possibilidade de promover um crescimento maior, motivado pelo processo de globalização, e adquirir vantagens da maior demanda de países emergentes como a China, Índia e Brasil.

Fica claro que, devido a diversidades culturais existentes na África, a atuação da União Africana pode ser considerada muito complexa, inclusive para a construção de 


\section{Conjuntura Austral}

uma identidade supranacional. Contudo, para não cometer os mesmos erros que sua antecessora e realmente alcançar os objetivos para qual foi criada, deverá pautar sua atuação de uma forma firme e coerente nos aspectos negativos que afligem o continente.

Em suma, considera-se que a União Africana tem um longo caminho a percorrer no que se refere à construção de uma entidade como organização e, em seguida, na busca por um maior desenvolvimento econômico, político e social. Entretanto, é preciso acreditar que o continente tem potencial para isso e levar adiante medidas que façam prevalecer suas prioridades.

\section{REFERÊNCIAS}

BRANCO, Carlos Manuel Martins (2006), Etnicidade e Violência Étnica: As Diferentes Abordagens Teóricas e a sua Utilidade na Gestão de Conflitos, Revista Militar.Disponível em: <www.revistamilitar.pt/modules/articles/article>. php?id=158. Acesso em: 5 de outubro de 2012.

BADIR, Mbuyi k. África en La globalización neoliberal: las alternativas africanas. Revista THEOMAI. Estudios sobre sociedad y desarrollo, Buenos Aires, n. 17. semestre, 2008.

BANCO MUNDIAL. Integração regional em África. Notas de antecedentes para reunião de consultas sobre integração regional, 2007. Disponível em: $<$ http://siteresources.worldbank.org/EXTAFRREGINICOO/Fresources/RID_2007_port. pdf $>$. Acesso em 23 de novembro de 2012.

CHANG, Há-Joon.Kicking Away the Ladder: development strategy in historical Perspective. London: Anthem Press, 2002.

COMUNIDADE ECONOMICA AFRICANA (CEA), Relatório Económico sobre a África, 2006.

DATHEIN, Ricardo. Integração Econômica e políticas de Desenvolvimento: experiência e perspectivas para América Latina.UFRGS, 2007. 


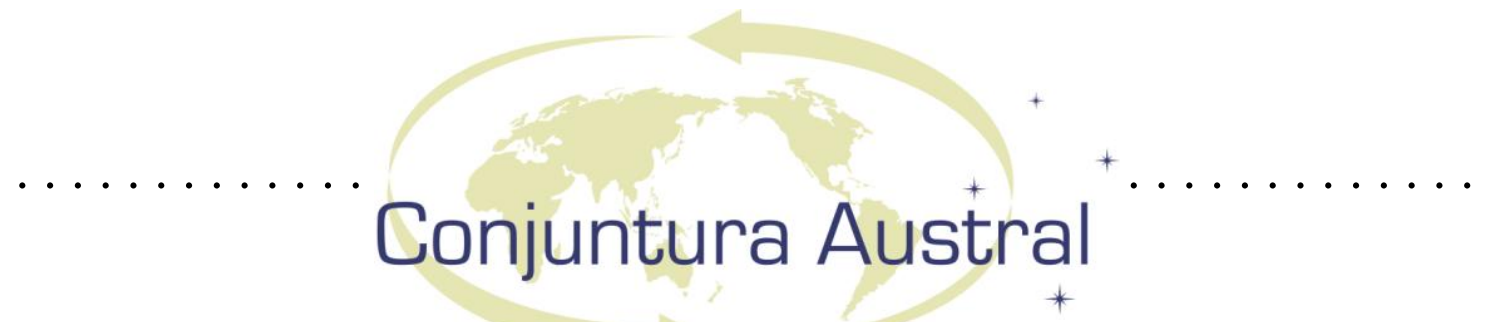

DIALlO, Mamadou A. Paz e desenvolvimento na África do século XXI: um balanço do período pós-guerra Fria. Videre, Dourados, MS, ano 3, n. 5, p. 43-61, janjun.2011.

DOPCKE, Wolfgang. Sai a Organização da Unidade Africana- entra a União Africana: novas encenações do continentalismo africano. RERIDIANO 47 N.28/29, 2002.

ESPADA, Valéria M. G. União Africana: um estudo sobre a mediação de conflitos, 2009.

EUROSTAT. Africa-EU: Economic indicators, trade and investment. European Union, 2012 .

FERREIRA, Muniz. A África contemporânea: dilemas e possibilidades, 2008. $12 \mathrm{f}$.

FERNANDES, Lito Nunes. Economia Política de Integração da África Ocidental: A União Econômica e Monetária do Oeste Africano (UEMOA) como Estratégia para o Desenvolvimento Regional. Tese (Ciências Econômicas). Programa de doutorado em Economia do Desenvolvimento. Universidade Federal do Rio grande do Sul. Porto Alegre, 2011.

INTERNATIONAL CENTRE OF TRADE SUSTAINABLE DEVELOPMENT (ICTSD). Um engajamento da África com os BRICS, 2012. Disponível em <www.ctsd.org/i/news/pontes/145829/>. Acesso em: 15 de out. 2012.

LUNARDON, Jonas. Conflitos contemporâneos na África Negra e suas causas ambientais. Porto Alegre, 2010.

LE MATIN. Disponível em: <http://www.lematindelafrique.com/index.php? option=com_content \&view=article $\& i d=3690 \% 3$ Aneocolonialisme-lafrique-en-a-marredetre-tutelle\&Itemid=97> . Acesso em: 18 de outubro 2012.

MEARSHEIMER, John. "The False Promise of International Institutions" In: BROWN, Michael; et al. Theories for ward Pace. Cambridge (Mass.), MIT Press, 2000.

MONTE, J. Bosco. Integração Regional da África: a saída para o desenvolvimento. Mundorana, 2010.

MOURÃO, Fernando Augusto Albuquerque. "A política externa brasileira e sulafricana para a África Austral.” In GUIMARÃES, Samuel Pinheiro. (Org.). Brasil e África do Sul: riscos e oportunidades no tumulto da globalização. Brasília: CNPq/IPRI, 1997. 


\section{Conjuntura Austral}

MSHOMBA,Richard.E. Africa in the Global Economy, 2000, Lynne Rienner Publishers. (A Choice Magazine Outstanding Academic Book).

NÓBREGA, Álvaro. A democracia em África. JANUS, 2010.

OLIVEIRA, Gilson Batista de. Uma discussão sobre o conceito de desenvolvimento. Revista FAE, Curitiba, v. 5, n.2, p. 37-48, maio/ agosto 2007.

RIBEIRO, Claudio Oliveira. União Africana: possibilidades e desafios, 2007.

PALHARES, Paulo. S. Comércio e desenvolvimento em África, 2004.

PORTEOUS, Tom. Afrique: conflits et développement, 2003. p. 307-350. In:

Politique étrangére; no 2.

VISENTINI, Paulo Fagundes. A África moderna. Um continente em mudança (16602010). Porto alegre: Leitura XXI, 2010.

Paulo Fagundes; Ribeiro Luiz Dario; PERREIRA, Ana Lucia Danilevicz. Breve história da África. Porto Alegre: Leitura XXI, 2007.

SARAIVA, José Flávio Sombra. A África na ordem internacional do século XXI: mudanças epidérmicas ou ensaios de autonomia decisória? São Paulo: Atual, 2008.

UNECA.Rationalizing Regional EconomicCommunities: ARIA II.Economics Commission for Africa, AdisAbeba, 2006.Disponível em:

<htpp://www.uneca.org/aria2/front matter, pdf >. Acesso em: 18 de setembro de 2012.

UNIÃO AFRICANA. Relatório de estudo de viabilidade sobre a criação da bolsa panafricana de valores, 2008. Disponível em: <http://au.int/en/>. Acesso em: $18 \mathrm{de}$ setembro de 2012.

Artigo recebido dia 25 de março de 2013. Aprovado em 25 de outubro de 2013. 


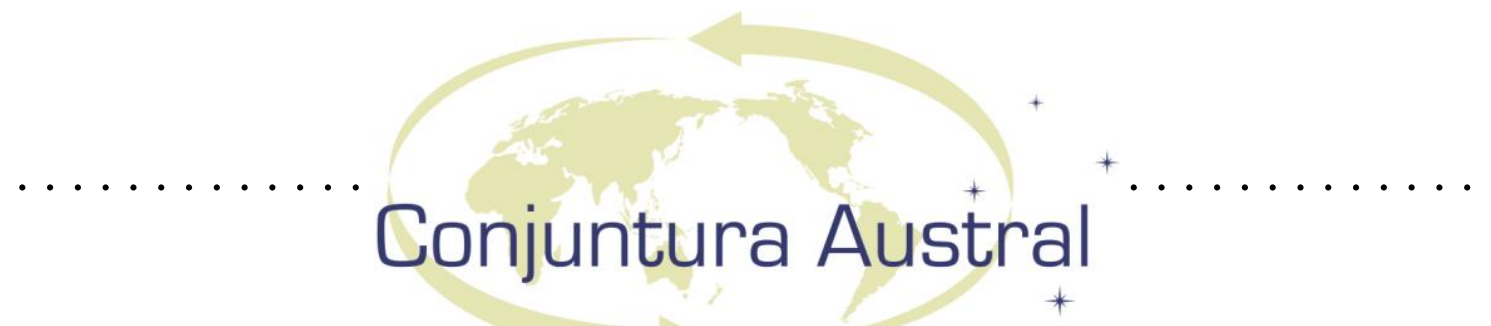

\title{
RESUMO
}

Este artigo procura analisar os desafios e as oportunidades da União Africana (UA). Para tanto, tenta-se demonstrar que a sua criação se insere dentro de uma estratégia maior em busca do desenvolvimento. Neste sentido, a organização teria sido criada com o intuito não só de inserir a África no panorama econômico mundial, preenchendo o legado negativo deixado pela antiga antecessora, a Organização da Unidade Africana (OUA), mas também para resolver os problemas sociais, políticos e econômicos enfrentados pelo continente negro, os quais foram agravados pelo fenômeno da globalização. Levando em consideração esses fatos, o objetivo do trabalho é, portanto, à luz dos desafios e das oportunidades vivenciadas pelo continente, analisar em que medida a União Africana tem sido capazde fazer frente aos problemas de seus Estados-membros.

\section{PALAVRAS-CHAVE}

União Africana; Integração; Desafios; Oportunidades.

\begin{abstract}
This paper aims to analyze the challenges and opportunities of the African Union, showing that its creation falls within a larger search strategy for development. In this regard, the African Union would have been created with not only the intention of setting Africa in the world's economic scenery - filling the negative legacy by its predecessor, the Organization of African Unity - but as well with the intention of solving social, political and economic issues faced by the black continent, issues which have grown due to globalization phenomenon. Considering these facts, the purpose of this paper is therefore to examine, under the light of challenges and opportunities faced by the African continent, how the African Union has been able to fight the social, political and economic problems of its Member States since its foundation.
\end{abstract}

\section{KEYWORDS}

African Union; Integration; Challenges; Opportunities; 


\title{
Conjuntura Austral
}

\section{A IMIGRAÇÃO HAITIANA PARA O BRASIL: CAUSAS E DESAFIOS}

\section{Haitian Imigration to Brazil: Causes and Challenges.}

\author{
Isaias Albertin de Moraes ${ }^{1}$ \\ Carlos Alberto Alencar de Andrade ${ }^{2}$ \\ Beatriz Rodrigues Bessa Mattos ${ }^{3}$
}

\section{Introdução}

O presente artigo - tendo como unidade de análise os atuais fluxos migratórios para o Brasil e alicerçando nos conceitos de refugiados e visto humanitário - empenharse-á em investigar o caso da hodierna imigração haitiana para o país.

A predileção do caso em questão justifica-se em razão de suas singularidades, como a relação entre a participação brasileira na Missão das Nações Unidas para a estabilização no Haiti - MINUSTAH e o processo migratório de haitianos para o país, de sua contemporaneidade e de sua magnitude. A imigração haitiana para o Brasil, segundo o Itamaraty, pode ser comparada historicamente com a de italianos e de japoneses, que desembarcaram no país entre o período imperial e os primeiros anos da República. ${ }^{4}$

\footnotetext{
${ }^{1}$ Especialista em Relações Internacionais pela Universidade de Brasília - UnB (2008) e, atualmente, é mestrando em Ciência Política e Relações Internacionais pelo Instituto Universitário de Pesquisas do Rio de Janeiro - IUPERJ. Pesquisador do Grupo de Análise de Prevenção de Conflitos Internacionais GAPCon. E-mail: isaiasalm@gmail.com

${ }^{2}$ Delegado da Polícia Civil do Amazonas. Professor de Direitos Humanos no Programa de Especialização em Segurança Pública - FAMETRO e de Direito Penal - Uninorte/Laureate. Mestrando em Sociologia pelo IUPERJ. E-mail: carlos.aaa@ hotmail.com

${ }^{3}$ Pesquisadora do GAPCon. Mestranda em Ciência Política e Relações Internacionais pelo IUPERJ. Especialista em Comércio Exterior pela Universidade Federal do Rio de Janeiro - UFRJ. E-mail: beatrizrbm@gmail.com

${ }^{4}$ Ver: Vinda de haitianos é maior onda imigratória ao país em cem anos, publicado em Folha de S. Paulo, [http://www1.folha.uol.com.br/mundo/1033447-vinda-de-haitianos-e-maior-onda-imigratoria-ao-pais-emcem-anos.shtml]. Disponibilidade: 12/01/2012.
} 


\section{Conjuntura Austral}

Entre as diversas teorias sobre migrações ${ }^{5}$, o estudo optou pelo tipo HistóricoEstruturalista. Os autores dessa corrente, em especial Gino Germani, Charles Wood, Michael Piore e Paul Singer, ao apreciarem os processos migratórios analisam diversos elementos dentro de um dado sistema. Para a Teoria Histórico-Estruturalista, os fatores determinantes da imigração são interdependentes, logo não sendo aconselhável metodologicamente serem avaliados de forma isolada.

Segundo Germani (1974), para um estudo eficiente do processo migratório, é preciso levar em conta não somente os fatores repulsivos e atrativos que motivaram o deslocamento de pessoas de sua terra mãe. A pesquisa precisa avaliar, também, as demais condições sociais, culturais e subjetivas presentes tanto no país de origem quanto no de destino, ou seja, em todo o sistema.

$\mathrm{O}$ artigo buscou, portanto, analisar, ao longo do texto, a recente imigração haitiana para o Brasil em três níveis. O primeiro é o ambiental, caracterizado pelos fatores de expulsão e de atração, pela natureza e pelas relações comunicacionais e de acessibilidade entre as áreas do sistema. O segundo nível é o normativo, formado pelos padrões comportamentais, institucionalização social, papéis e demais elementos que oferecem suporte referencial para os indivíduos calcular objetivamente sua existência. Por fim, o terceiro nível é o psicossocial que aprecia as ações e as expectativas concretas dos indivíduos. (GERMANI, 1974).

Ressalta-se, ademais, que, para os estudiosos da Teoria Histórico-Estruturalista, os processos migratórios são sempre condicionados historicamente. (SINGER, 1973). O recente fluxo de imigrantes provenientes do Haiti para o Brasil, dessa maneira, precisa ser compreendido a partir dos processos de mudanças conjunturais sofridos pelos dois atores.

O estudo procurou abordar, portanto, em um primeiro momento, os aspectos históricos-estruturais que possibilitam compreender o atual cenário políticosocioeconômico do Haiti. Importante destacar, nesta fase, a criação da MINUSTAH,

\footnotetext{
5 Para conhecimento das demais teorias sobre migrações ver: GONÇALVES, Ortelinda. Migrações $e$ Desenvolvimento. Porto: Fronteira do Caos, 2009.
} 


\section{Conjuntura Austral}

com a liderança brasileira, e sua relação com o recente fluxo migratório de haitianos para o Brasil.

Em sua segunda parte, o artigo buscou apresentar dados recentes da imigração haitiana para o país. Para obter uma análise situacional mais fidedigna dos acontecimentos vivenciados, o texto primou pela triangulação das informações. Essas foram colhidas, desse modo, por meio de uma abordagem sistemática de organização e de avaliação crítica de fontes primárias e secundárias, tais como: revistas, jornais, fotografias, resoluções, portarias, memorandos, discursos, entre outros. As interpretações dos dados foram feitas de forma qualitativa

Verifica-se que o artigo, como quase todas as pesquisas exploratórias, foi desenvolvido com a finalidade de proporcionar uma visão geral sobre uma determinada realidade. A metodologia adotada nas duas primeiras partes consistiu na pesquisa bibliográfica, histórica e na observação in loco do fenômeno, mormente, no estado do Acre e do Amazonas.

Por fim, o estudo procurou avaliar os principais aspectos da problemática, equacionando possíveis soluções para que o governo brasileiro proporcione oportunidades a milhares de haitianos oriundos de um país politicamente e economicamente instável e que procuram, no Brasil, um recomeço.

\section{Contextualização histórica}

A recente crise generalizada que se instalou na primeira república negra do mundo não pode ser entendida de forma pontual e simplória. É necessário compreender sua história, marcada por intervenções, regimes ditatoriais, corrupção e desastres ambientais, originando a atual realidade socioeconômica e política do Haiti.

O passado do país mais pobre da América $^{6}$ é marcado pela violência, desigualdade social e instabilidade política desde o início de sua formação. A princípio, a ex-colônia francesa enfrentou treze anos de lutas sangrentas para conseguir sua independência em 1804, tornando-se a primeira república negra do mundo.

\footnotetext{
${ }^{6}$ Segundo relatório de 2010 da United Nations Conference on Trade and Development - Unctad, o Haiti é o país mais pobre da América e está entre os 49 mais pobres do mundo.
} 


\section{Conjuntura Austral}

Posteriormente, entre 1915 a 1934, tropas dos Estados Unidos da América - EUA ocuparam o país com a alegação de garantir os interesses estadunidenses durante a Primeira Guerra Mundial.

No contexto da Guerra Fria, os estadunidenses continuaram influenciando a política haitiana ao apoiarem a ditadura do médico François Duvalier, conhecido como Papa Doc. Após a morte de François, seu filho, Jean-Claude Duvalier, o Baby Doc, assumiu o poder. O período ditatorial da família Duvalier foi marcado pelo totalitarismo e pelo terror policial dos tontons macoutes (bichos-papões) - a guarda pessoal do governo. Essa exterminou a oposição, explorou a crença da população no vodu e perseguiu a Igreja Católica.

Apesar dessa forte repressão, em 1986, Baby Doc teve de deixar o Haiti em razão dos constantes protestos populares contra seu regime. Em 1990, depois de mais um longo período de instabilidade e violência, foram realizadas eleições presidenciais diretas. Jean-Bertrand Aristide, ex-padre salesiano e partidário da Teologia da Libertação, foi eleito como mandatário do país.

Em 1991, contudo, ocorreu um golpe de estado e Aristide foi retirado do Haiti, retornando ao poder somente em 1994 com apoio de uma coalizão militar liderada pelos os EUA, com aval da Organização das Nações Unidas - ONU e da Organização dos Estados Americanos - OEA. Em 2000, Aristide se elegeu presidente novamente, mas houve suspeitas de fraudes eleitorais, estabelecendo uma crise entre governo e oposição.

Em 2000, na segunda vitória de Jean-Bertrand Aristide para presidente, compareceram às urnas menos de $10 \%$ dos eleitores, pois os principais partidos de oposição boicotaram o pleito em protesto contra supostas fraudes nas disputas eleitorais legislativas de maio do mesmo ano. Concomitantemente ao elevado índice de abstenções, houve grande violência na capital, onde três bombas explodiram deixando 2 mortos e 17 feridos. Em decorrência dos problemas identificados nas eleições legislativas e perante as novas suspeitas de fraudes, a oposição negou-se a aceitar o resultado. Aristide fora acusado de ter usado o governo de seu aliado René Garcia Préval para agir de forma ilegal e antidemocrática. 


\section{Conjuntura Austral}

As forças oposicionista, compostas por muitos dos tontons macoutes e militares da reserva se insurgiram, primeiramente, na cidade de Gonaives. A revolta, em pouco tempo, espalhou-se por todo o país e membros da oposição começaram a ocupar importantes regiões, a tomada de Porto Príncipe era questão de tempo.

A França e os EUA, inditosos com a imigração generalizada de haitianos fugidos da guerra civil $^{7}$, alegavam que somente a renúncia de Aristide poderia conter a onda de violência, a crise na ilha e o iminente derrame de sangue na capital. Em 2004, dessa forma, em uma ação rápida, Aristide foi retirado à força do país por militares estadunidenses com apoio dos franceses e, segundo o ex-padre, ele teria sido obrigado a renunciar. $^{8}$

Após a suposta abdução de Aristide, o presidente do Supremo Tribunal haitiano, Bonifácio Alexandre, assumiu o comando do país em 29 de fevereiro de 2004 e solicitou ajuda à ONU para contenção da crise. O Conselho de Segurança das Nações Unidas - CSNU, atendendo ao pedido do mandatário interino, estabeleceu a Força Multinacional Interina - MIF e, em abril de 2004, o Conselho aprovou a Resolução 1.542 dando origem à MINUSTAH comandada pelo Brasil.

Em janeiro de 2010, dificultando ainda mais a frágil situação sociopolítica haitiana, o país, que se recuperava de três furacões, que o atingiu em 2009, sofreu as consequências de um terremoto de magnitude sísmica de 7.3 na escala Richter. Porto Príncipe foi duramente atingida e estima-se que $80 \%$ das construções foram seriamente danificadas, incluindo escolas, hospitais, postos policiais e o próprio palácio presidencial. Além dos danos materiais, acredita-se que, aproximadamente $230 \mathrm{mil}$ haitianos perderam suas vidas e 1,5 milhões ficaram desabrigados em razão do tremor. (GIRALDI, 2012).

\footnotetext{
${ }^{7}$ A diáspora haitiana foi um dos maiores movimentos migratórios já recebidos pelos EUA nos anos recentes. Em 2008, foram registrados aproximadamente 535 mil haitianos nascidos no país descendentes dos milhares de refugiados. Ver: SARMIENTO, Luís C. O Brasil e a MINUSTAH: As motivações e as consequências de uma operação liderada pelo Brasil. Fortaleza: Monografia, p.74, 2010.

${ }^{8}$ Fato negado pela diplomacia dos EUA. Ver: EUA dizem que é 'absurda' acusação de golpe no Haiti, publicado em BBC Brasil, [http://www.bbc.co.uk/portuguesenoticias/story/2004/03/040302aristidebg.shtml]. Disponibilidade: 02/03/2004.
} 


\section{Conjuntura Austral}

Atualmente, o Haiti encontra-se com o sistema político desorganizado, a economia destroçada e a população desnutrida, padecendo com a rápida disseminação do vírus da Síndrome da Imunodeficiência Adquirida - AIDS e da bactéria Vibrio cholerae, a Cólera. Esse quadro de completa desesperança faz com que muitos haitianos optem por deixar o país com destino, principalmente para o Canadá, os EUA, a França, as Antilhas Francesas, a República Dominicana e o Brasil.

\section{Destino Brasil}

O recente fluxo migratório de haitianos para o Brasil iniciou-se de forma tímida, após o tremor de 2010, porém intensificou-se no final de 2011 e começo de 2012. Estima-se que, neste período, cerca de 4.000 imigrantes haitianos, segundo dados do Ministério da Justiça - MJ, entraram ilegalmente no país. Os haitianos adentraram principalmente pelas fronteiras do Acre e do Amazonas, mas há rotas nos estados de Roraima, Mato Grosso e Amapá.

Segundo estimativa do Ministério das Relações Exteriores - MRE o montante de haitianos em território brasileiro já supera a marca de 10.000, sendo que, até 30 de junho de 2013, 6.052 estavam com seus vistos permanentes regularizados, segundo o Memorando $n^{\circ}$ 907/2013 da Secretaria Nacional da Justiça do MJ.

Evidencia-se que a leva de imigrantes provenientes do Haiti para o Brasil é fenômeno dinâmico, com variação de tempo e de espaço bem marcantes, pois, conforme dados do Conselho Nacional de Imigração - CNIg, órgão colegiado vinculado ao Ministério do Trabalho e Emprego - MTE, no ano de 2010, foram concedidas autorização de permanência somente para 4 haitianos. Em 2011, foram 709, no entanto, em 2012 , foram 4.682 e, até junho de 2013 , foram 870 concessões. $^{9}$

\footnotetext{
${ }^{9}$ Fonte: Base Estatística Geral CNIg - Detalhamento das autorizações concedidas em 2012, publicado em Ministério do Trabalho e Emprego - MTE [http://portal.mte.gov.br/geral/estatisticas.htm]. Disponibilidade: 30/06/2013.
} 


\section{Conjuntura Austral}

Tabela 1 - Autorizações para concessão de visto permanente ou residência permanente no Brasil.

\begin{tabular}{|c|c|c|c|c|c|}
\hline Pais & 2010 & 2011 & 2012 & $1^{\circ}$ Sem. 2012 & 2013 \\
\hline HAITI & 4 & 709 & 4682 & 2137 & 870 \\
\hline PAQUISTÃO & 0 & 0 & 0 & 0 & 17 \\
\hline SENEGAL & 0 & 0 & 0 & 0 & 6 \\
\hline NOVA GUINÉ & 1 & 0 & 1 & 1 & 3 \\
\hline CONGO & 0 & 1 & 2 & 0 & 1 \\
\hline SOMÁLIA, REPÚBLICA & 0 & 0 & 0 & 0 & 1 \\
\hline OUTROS & 0 & 1 & 2 & 2 & 5 \\
\hline NÃO INFORMADO & 0 & 0 & 19 & 14 & 2 \\
\hline Total & 4 & 711 & 4706 & 2154 & 953 \\
\hline
\end{tabular}

Fonte: Ministério do Trabalho e Emprego - MTE. Base Estatística - CNIg - 30/06/2013

O Brasil se torna cada dia mais atrativo para os haitianos, pois a liderança na MINUSTAH, a presença de diversas Organizações Não Governamentais - ONGs brasileiras atuando de modo expressivo na ilha, tais como a Viva Rio, a ActionAid, a 99 Creixell, a Pastoral da Criança, a Diaconia, o Grupo de Apoio à Prevenção da Aids GAPA, entre outras, os símbolos, a cultura, as referências e o crescimento econômico do Brasil fizeram com que o país seja visto simpaticamente pela população do Haiti.

O Brasil, como forma de impulsionar o desenvolvimento do Haiti, mantém diversos projetos em seu território, com destaque para o auxílio na construção da usina hidrelétrica no Rio Artibonite, no sul do país. Além disso, a Empresa Brasileira de Pesquisa Agropecuária - Embrapa promove o programa Embrapa Hortaliças. Esse incentiva a produção de hortaliças na região de Kenscoff com financiamento da Agência Brasileira de Cooperação - ABC. A Embrapa ainda mantém na região uma unidade de validação de tecnologia, contando com unidades demonstrativas de milho, arroz, feijão e mandioca. Para potencializar o gerenciamento dos recursos hídricos, a Embrapa também fez o mapeamento do país por satélite.

O Brasil, na Conferência Internacional para o Desenvolvimento Econômico e Social do Haiti, realizada em 2007, em Madri, assinou acordo com o governo da Espanha para recuperar a cobertura vegetal da Bacia do Mapou, um dos principais rios haitianos. 


\section{Conjuntura Austral}

O esporte também vem sendo usado como instrumento para a redução da violência no Haiti. O Ministério do Esporte brasileiro, em parceria com o Fundo das Nações Unidas para a Infância - Unicef, promove os programas: Segundo Tempo e Pintando a Cidadania. Esses, além de possibilitar a prática de esportes durante as atividades escolares, foram responsáveis pela instalação de uma fábrica de bolas, onde 200 detentos que cumprem penas alternativas exercem trabalho remunerado.

Outra frente de atuação está no combate à violência contra a mulher. A Secretaria Especial de Políticas Públicas para Mulheres e o Ministério da Saúde do Brasil contribuem para a elaboração de um programa nacional haitiano de prevenção à violência de gênero no país. O projeto conta com o auxílio do Fundo das Nações Unidas para a População e prevê a criação de um sistema de atendimento às vítimas.

Com apoio do Banco Mundial, o Brasil atua em mais dois projetos. Um é concernente à gestão do lixo em Porto Príncipe. O programa visa à melhoria dos serviços de coleta de resíduos, o fornecimento de equipamentos e de consultores, além da capacitação de profissionais. $\mathrm{O}$ outro projeto tem como objetivo o incremento do sistema de fornecimento de merenda escolar e de restaurantes universitários em todo território nacional.

O governo brasileiro também é responsável pelo desenvolvimento de um centro de formação profissional em parceria com o Serviço Nacional de Aprendizagem Industrial - Senai em Porto Príncipe. A unidade, que inicialmente deverá primar pela qualificação de mão de obra para construção civil, terá capacidade para profissionalizar mil pessoas por ano.

Em relação à saúde, o Brasil, além de manter os hospitais de campanha do exército e construir cisternas para fornecer água potável à população, estabeleceu, em 2004, em parceria com o Canadá, o Programa Nacional de Imunização do Haiti. O trabalho realiza diversas campanhas de vacinação no país.

Depreende-se que a atuação brasileira no Haiti, por meio desses projetos apresentados, pelas ONGs e em virtude da liderança da MINUSTAH desde 2004, transformou o país em um referencial no imaginário dos cidadãos haitianos. Isso vem levando muitos migrantes do Haiti a escolherem o Brasil como destino. O movimento 


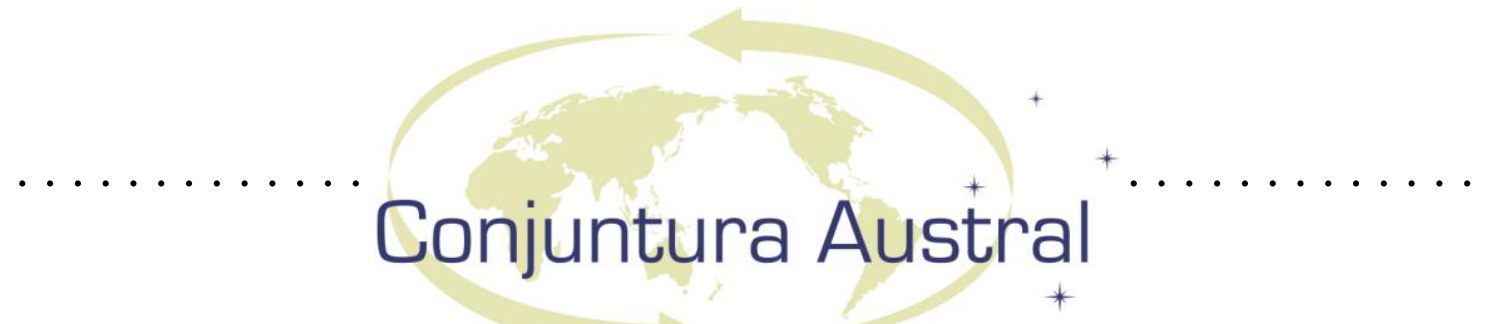

migratório, portanto, além de ser ocasionado da repulsão decorrente da crise políticasocioeconômica e das recentes catástrofes naturais, é influenciado pelos fatores de atração verificados no Brasil.

O atual crescimento econômico brasileiro - muitos haitianos relataram em entrevistas que ouviram sobre a construção da usina de Belo Monte, que iria contratar 25 mil trabalhadores de uma só vez - a sedução cultural e esportiva - o jogo da seleção brasileira de futebol, em Porto Príncipe, no ano de 2004, despertou ainda mais o interesse dos haitianos no Brasil. Além disso, o acolhimento dos primeiros imigrantes haitianos em território brasileiro, que foi realizado de forma amigável, diferentemente do que ocorreu em outros destinos onde a migração haitiana foi duramente repreendida, criou a imagem de um país acolhedor, servindo de motivação para a escolha do Brasil como possível novo lar.

Para chegar ao Brasil, os haitianos partem, geralmente, de Porto Príncipe seguindo por via terrestre para a República Dominicana. De lá vão por via aérea para o Panamá e para o Equador, seguindo viagem de ônibus até Peru ou Bolívia. Após adentrarem nos países vizinhos ao Brasil, seguem viagem de barco ou caminhando pela floresta, até as cidades de Tabatinga no Amazonas ou Brasiléia e Epitaciolândia no Acre. (LOUIDOR, 2011). Esse percurso até as cidades acreanas foi realizado, segundo a Secretaria de Justiça e Direitos Humanos do Estado do Acre, por cerca de 500 haitianos somente no período entre Natal e Ano Novo de 2011.

A princípio, os haitianos solicitaram refúgio com base no Direito Internacional dos Refugiados e na legislação do Brasil. O Conselho Nacional de Refugiados Conare, no entanto, entendeu que o motivo apresentado pelos estrangeiros deslocamento por desastre natural, econômicos e sociais - não se enquadravam nas

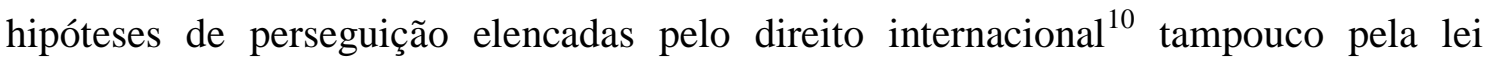
brasileira vigente. ${ }^{11}$

\footnotetext{
${ }^{10}$ Segundo o Estatuto dos Refugiados de 1951 e o Protocolo de 1967 da Agência das Nações Unidas para Refugiados - ACNUR, promulgado no Brasil em 1961, enquadra-se uma pessoa como refugiada quando "[...] receando com razão ser perseguida em virtude da sua raça, religião, nacionalidade, filiação em certo grupo social ou das suas opiniões políticas se encontre fora do país de que tem a nacionalidade e
} 


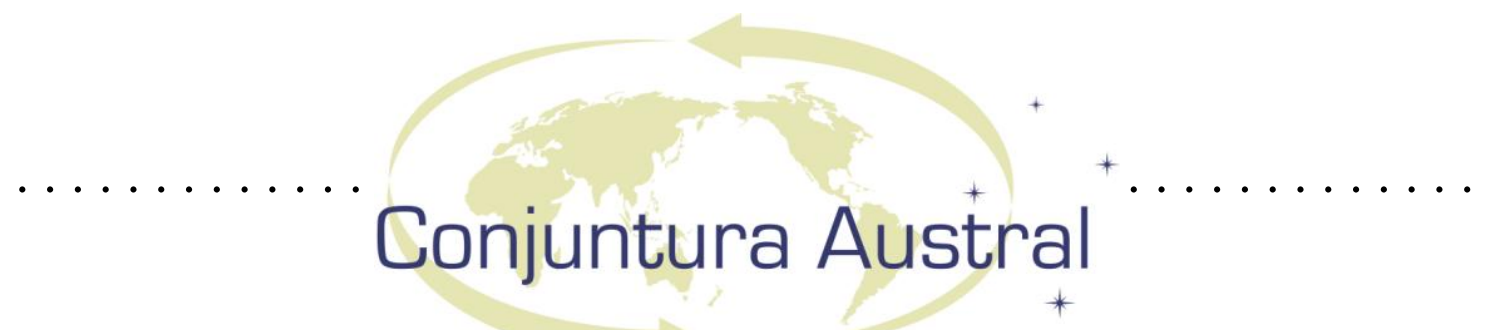

Dessa maneira, o Conare remeteu o caso ao CNIg, com vistas a obter uma solução legal para a questão. Assim, em uma decisão histórica, o CNIg concedeu visto humanitário de residência ${ }^{12}$ aos haitianos, permitindo que eles possam trabalhar e estudar no Brasil. Além dessas medidas, o Conare outorgou um protocolo que lhes permite obter o Cadastro de Pessoa Física - CPF e a Carteira de Trabalho e Previdência Social - CTPS. ${ }^{13}$

O governo brasileiro tem se empenhado para intensificar a liberação de vistos e de documentos aos haitianos que já se encontram em solo brasileiro, bem como vem treinando novos agentes da Polícia Federal, contudo o tempo para obtenção dos papéis é de três meses em média. O Estado do Acre, por meio da Secretaria de Justiça e Direitos Humanos, busca prestar auxílio aos haitianos, todavia, as condições dos imigrantes, principalmente na cidade de Brasiléia, são consideradas precárias.

O Ministério Público Federal no Acre - MPF/AC, desse modo, ingressou com uma ação civil pública para que a União garanta os direitos humanos a esses imigrantes. Segundo a ação, assinada pelo procurador da república Anselmo Henrique Cordeiro Lopes, a falta do reconhecimento de refúgio aos haitianos consistiria violação de seus direitos e os colocariam em acentuada situação de vulnerabilidade, expondo-os a crimes típicos de exploração humana, como: prostituição, trabalho escravo, tráfico de pessoas, extorsões, entre outros. O procurador, também, afirmou que o Brasil tem atentado duplamente contra os direitos humanos desses indivíduos: ao deixar de prestar-

não possa ou, em virtude daquele receio, não queira pedir a proteção daquele país." Ver: Artigo 1, Convenção de Genebra de 1951, relativa ao Estatuto de Refugiado.

${ }^{11}$ De acordo com a Lei 9.474 de 22 de julho de 1997, o Brasil considera refugiado o indivíduo que "I. devido a fundados temores de perseguição por motivos de raça, religião, nacionalidade, grupo social ou opiniões políticas encontre-se fora de seu país de nacionalidade e não possa ou não queira acolher-se à proteção de tal país; II. não tendo nacionalidade e estando fora do país onde antes teve sua residência habitual, não possa ou não queira regressar a ele, em função das circunstâncias descritas no inciso anterior; III devido a grave e generalizada violação de direitos humanos, é obrigado a deixar seu país de nacionalidade para buscar refúgio em outro país.

${ }^{12}$ Este visto é novo e especial para o Haiti, não havendo casos similares para imigrantes provenientes de outras nações. Depois que receber o documento, o haitiano tem um prazo de até cinco anos para comprovar sua situação de emprego e residência no Brasil junto às autoridades imigratórias brasileiras.

${ }^{13}$ Segundo a Superintendência Regional do Trabalho e Emprego no Amazonas já foram emitidas 1.391 CTPSs para os refugiados do país caribenho. Ver: MELO, Daisy. Número de haitianos supera expectativa em mutirão trabalhista em Manaus, publicado em: D24AM [http://www.d24am.com/noticias/economia/numero-de-haitianos-supera-expectativa-em-mutirao-trabal hista-em-manaus/48717] Disponibilidade: 22/01/2012. 


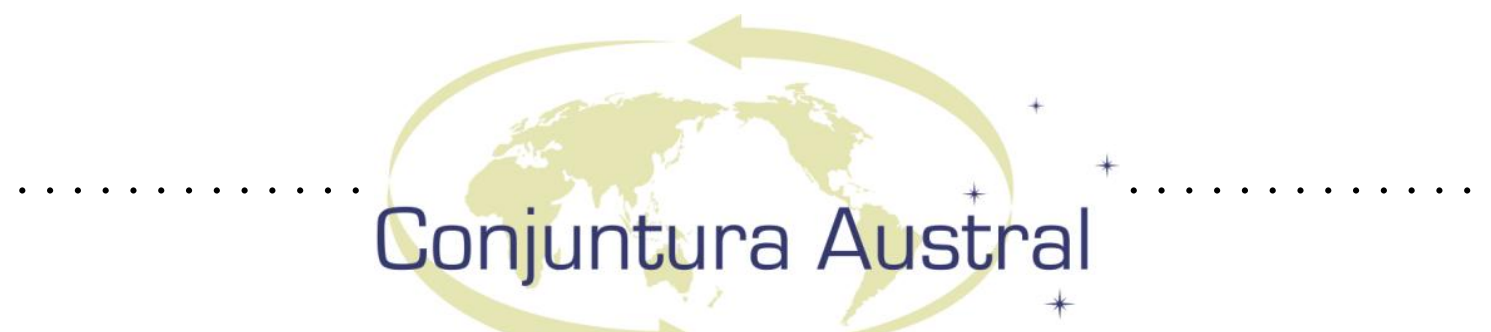

lhes assistência humanitária adequada e ao dificultar-lhes o ingresso em território brasileiro. $^{14}$

Em janeiro de 2012, com vistas a ordenar a diáspora haitiana para o país, o governo brasileiro publicou a resolução $n^{\circ} 97$ do CNIg. Essa estabeleceu uma série de medidas, entre as quais se destacam: a de regularizar os imigrantes do Haiti que já se encontram em território brasileiro e a de conceder, por meio da Embaixada em Porto Príncipe, 1.200 vistos anuais, um limite de 100 vistos por mês para haitianos dispostos a trabalharem no Brasil. ${ }^{15}$

No primeiro mês em que vigorou a resolução do CNIg, a Embaixada brasileira em Porto Príncipe concedeu apenas $30 \%$ da cota. A procura, segundo o embaixador do Brasil no Haiti, Igor Kipman, foi significativa, todavia, a maioria dos interessados era barrada nos critérios de elegibilidade. O haitiano postulante a obtenção do visto brasileiro deveria possuir passaporte em dia, comprovante de residência, atestado de bons antecedentes e ainda desembolsar US\$200,00. Mesmo que se adequasse em todos os critérios, o candidato deveria ainda esperar, de acordo com Kipman, cerca de um mês para emissão dos documentos. (FELLET, 2012)

Essas exigências praticamente inviabilizam grande parte da população haitiana de enquadrar-se no processo de imigração para o Brasil. O Haiti encontra-se, atualmente, destroçado, com índices de desemprego na ordem de $80 \%$ e com mais de $70 \%$ da população tendo acesso a apenas uma refeição por dia. (RIBEIRO, 2007). Nos

\footnotetext{
${ }^{14}$ Segundo a ação civil pública do MPF/AC, o instituto do refúgio não está isolado no Direito Internacional e deve ser compreendido como instrumento de garantia do exercício pleno dos direitos humanos. Além disso, a ação argumenta que o direito ao refúgio não pode ficar estaticamente ligado ao fundamento da perseguição política, mas deve ser dinamicamente entendido, em decorrência das novas ameaças aos direitos humanos, tais como: ambientais, sociais e econômicas. Evidencia-se, ademais, que obrigação do Brasil de atender e de acolher os haitianos, segundo a ação, tem fundamento no próprio texto constitucional. Esse expressamente sujeita o Brasil à "prevalência dos direitos humanos" (art. 4 , II, CRFB), bem como o obriga a guiar-se pela solidariedade humana em relação aos povos da América Latina, de acordo com o art. $4^{\circ}$, parágrafo único. Por fim, importante ressaltar que a Lei 9474/97, estabeleceu que refugiado é todo aquele que "devido a grave e generalizada violação dos direitos humanos, é obrigado a deixar seu país de nacionalidade e buscar refúgio em outro país". Fonte: Ministério Público Federal - Procuradoria da República no Acre.

${ }^{15}$ Ver: Resolução Normativa n$^{\circ} 97$ do MTE publicada no dia 13 de janeiro de 2012, na página 59 do Diário Oficial da União.
} 


\section{Conjuntura Austral}

últimos 15 anos, além da MINUSTAH, o país recebeu quatro missões da $\mathrm{ONU}^{16}$ sem ter sua realidade modificada concretamente, gerando desesperança e falta de perspectivas na população.

Além disso, o Brasil pressionou diplomaticamente o Peru e o Equador a exigirem vistos para a entrada de haitianos em seus territórios. (CHADE, 2012). Enquanto o Presidente peruano Ollanta Humala estabeleceu a exigência de vistos para haitianos em maio de 2012, o Presidente equatoriano, Rafael Correa, manteve a tradição do Equador de cidadania global, pois o país não exige visto para nenhum estrangeiro.

Tais medidas, consideradas pelo governo federal como essenciais para propiciar segurança jurídica e pessoal aos imigrantes, receberam severas críticas das organizações voltadas à proteção dos direitos humanos. Para essas, a resolução fez com que o Brasil fechasse suas fronteiras, dificultando a entrada de pessoas provenientes do Haiti, incentivando a ação de grupos de coiotes, além de não atenderem os haitianos que residem em outros países, como Republica Dominica, ou os que estavam em percurso rumo ao território brasileiro, principalmente nas zonas comuns com o Peru, Equador e a Bolívia.

Salienta-se que os haitianos que procuram o Brasil para reconstruírem suas vidas, em sua maioria, possuem algum grau de qualificação profissional, portanto não são refugiados iletrados e sem preparo. Muitos deles possuem curso técnico, curso superior e falam até três idiomas, entre eles o espanhol e o francês. O mercado de trabalho brasileiro, entretanto, os exploram, principalmente aqueles que aqui estão em condição ilegal, como mão de obra barata e, não raramente, com poucos direitos trabalhistas empregados.

Percorrido mais um ano desde a publicação da Resolução Normativa n 97/2012 do CNIg, a imigração ilegal haitiana para o Brasil não cessou. Em abril de 2013, o governador do Acre, Tião Viana, decretou estado de emergência social. A ONG Conectas Direitos Humanos, que vem acompanhando a situação dos haitianos em

\footnotetext{
${ }^{16}$ Foram: United Nations Mission in Haiti - UNMIH (1993-1996); United Nations Support Mission in Haiti - UNSMIH (1996-1997); United Nations Transition Mission in Haiti - UNTMIH (1997) e United Nations Civilian Police Mission in Haiti - MIPONUH (1997-2000).
} 


\section{Conjuntura Austral}

Brasileia, realizou, em agosto deste ano, um levantamento no estado. De acordo com a Conectas, há mais de 800 imigrantes haitianos vivendo em condições precárias, em galpões com capacidade máxima para 200 pessoas, sem qualquer tipo de saneamento básico e sem condições descentes de higiene. A junção de superlotação, com precariedade das instalações, com baixa nutrição e com o esgoto a céu aberto faz com que vários haitianos se adoeçam, e, assim, sobrecarregando o já deficiente sistema de saúde de Brasileia. ${ }^{17}$

Após a decretação de estado de emergência social, o governo federal liberou $\mathrm{R} \$$ 784 mil para ajudar o governo do Acre nas ações emergenciais de atendimento aos imigrantes haitianos, principalmente em Brasileia e Epitaciolândia. (CHAGAS, 2013). Verifica-se, entretanto, que o montante de recursos financeiros destinados para as medidas humanitárias executadas pelos órgãos públicos para a problemática haitiana é limitado.

Dessa forma, as instituições da sociedade civil vêm desempenhando importante papel na delicada situação dos haitianos em zonas de fronteiras. Como exemplo, podese citar a atuação da Igreja Católica, que tem buscado cooperar na regularização dos imigrantes, além de fornecer-lhes abrigo e alimentação. O fluxo migratório contínuo, entretanto, tem superado a capacidade de ajuda ostentada pelas paróquias, gerando superlotação nos albergues e impossibilidade do atendimento a todos.

O Estado do Amazonas, onde a imigração é em menor escala e onde o governo possui mais recursos, está auxiliado os haitianos com doações de colchões, de beliches e de cestas básicas. Houve, ademais, o encaminhamento às vagas de emprego, a oferta de cursos da língua portuguesa, inglesa e espanhola e a qualificação profissional nas áreas de informática, hotelaria, restaurantes, construção civil e indústria.

Por fim, depois de diversas criticas e com resultados aquém do esperado, o CNIg revogou, em abril de $2013^{18}$, a Resolução Normativa $n^{\circ}$ 97/2012. No momento, não há

\footnotetext{
${ }^{17}$ Ver: Relatório Violações de Direitos Humanos em abrigo destinado a acolher haitianos na cidade de Brasiléia, norte do Brasil, publicado em Conectas Direitos Humanos [ http://www.conectas.org/ ]. Disponibilidade: 19/08/2013.

${ }^{18}$ Resolução Normativa $n^{\circ} 102$ do MTE publicada no dia 29 de abril de 2013, na página 96 do Diário Oficial da União.
} 


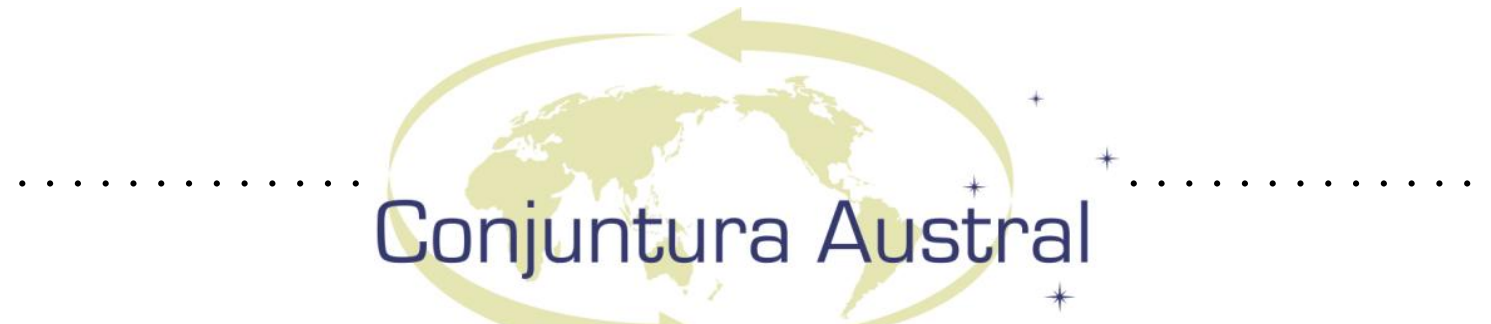

mais limites para emissão de vistos brasileiros para haitianos. A nova Resolução Normativa $n^{\circ} 102 / 2013$ estabeleceu, ademais, que os vistos não serão emitidos exclusivamente pela Embaixada do Brasil em Porto Príncipe, mas haverá novos postos em outros países que serão credenciados pelo Itamaraty. ${ }^{19}$ Com essas ações o governo federal espera evitar que os haitianos sejam vitimas dos grupos de coiotes.

\section{Considerações Finais}

O crescimento econômico do Brasil, as grandes obras de infraestrutura - como as da Copa do Mundo de 2014 e as dos Jogos Olímpicos do Rio de Janeiro de 2016 bem como a perspectiva da exploração de petróleo da camada do Pré-Sal, tendem a transformar o país em um novo destino para migrantes do mundo. A recente vinda de haitianos para o Brasil expôs a fragilidade das instituições nacionais para lidar com situações que envolvem imigração ilegal.

O Brasil não possui recursos humanos e técnicos para a formação de equipes de intervenção rápida em zonas de fronteiras, há pouca cooperação entre as forças policiais estaduais, federais e o exército e não há o desenvolvimento de um sistema integrado e eficiente de gestão de áreas limítrofes com as nações vizinhas.

Segundo Relatório de Auditória Operacional do Tribunal de Contas da União TCU de $2012^{20}$, a Polícia Federal possui 26 unidades em estados de fronteiras, com um efetivo de 898 agentes (14\% do total), 155 delegados (8,7\% do total), 296 escrivães (15,4\% do total), 69 peritos (6,3\% do total) e 21 papiloscopistas (4,6\% do total), perfazendo 1.439 policiais (12,4\% do total). Esse contingente é responsável para uma faixa de fronteira de $16.886 \mathrm{~km}$ de extensão, na qual o Brasil faz divisa com 10 países sul-americanos.

O TCU apontou, além disso, carências básicas como a falta de coletes balísticos para todos os agentes, a ausência de carros, entre outros recursos essenciais para as

\footnotetext{
${ }^{19}$ Até 30 de junho de 2013, o Brasil já havia cedido 4 vistos permanentes para haitianos na Embaixada de Quito no Equador e 8 pela Embaixada de Santo Domingo na República Dominicana. Fonte: Memorando n 907/2013 da Secretaria Nacional da Justiça do MJ.

${ }^{20}$ Ver: Relatório de Auditória Operacional. Sistema Nacional de Políticas sobre Drogas - Parte 1. Tribunal de Contas da União, publicado em [http://portal2.tcu.gov.br/TCU] . Disponibilidade: $17 / 05 / 2013$.
} 


\section{Conjuntura Austral}

ações policias. O estudo, ainda, realizou um levantamento entres os agentes e os delegados que atuam nas regiões 66,3\% apontaram "ruim" ou "péssima" a suficiência de recursos humanos na fronteira. Para 32\%, as instalações das delegacias são "ruins" ou "péssimas".

Deve-se observar, ademais, que a Polícia Federal não tem capacidade de atender satisfatoriamente os imigrantes que chegam e os que estão no Brasil, pois está empenhada com outras tarefas, como a repressão ao tráfico de drogas e de animais silvestres, ao contrabando e aos crimes de "colarinho branco".

Denota-se que diante desse quadro, o ideal seria o estabelecimento de uma agência de imigração federal, tal como fez, por exemplo, o governo argentino na década de 1970 com a criação da Dirección Nacional de Migraciones de la República Argentina. A instalação de um órgão exclusivo para imigração pelo governo federal permitiria a especialização dos profissionais na legislação especifica ao tema e no conhecimento de idiomas. A fundação da agência possibilitaria, ademais, a liberação de efetivo policial para o reforço de patrulhamento nas zonas limítrofes do país, principalmente na região norte.

Alie-se, a essas carências, o fato de que o Estatuto do Estrangeiro, instituído em 1980, durante o Regime Militar (1974-1985) e sob a ótica da Lei de Segurança Nacional, está defasado e adota políticas restritivas como meio de combater a criminalidade ligada à imigração. $\mathrm{O}$ momento histórico da elaboração do Estatuto do Estrangeiro fez com que seu texto tratasse refugiado, não raramente, como subversivo. Esse arcaísmo da principal legislação brasileira sobre imigração obriga o CNIg a expedir, frequentemente, uma série de resoluções, que acabam se tornando nas principais diretrizes de acesso migratório no Brasil. ${ }^{21}$

A modernização da política de imigração brasileira exige, entre outras medidas, a permissão do estrangeiro de requerer visto permanente a qualquer momento, possibilitando, assim, uma via de formalização mais ágil que aquela obtida por meio de

\footnotetext{
${ }^{21}$ Países vizinhos como Argentina e o Uruguai realizaram atualização de suas leis de imigração para substituir as antigas do período ditatorial. No Brasil há um projeto de lei $\mathrm{n}^{\circ} 5655$, de autoria do poder executivo e que espera análise do poder legislativo desde 2009.
} 


\section{Conjuntura Austral}

anistia. ${ }^{22}$ É preciso, além disso, que a sociedade e a cadeia produtiva brasileira integrem o imigrante, oferecendo-lhes cursos de português e capacitação para o mercado de trabalho.

No caso da imigração haitiana, a atuação da chancelaria brasileira, em conjunto com os governos do Peru, do Equador e da Bolívia, é de suma importância para coibir a atuação de quadrilhas e dos coiotes, que exploram de forma desumana a fragilizada situação dos imigrantes.

Destaca-se, todavia, que, segundo os autores da Teoria Histórico-Estruturalista, o fluxo migratório está diretamente relacionado com o desenvolvimento do capitalismo, sobretudo com o processo de industrialização. Para Singer (1973), a principal mola propulsora dos processos de imigração são as desigualdades econômicas regionais ocasionadas pelos diferentes domínios dos processos produtivos industriais.

Depreende-se, portanto, que a política externa brasileira deve buscar angariar esforços para que haja cooperação efetiva na reconstrução do Haiti e que as promessas de doações vindas dos países desenvolvidos, principalmente após o terremoto de 2010 , materializem-se em investimentos benéficos para a melhoria socioeconômica e para o processo de estabilização política do país caribenho. É preciso eliminar os fatores de estagnação da economia haitiana. A ausência de projetos de desenvolvimento dentro do próprio Haiti constitui-se, desse modo, no maior desafio da chancelaria brasileira e da comunidade internacional, que atuam por meio da MINUSTAH, para evitar a emigração em massa dos haitianos.

\footnotetext{
${ }^{22} \mathrm{O}$ obsoleto Estatuto do Estrangeiro, concomitantemente com o grande fluxo migratório que o Brasil vem passando, fez com que o governo federal concedesse anistia em uma média de dez em dez anos. A anistia visa legalizar os imigrantes que estão de forma clandestina no território nacional. O último processo ocorreu em 2009.
} 


\section{Conjuntura Austral}

\section{REFERÊNCIAS}

CHADE, Jamil. Peru admite pressão do Brasil para pedir visto a haitianos internacional. São Paulo: $O$ Estado de S. Paulo. Disponível em: $<$ http://www.estadao.com.br/noticias/impresso,peru-admite-pressao-do-brasil-parapedir-visto-a-haitianos-,885077,0.htm>. Acesso em: 15 set. 2013.

CHAGAS, Marcos. Haitianos: governo federal libera R\$ 784 mil para ajudar governo do Acre. Brasília: Agência Brasil. Disponível em: <http://agenciabrasil.ebc.com.br/ noticia/2013-04-19/haitianos-governo-federal-libera-r-784-mil-para-ajudar-governo-doacre>. Acesso em: 15 set. 2013.

BRASIL. Agência Brasileira de Cooperação - ABC. Projetos e Acordos Haiti. Brasília: ABC. Disponível em: <http://www.abc.gov.br/download/projetos Acordos2008Haiti.pdf>. Acesso em: 23 de abr. 2012.

Agência Brasileira de Cooperação - ABC. Haiti: Cooperação para Reconstrução e Desenvolvimento. Brasília: ABC. Disponível em: <www.abc.gov.br/documentos/ViaABC12.pdf>. Acesso em 19 de jul. 2012.

Lei 9.474 de 22 de julho de 1997.

.Ministério da Justiça. Secretaria Nacional da Justiça. Brasília: Memorando no $\mathbf{9 0 7 / 2 0 1 3}$ de 30 de julho de 2013.

Ministério do Trabalho. Conselho Nacional de Imigração. Brasília: Base Estatística. Disponível em: 〈http://portal.mte.gov.br/geral/estatisticas.htm〉. Acesso em: 10 set. 2013.

Ministério do Trabalho. Conselho Nacional de Imigração. Brasília: Resolução Normativa n'97. Brasília: Diário Oficial da União. 13 de janeiro, p.59, 2012

Ministério do Trabalho. Conselho Nacional de Imigração. Brasília: Resolução Normativa n⿳102. Brasília: Diário Oficial da União. 13 de janeiro, p.96, 2013

Ministério Público Federal - Procuratória da República no Acre. Ação Civil

Pública Refugiados Haitianos. Rio Branco: MPF/AC. Disponível em: <http://www.prac.mpf.gov.br/atos-do-mpf/acp/acphaitianos/view>. Acesso em $20 \mathrm{de}$ abr.2012.

Relatório de Auditória Operacional. Sistema Nacional de Políticas sobre Drogas - Parte 1. Brasília: Tribunal de Contas da União. Disponível em: <http://portal2.tcu.gov.br/TCU>. Acesso em: 15 mai. 2013. 


\section{Conjuntura Austral}

EUA dizem que é 'absurda' acusação de golpe no Haiti. Brasília: BBC Brasil. Disponível em: <http://www.bbc.co.uk/portuguese/noticias/story/2004/03/040302_ aristidebg.shtml>. Acesso em 10 de abr.2012.

FELLET, João. Após nova regra, Brasil só concede $30 \%$ da cota de vistos a haitianos. Brasília: BBC Brasil: Disponível em: <http://www.bbc.co.uk/portuguese/ noticias/2012/02/120228_haitianos_visto_jf.shtml>. Acesso em: 15 set. 2013.

GERMANI, Gino. Sociologia da modernização: estudos teóricos, metodológicos e aplicados a América Latina. São Paulo: Mestre Jou, 1974.

GIRALDI, Renata. Saldo do terremoto no Haiti é de 220 mil mortos e 1,5 milhão de desabrigados. Brasília: Agência Brasil. Disponível em: $<$ http://agenciabrasil.ebc.com.br/noticia/2011-01-12/saldo-do-terremoto-no-haiti-e-de220-mil-mortos-e-15-milhao-de-desabrigados>. Acesso em 21 de abr. 2012.

GOMES, Joceline. Haitianos no Brasil - 1,6 mil receberam visto para trabalhar e estudar no país. Brasília: Fundação Cultural Palmares. Disponível em: <http://www.palmares.gov.br/?p=17191>. Acesso em: 22 de abr. de 2012.

GONÇALVES, Ortelinda. Migrações e Desenvolvimento. Porto: Fronteira do Caos, 2009.

LOUIDOR, Wooldy Edson. Os haitianos em Tabatinga: relato de uma peregrinação. Fortaleza: Adital - Notícias da América Latina e Caribe. Disponível em: $<$ http://www.adital.com.br/site/noticiaimp.asp?lang=PT\&img=N\&cod=59150>. Acesso em: 22 de abr. de 2012.

MELO, Daisy. Número de haitianos supera expectativa em mutirão trabalhista em Manaus. Manaus: D24AM. Disponível em: <http://www.d24am.com/noticias/ economia/numero-de-haitianos-supera-expectativa-em-mutirao-trabalhista-em-manaus/ 48717>. Acesso em 21 de abr.2012.

NAÇÕES UNIDAS. The Least Developed Countries Report 2010. United Nations Conference on Trade and Development: Genebra. Disponível em: <http://unctad.org/en/docs/ldc2010en.pdf>. Acesso em 22 de abr. 2012.

Convenção de Genebra sobre Estatuto dos refugiados. Genebra: ACNUR, 1951. Disponível em: <http://www.acnur.org/t3/portugues/recursos/ documentos/>. Acesso em: 10 de set. 2013.

Protocolo relativo ao Estatuto dos Refugiados de 1967. Genebra: ACNUR, 1967. Disponível em: <http://www.acnur.org/t3/portugues/recursos/ documentos/>. Acesso em: 10 de set. 2013. 


\section{Conjuntura Austral}

PEREIRA, Augusto Heleno Ribeiro. O Componente Militar da Missão das Nações Unidas para a Estabilização do Haiti. Military Review, edição brasileira, jan-fev, 2007, p.02-13.

Relatório Violações de Direitos Humanos em abrigo destinado a acolher haitianos na cidade de Brasiléia, norte do Brasil. São Paulo: Conectas Direitos Humanos, 2013. Disponibilidade: <http://www.conectas.org/>. Acesso em: 10 de set. 2013.

SARMIENTO, Luís Capelo. O Brasil e a MINUSTAH: As motivações e as consequências de uma operação liderada pelo Brasil. $106 \mathrm{f}$. Monografia em Ciências Sociais. Departamento de Ciências Sociais, Universidade Federal do Ceará, Fortaleza, 2010.

SINGER, P. I. Migrações internas: considerações teóricas sobre o seu estudo. In Singer P. I. Economia Política e Urbanização, Cap. 2, São Paulo: Ed. Brasiliense, 1973.

Vinda de haitianos é maior onda imigratória ao país em cem anos. São Paulo: Folha de S. Paulo. Disponível em: <http://www1.folha.uol.com.br/mundo/1033447-vinda-dehaitianos-e-maior-onda-imigratoria-ao-pais-em-cem-anos.shtml>. Acesso em: 12 de jan. 2012.

Artigo recebido dia 20 de novembro de 2012. Aprovado em 20 de setembro de 2013. 


\title{
Conjuntura Austral
}

\section{RESUMO}

$\mathrm{O}$ artigo procura analisar a recente imigração haitiana para o Brasil. O texto utiliza-se de conceitos como visto humanitário e refugio. Embasa-se em autores da Teoria Histórico-Estruturalista para compreender os fatores de atração e repulsão presente nos fluxos migratórios. O estudo, por fim, busca averiguar as ações e a estrutura político-administrativa brasileira para lidar com os imigrantes.

\section{PALAVRAS-CHAVE}

Imigração haitiana; Refugiados, Direitos Humanos.

\begin{abstract}
The article aims to analyze the recent Haitian immigration to Brazil. The text uses concepts such as humanitarian visa and refuge. The text uses as theoretical basis the authors of the History-structuralist theory to understand the factors of attraction and repulsion present in this migratory movement. The study, in the end, seeks investigate the actions and the political-administrative structure of Brazil to deal with immigrants.
\end{abstract}

\section{KEYWORDS}

Haitian Immigration, Refugees, Human Rights. 


\title{
Conjuntura Austral
}

\section{A V CÚPULA DO BRICS (DURBAN, 2013): COALIZÃO OU ARRANJO COOPERATIVO?}

\section{The V BRICS Summit (DURBAN, 2013): Coalition or \\ Cooperative Arrange?}

\author{
Leonardo Ramos ${ }^{1}$ \\ Pedro Henrique Schneider Parreiras ${ }^{2}$
}

\section{Introdução}

Desde 2001, o BRICS (Brasil, Rússia, Índia, China e África do Sul) vem ganhando cada vez mais relevância, tanto na mídia, quanto no meio acadêmico. Isto é devido, principalmente, à crescente importância dos países que compõem o grupo na economia mundial, assim como à crença de que não é possível pensar em uma governança financeira e econômica sem a presença destes países. Recentemente, o BRICS esteve mais uma vez em destaque, devido à sua última cúpula (V Cúpula) realizada em Durban, na África do Sul, ser a primeira realizada em território africano e a última do primeiro ciclo de cúpulas do BRICS ${ }^{3}$. Neste contexto, o objetivo do presente artigo é apresentar algumas das principais questões tratadas na V Cúpula do BRICS e analisar, a partir daí, seus impactos no processo de institucionalização do BRICS.

\footnotetext{
${ }^{1}$ Doutor em Relações Internacionais pela Pontifícia Universidade Católica do Rio de Janeiro. Atualmente é professor do Departamento de Relações Internacionais da Pontifícia Universidade Católica de Minas Gerais. Lidera, junto com o professor Javier Vadell, o Grupo de Pesquisa dos Países Emergentes. E-mail: lcsramos@yahoo.com.br

${ }^{2}$ Graduando em Relações Internacionais na PUC Minas. Membro do Grupo de pesquisa das Potências Médias/Middle Power Research (PUC-MG). Atualmente é bolsista de iniciação científica - PROBIC com financiamento da FAPEMIG com o projeto de conclusão de curso. E-mail: phs.parreiras@hotmail.com

3 A análise de cúpulas de países pelos seus ciclos é algo relativamente consolidado na literatura, principalmente tendo em vista as cúpulas do G7/8, por exemplo (cf., inter alia, Dobson,2007). Para os limites de tal abordagem, vide Ramos, 2013.
} 


\section{Conjuntura Austral}

Em outras palavras, a Cúpula de Durban pode ser vista como um passo na direção de uma maior institucionalização do BRICS? A hipótese é que a Cúpula de Durban indica que o grupo caminha rumo a um novo patamar de cooperação e institucionalização, sendo o banco de desenvolvimento do BRICS e o fundo comum de reserva elementos que apontariam nesta direção - sendo necessário também levar em consideração os limites de tais iniciativas. Porém, antes de prosseguir para uma análise mais detalhada da Cúpula de Durban, será feito um breve histórico do BRICS. Em seguida, será feita uma exposição da V Cúpula do BRICS, em Durban, com destaque para o banco de desenvolvimento e o fundo comum de reserva. Por fim, serão feitas algumas considerações finais sobre a questão.

\section{BRIC(S): Breve histórico}

O termo BRIC é originário de um acrônimo criado por Jim O’Neill, economista do Golden Sachs. A mesma instituição financeira, em um estudo de 2003, demonstrou que apesar de na época Brasil, Rússia, Índia e China não representarem 15\% do PIB do G6 (EUA, Grã Bretanha, Alemanha, França, Itália e Japão), os quatro países tinham potencial de igualar o PIB das seis maiores economias industriais avançadas nas próximas quatro décadas. (Armijo, 2007). Seja como for, desde a criação do acrônimo, o BRIC (posteriormente BRICS com a adesão da África do Sul), principalmente devido à China, tem aumentado a sua participação no PIB mundial, o que colocou em pauta a necessidade de reformular os organismos de governança mundial para abarcar o real peso destes países. (Jesus, 2012). Assim, o que era no início apenas um acrônimo transformou-se “(...) em um quadro diplomático para a criação de um bloco de quatro países emergentes, aparentemente dotados de vocação, sobretudo econômica, para propor alternativas ao mundo supostamente conservador do atual G7." (Almeida, 2010, p. 132).

Porém, esta transformação do BRICS ocorreu ao longo dos últimos dez anos, passando por sua primeira reunião de chanceleres em 2006, o que marcou a incorporação do termo BRIC à política externa de Brasil, Rússia, Índia e China, para finalmente incorporar a África do Sul na cúpula de Sanya em 2011, formando assim o 


\section{Conjuntura Austral}

BRICS. Após a incorporação oficial da África do Sul ao grupo, ocorreram mais duas cúpulas, a de 2012 em Nova Délhi, Índia, e a de 2013 em Durban, na África do Sul. O histórico de relações do BRICS não é marcado unicamente pela intensificação dos laços entre os países, mas também por um aprofundamento do grau de institucionalização do grupo desde da I Cúpula do BRIC, em Junho de 2009, na cidade de Ecaterimburgo, Rússia. (JESUS, 2012). Esta cúpula fora marcada pelos resultados do encontro do G20 realizada em Abril do mesmo ano. Desta forma a declaração da I Cúpula do BRIC reflete o compromisso do grupo com as decisões tomadas na cúpula do G20 e com a cooperação na próxima cúpula do fórum financeiro. Além disto, o grupo ainda sublinhou a importância de uma reforma das instituições financeiras, no intuito de aumentar a participação das economias emergentes. Por fim, em Ecaterimburgo, os países do grupo ainda deixaram claro seu compromisso com o conceito de desenvolvimento sustentável, além de declararem o avanço da cooperação do grupo em áreas como ciência e educação. (BRICS, 2009).

Por sua vez a II Cúpula do BRIC, ocorrida em Brasília, 2010, tratou de uma vasta gama de questões, mas com maior ênfase na governança global e no comércio e finanças internacionais. De maneira sucinta, a Cúpula de Brasília fora caracterizada pelo apoio do grupo à reforma da ONU, pelo pleito por uma base mais sólida para a solução da crise financeira global, pelo destaque da importância da estabilidade das principais moedas de reserva, além da defesa da solução da crise de legitimidade das organizações internacionais. (BRICS, 2010).

Já a III Cúpula, que ocorreu em Sanya no ano de 2011, tem como marco principal a entrada da África do Sul no grupo. Outro fator importante desta cúpula é o fato de que, na ocasião, os cinco países eram membros do Conselho de Segurança da ONU. Desta forma, uma maior atenção fora dada às questões de segurança, como a habitual instabilidade no Oriente Médio, e a série de revoltas no norte da África. Além da presença simultânea dos cinco membros no Conselho de Segurança, a Cúpula de Sanya fora marcada por declarações similares às das cúpulas anteriores, como o apoio às decisões tomadas no âmbito do G20 e a defesa da conclusão da Rodada Doha da OMC. (BRICS, 2011). 


\section{Conjuntura Austral}

Por fim, a IV Cúpula do BRICS, ocorrida em Nova Délhi, em 2012, apresenta um fato novo: pela primeira vez é discutida a possibilidade de criação de um banco multilateral de desenvolvimento, o que culmina no compromisso dos ministros de finanças de cada país em analisar a possibilidade de estabelecimento do banco. Além dessa questão, a declaração emitida pelo grupo reitera a importância da cooperação internacional, mas frisa a necessidade de uma reforma de organizações como o Banco Mundial e o FMI no intuito de refletir a importância das economias dos países do BRICS. (BRICS, 2012a). Outro fator importante da Cúpula de Nova Délhi é a adesão dos países do grupo a um Plano de Ação na área de cooperação agrícola, previsto para o período de 2012 - 2016. (Jesus, 2012). Feito este breve histórico, passemos agora a uma análise da Cúpula de Durban (2013).

\section{A Cúpula de Durban (2013): inovações e desafios}

Realizada em Durban, em abril de 2013, a V Cúpula do BRICS fecha o primeiro ciclo da cúpula do BRICS, além de ser um marco na árdua busca sul-africana por uma maior projeção internacional (Andreasson, 2011). Assim como as cúpulas anteriores, em Durban são reafirmados determinados elementos, como o compromisso com o multilateralismo e o apelo por uma governança global mais "democrática". Dentro do primeiro elemento destaca-se o primeiro ponto da declaração, no qual os cinco países reafirmam o seu compromisso com o direito internacional, além de reconhecerem o papel central da ONU no ambiente internacional. Ainda dentro do compromisso com o multilateralismo, os países do grupo se comprometeram a estimular os investimentos no continente africano, principalmente na infraestrutura. Com isto, o BRICS almeja "(...) auxiliar o desenvolvimento industrial, a criação de empregos, o desenvolvimento de competências, a segurança alimentar e nutricional, a erradicação da pobreza e o desenvolvimento sustentável na África.” (BRICS, 2013, §5) 4 .

Já com relação ao apelo por uma governança global mais "democrática", podemos apontar quatro pontos relevantes, sendo um deles merecedor de atenção especial. Primeiramente podemos destacar o apoio declarado a uma reforma das

\footnotetext{
${ }^{4}$ Todas as traduções são de responsabilidade dos autores.
} 


\section{Conjuntura Austral}

Instituições Financeiras Internacionais, fundamentalmente o FMI. Com esta reforma, o grupo alega desejar “(...) fazê-las mais representativas e refletir o peso crescente do BRICS e outros países em desenvolvimento.” (BRICS, 2013, §13). Este apelo se dá, principalmente, para que a reformulação das cotas acordada em 2010 seja finalmente aplicada. Destacam-se ainda o compromisso de continuar os esforços para a conclusão da Rodada Doha da OMC, o apoio a um maior papel de Brasil, Índia e África do Sul na ONU e, por fim, o apoio do grupo a um Diretor-Geral da OMC representante dos países em desenvolvimento. Tal fato é relevante uma vez que foi eleito para Diretor-Geral da OMC o brasileiro Roberto Azevêdo.

Além de tais questões, outro ponto se destacou em tal cúpula. Tendo em vista as discussões que já vinham ocorrendo desde a IV Cúpula em Nova Délhi, no ano anterior, antes mesmo da Cúpula de Durban e de sua declaração oficial, veículos midiáticos já noticiavam a possibilidade da criação de um banco de desenvolvimento do BRICS. Cinco dias antes da V Cúpula, a Reuters já noticiava que o grupo trataria da possível criação de um banco de desenvolvimento e de um fundo comum de reserva. (BRICS to endorse plans for reserves pool, development bank, 2013). Já no decorrer do encontro a BBC noticiava que o banco teria o objetivo de “(...) financiar infraestrutura e projetos de desenvolvimento nas nações em desenvolvimento." No entanto, seriam necessárias mais negociações “(...) para decidir onde seria a base do banco e quanto capital ele teria (...)." (BRICS nations discuss development bank, 2013).

A declaração final da Cúpula de Durban só confirmou o que já vinha sendo noticiado. O grupo se dispôs a criar um fundo de reserva no valor de US\$ 100 bilhões com o intuito de “(...) ajudar os países do BRICS a evitar pressões de liquidez de curto prazo, fornecer apoio mútuo e reforçar a estabilidade financeira.” (BRICS, 2013, §9). Em síntese, Guido Mantega afirmou que "O acordo de reservas nada mais é do que um grande acordo de swap entre os países (...)." (BRICS aprovam acordo de reserva de US\$ 100 bi, 2013). Com este grande acordo de swap entre os cinco países, o BRICS almeja, ao menos oficialmente, “(...) contribuir para o fortalecimento da rede de segurança financeira global e complementar os acordos internacionais existentes com uma linha adicional de defesa." (BRICS, 2013, §10) - o que acaba dando continuidade aos 


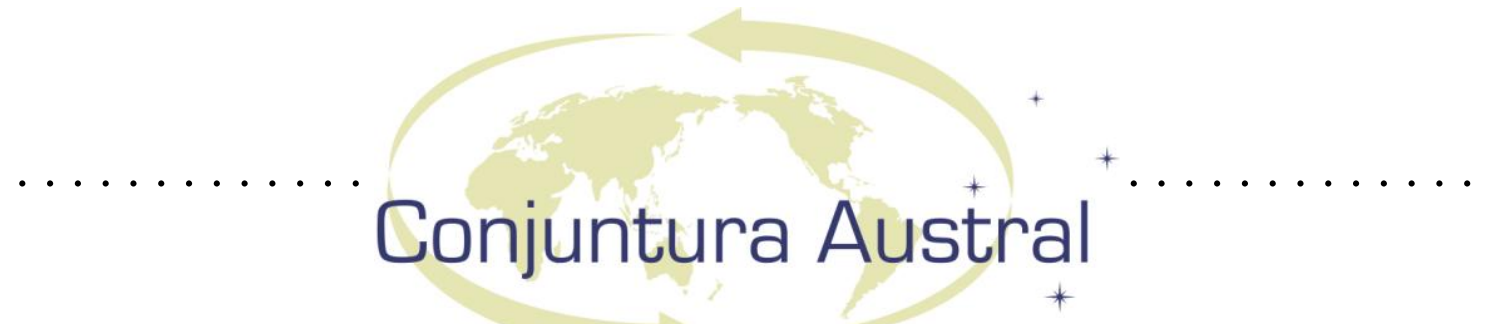

acordos que já haviam sido assinados em 2012 entre os Bancos de Desenvolvimento dos BRICS: (i) Master Agreement on Extending Credit Facility in Local Currency e (ii) BRICS Multilateral Letter of Credit Confirmation Facility Agreement, que objetivavam reduzir a demanda por moedas conversíveis para a transação entre os países dos BRICS, diminuindo assim os custos de transação no e promovendo o comércio intra BRICS (BRICS, 2012b). Além disso, neste contexto é interessante perceber que China tem mais de 20 acordos de currency swap, tendo assinado um com o Brasil logo após a cúpula do G20 em Los Cabos (Leahy, 2012).

Mas um fato extremamente relevante confirmado pela declaração final da Cúpula de Durban fora o anúncio da criação de um banco de desenvolvimento financiado pelo BRICS. Como já fora visto, na Cúpula de Nova Délhi já havia sido acordada a avaliação da possibilidade de criação de um bando de desenvolvimento do grupo. Segundo o próprio BRICS, o banco tem o objetivo de:

(...) mobilização de recursos para infraestrutura e projetos de desenvolvimento sustentável no BRICS e outras economias emergentes e países em desenvolvimento, para complementar os esforços já existentes das instituições financeiras multilaterais e regionais para o crescimento e desenvolvimento global (BRICS, 2013, §9).

Tendo recebido o respaldo de seus respectivos ministros de finanças, o grupo declarou que a criação de um banco de desenvolvimento é viável, sendo assim os BRICS concordaram em estabelecer o Novo Banco de Desenvolvimento. No entanto o montante de recursos que será disponibilizado inicialmente e a quantidade que cada país disponibilizará não ficaram claros, sendo que o BRICS limitou-se apenas a declarar o seguinte: "A contribuição inicial para o Banco deve ser substancial e suficiente para o Banco ser efetivo em financiar a infraestrutura." (BRICS, 2013, §9) ${ }^{5}$. De qualquer forma, o grupo anunciou que os progressos feitos tanto na iniciativa do fundo de reserva quanto no banco de desenvolvimento serão analisados no próximo encontro do BRICS, em Setembro de 2013.

\footnotetext{
${ }^{5}$ É importante destacar neste contexto o discurso do presidente da África do Sul, Jacob Zuma, que afirma a necessidade de que tal banco seja capaz de suprir as necessidades dos países do BRICS na área de infraestrutura, o que seria cerca de US\$4,5 trilhões nos próximos 5 anos (Zuma, 2013, p. 2).
} 


\title{
Conjuntura Austral
}

Porém não são apenas o montante de recursos e a contribuição de cada membro ao banco que permanecem nebulosos. A primeira delas diz respeito à moeda que servirá de base para as operações do banco. De acordo com um representante da África do Sul presente no encontro, os acordos já assinados em Nova Délhi poderiam servir de base mas a decisão final teria que ser tomada pelos ministros de finanças dos respectivos membros:

\begin{abstract}
Bem, como deve saber, no ano passado na cimeira de Nova Deli, assinamos um acordo, um acordo interbancário, sobre o comércio em moedas locais entre os países do BRICS. Portanto já existe um acordo sobre o comércio em moedas locais. Mas em termos de moeda de troca a ser usada pelo banco BRICS, esta é também uma questão a ser colocada aos ministros das finanças para tomarem uma decisão. (Países do BRICS vão criar um banco próprio, mas ainda não têm uma moeda referência, 2013).
\end{abstract}

Outra importante questão a ser levantada é acerca da presidência do banco. $\mathrm{O}$ cargo seria rotatório, fixo, ou teriam eleições para definir quem viria a ocupar a cadeira de presidente? Já na Cúpula de Nova Délhi, onde pela primeira vez fora debatido a possibilidade de criação do banco, esta questão já gerava debates entre os membros. No entanto não existem apenas questões funcionais acerca do banco de desenvolvimento, as diferenças já existentes no interior do grupo também podem desempenhar papel negativo na criação do Novo Banco de Desenvolvimento. As discrepâncias entre o Produto Interno Bruto (PIB) de cada país é um exemplo. Este fator poderia gerar impactos diretos no Banco de Desenvolvimento caso o sistema de aporte financeiro ao banco fosse por cotas, já que este sistema daria um papel de destaque para a China. (Jesus, 2012).

\section{Considerações finais}

Conforme apontado, uma questão de destaque na V Cúpula do BRICS se deu na área econômica - com ênfase nas discussões sobre o banco de desenvolvimento bem como na criação do fundo de reserva. Preocupações com relação ao apoio internacional para levantar recursos financeiros adicionais para o desenvolvimento e para os países em desenvolvimento não é algo novo para tais países: na verdade, tais preocupações já estavam presentes, por exemplo, em 2005, na primeira declaração do BICSAM (Brasil, 


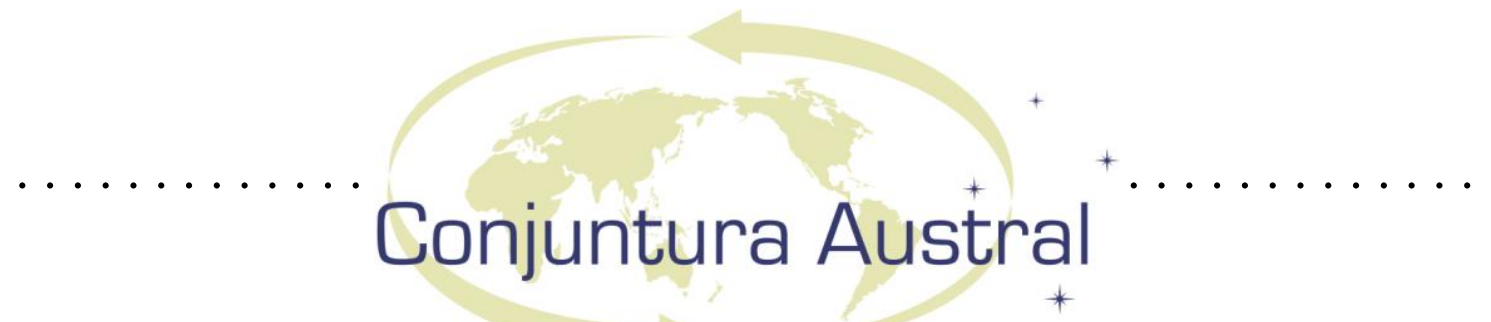

Índia, China, África do Sul e México) na cúpula de do G8 em Gleneagles (Joint declaration of the heads of state and/or government of Brazil, China, India, Mexico, and South Africa participating in the G8 Gleneagles Summit introduction, 2005).

Surge, neste ponto, uma questão: como se insere o supracitado banco de desenvolvimento neste contexto? De maneira geral, são quatro os papéis que um banco de desenvolvimento pode ter:

i. Banco de desenvolvimento - financiamento de projetos que requerem volumes de recursos maiores do que os disponíveis aos sócios; requer aporte de capital dos sócios mais ricos e captação de recursos nos mercados financeiros internacionais;

ii. Banco de desenvolvimento social - financiamento de políticas públicas e projetos de micro e pequeno porte, não requerendo capital elevado;

iii. Banco de reservas ou emprestador de emergência - garantir liquidez aos bancos centrais dos países-membros em situações de crise cambial ou financeira;

iv. Banco de compensação de pagamentos regionais - oferece liquidez para transações financeiras entre os países sócios, diminuindo a dependência destes com relação a moedas estrangeiras. Requer reservas confiáveis em moedas fortes e liquidez elevada para garantir confiança (Carvalho, et. al., 2004).

Assim, percebe-se pelas ações tomadas até então que as articulações entre os países do BRICS com relação a um banco de desenvolvimento próprio destacam o ponto iv acima. Pelas colocações feitas em Durban, há o potencial de incorporação dos pontos i e ii, mas neste ponto uma ressalva importante deve ser feita: a declaração feita pelo presidente da África do Sul (Zuma, 2013) aponta para o fato de que os recursos de tal banco de desenvolvimento deverão ser direcionados, em primeiro lugar, para certas demandas internas dos países do BRICS - ficando para um momento futuro a cooperação nesta área com outros países emergentes e em desenvolvimento ${ }^{6}$. Ora, tal afirmação é extremamente desapontadora, principalmente quando se leva em

\footnotetext{
6 “ (...) we have decided to enter formal negotiations to establish a BRICS-led new development Bank based on our own considerable infrastructure needs, which amounts to around USD 4,5 trillion over the next five years, but also to cooperate with other Emerging Markets and Developing Countries in future" (Zuma, 2013, p. 2).
} 


\section{Conjuntura Austral}

consideração (i) as discussões em torno das mudanças associadas à "ascensão do resto" (Amsden, 2009) bem como (ii) o fato da V Cúpula do BRICS ter ocorrido no continente africano e ter sido hospedada por um país africano - sem falar no Fórum de Diálogo BRICS-África que ocorreu em tal cúpula.

À luz de tais questões, é importante não perder de vista um elemento fundamental de tal iniciativa; a saber, seu papel como um elemento de pressão (i) sobre os países desenvolvidos e, em especial, sobre os Bancos de Desenvolvimento (em especial o Banco Mundial e o incômodo da África do Sul com o Banco Africano de Desenvolvimento) e o FMI, como expressão da visão dos países do BRICS de que as reformas até então acordadas são limitadas - devendo ser expandidas - e devem ser implementadas o mais rapidamente possível; e (ii) sobre os países desenvolvidos (e em especial sobre os Estado Unidos), no âmbito G20, para avanços no que diz respeito às reformas no sistema monetário internacional.

De qualquer forma, tanto o fundo de reserva quanto o banco de desenvolvimento apontam para uma maior institucionalização do BRICS. No entanto, talvez fosse mais prudente falar no início de uma transição de uma coalizão entre os países que compõem o BRICS, para um arranjo cooperativo entre os países que compõem o mesmo grupo. Segundo Lima (2007), o “(...) arranjo cooperativo envolve a troca entre as partes de bens materiais, simbólicos e ideacionais. Uma coalizão implica na articulação de posições comuns em arenas de negociação no plano global ou regional.” (Lima, 2007, p. 164). Desta forma, o BRICS, que começou, segundo Lima (2013), como uma coalizão para a atuação comum na arena financeira global, começa a gerar indícios de que pode vir a ser um arranjo cooperativo no futuro.

Não obstante, não se deve exagerar em tais questões: como visto, várias questões procedimentais fundamentais concernentes ao banco de desenvolvimento ainda não foram resolvidas, e o fundo de reserva criado com um aporte inicial de US\$100 bilhões, embora importante, apresenta cifras significativamente modestas quando comparado, por exemplo, ao montante mobilizado por vários países (incluindo os países do BRICS) para o FMI (cerca de meio trilhão de dólares), aos fundos levantados recentemente pela União Européia ou a Iniciativa Chiang Mai,por exemplo (Kirton, Bracht \& Kulik, 


\section{Conjuntura Austral}

2013). Assim, a despeito da Cúpula de Durban apontar para um novo estágio na cooperação entre os BRICS, a criação da primeira instituição do grupo só poderá ser atestada no decorrer dos próximos encontros entre os cinco países.

\section{REFERÊNCIAS}

ALMEIDA, Paulo Roberto. O BRIC e a substituição de hegemonias. In: BAUMANN, Renato (org.). O Brasil e os Demais BRICs: Comércio e Política. Brasília, CEPAL, 2010.

AMSDEN, Alice H. A ascensão do "resto": Os desafios ao ocidente de economias com industrialização tardia. São Paulo: UNESP, 2009.

ANDREASSON, Stefan. Africa's prospects and South Africa's leadership potential in the emerging markets century. In: Third world quarterly, 32 (6), p. 1165-1181, 2011.

ARMIJO, Leslie Elliott. The Brics countries (Brazil, Russia, India, and China) as analytical category: mirage or Insight?. In: Asian Perspective, 31 (4), p. 7-42, 2007.

'Banco dos BRICS' não deverá sair antes de 2016. Folha de São Paulo, 26/03/2013. Disponível em: <http://www1.folha.uol.com.br/mundo/1252448-banco-dos-brics-naodevera-sair-antes-de-2016.shtml>. Acessado em: 04/07/2013.

BRICS. First Summit, 2009. Disponível em: <http://www.brics5.co.za/aboutbrics/summit-declaration/first-summit/>. Acessado em: 02/07/2013.

BRICS. Second Summit, 2010. Disponível em: <http://www.brics5.co.za/aboutbrics/summit-declaration/second-summit/>. Acessado em: 02/07/2013.

BRICS. Third Summit, 2011. Disponível em: <http://www.brics5.co.za/aboutbrics/summit-declaration/third-summit/>. Acessado em: 02/07/2013.

BRICS. Fourth Summit, 2012a. Disponível em: <http://www.brics5.co.za/aboutbrics/summit-declaration/fourth-summit/>. Acessado em: 02/07/2013. 


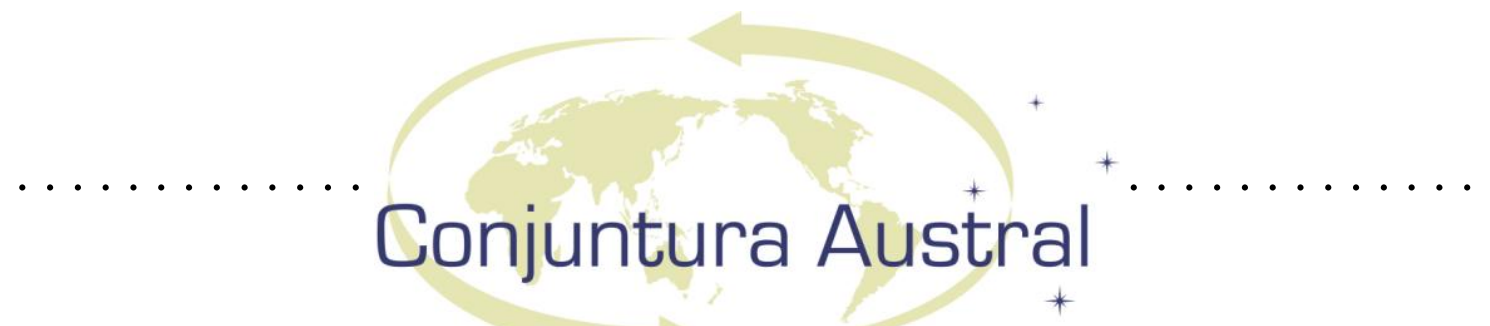

BRICS. Agreements between BRICS Develoment Banks. Nova Délhi, 29/03/2012b. Disponível em: <http://www.brics.utoronto.ca/docs/120329-devbank-agreement.html>. Acessado em: 06/08/2013.

BRICS. Fifth Summit, 2013. Disponível em: <http://www.brics5.co.za/aboutbrics/summit-declaration/fifth-summit/>. Acessado em: 02/07/2013.

BRICS aprovam acordo de reserva de US\$ 100 bi. Diário do Grande ABC, 26/03/2013. Disponível em: <http://www.dgabc.com.br/Noticia/94316/brics-aprovamacordo-de-reserva-de-uss-100-bi > . Acessado em: 04/07/2013.

BRICS nations discuss development bank. BBC, 27/03/2013. Disponível em: <http://www.bbc.co.uk/news/business-21951160>. Acessado em: 03/07/2013.

BRICS to endorse plans for reserves pool, development bank. Reuters, 21/03/2013. Disponível em: <http://www.reuters.com/article/2013/03/21/brics-bankidUSL1N0CD5TD20130321>. Acessado em: 03/07/2013.

CARVALHO, Carlos Eduardo, et. al. Banco do Sul: A proposta, o contexto, as interrogações e os desafios. In: VADELL, Javier A. \& LAS CASAS, Taiane (orgs.). Os novos rumos do regionalismo e as alternativas políticas na América do Sul. Belo Horizonte: Ed. PUC Minas, 2011.

DOBSON, Hugo. The group of G7/8. London: Routldge, 2007.

JESUS, Diego Santos Vieira de. De Nova Iorque a Nova Délhi: Informalidade, Flexibilidade e Independência no BRICS. In: NOGUEIRA, João Pontes (org.). Os BRICS e as Transformações na Ordem Mundial. Rio de Janeiro: PUC-Rio. 2012.

Joint declaration of the heads of state and/or government of Brazil, China, India, Mexico, and South Africa participating in the G8 Gleneagles Summit introduction. 07/07/2005. Disponível em: <http://www.g8.utoronto.ca/summit/2005gleneagles/ index.html>. Acessado em: 02/08/2013.

KIRTON, John; BRACHT, Caroline \& KULIK, Julia. A Productive and Promising Performance: The 2013 BRICS Durban Summit. 27/03/2012. Disponível em: $<$ http://www.brics.utoronto.ca/analysis/durban-performance.html>. Acessado em: 02/08/2013.

LEAHY, Joe. Brazil and China agree currency swap. In: Financial Times, 22/06/2012. Disponível em: <http://www.ft.com/cms/s/0/015f526a-bc07-11e1-9aff00144feabdc0.html\#axzz2V3OF5oul>. Acessado em: 15/09/2012. 


\section{Conjuntura Austral}

LIMA, Maria Regina Soares de. Brasil e pólos emergentes do poder mundial: Rússia, Índia, China e África do Sul. In: BAUMANN, Renato (org.). O Brasil e os Demais BRICs: Comércio e Política. Brasília: CEPAL, 2010.

Novo banco e fundo de reserva fortalecem articulação do BRICS. BBC Brasil, 27/03/2013. Disponível em: <http://www.bbc.co.uk/portuguese/noticias/2013/03/130326_brics_dilma_rc.shtml>. Acessado em: 04/07/2013.

Países do BRICS vão criar um banco próprio, mas ainda não têm uma moeda referência. Voz da América, 22/03/2013. Disponível em: <http://m. voaportugues.com/a/1626676.html>. Acessado em: 04/07/2013.

PATRICK, Stewart. Irresponsible stakeholders? The difficulty of integrating rising powers. In: Foreign affairs, 89 (6), p. 44, Academic OneFile, 2010.

RAMOS, Leonardo César Souza. Hegemonia, revolução passiva e globalização: O sistema G7/8. Belo Horizonte: PUC Minas, 2013.

ZUMA, Jacob. Addressing the summit theme "BRICS and Africa: partnership for development, integration and industrialisation". 27/03/2013. Disponível em: $<$ http://www.brics5.co.za/plenery-session-statement-by-the-honourable-president-ofthe-republic-of-south-africa-his-excellency-jacob-zuma/>. Acessado em: 02/08/2013.

Artigo recebido dia 08 de agosto de 2013. Aprovado em 20 de outubro de 2013. 


\title{
Conjuntura Austral
}

\section{RESUMO}

$\mathrm{O}$ artigo busca apresentar algumas das principais questões tratadas na V Cúpula do BRICS e analisar, a partir daí, seus impactos no processo de institucionalização do BRICS. A hipótese é que a Cúpula de Durban indica que o grupo caminha rumo a um novo patamar de cooperação e institucionalização, sendo o banco de desenvolvimento do BRICS e o fundo comum de reserva elementos que apontariam nesta direção - sendo necessário também levar em consideração os limites de tais iniciativas.

\section{PALAVRAS-CHAVE}

BRICS; Institucionalização; Cooperação; Banco de desenvolvimento.

\begin{abstract}
This paper aims to show some of the main questions that were discussed in the $\mathrm{V}$ BRICS Summit and analyze, from there, their impact on the process of institutionalization of the BRICS. The hypothesis is that the Durban Summit indicates that the group is moving towards a new level of cooperation and institutionalization, and the Development Bank of the BRICS and common reserve fund elements that would point in this direction - it is also necessary to take into account the limits of such initiatives.
\end{abstract}

\section{KEYWORDS}

BRICS; Institutionalization; Cooperation; Development Bank. 
RESENHA

Bookreview

\title{
MILITARY POWER: EXPLAINING VICTORY AND DEFEAT IN MODERN BATTLE ${ }^{1}$
}

\author{
Tamiris Pereira dos Santos ${ }^{2}$
}

Por que ganhadores vencem e perdedores perdem? O que define a vitória ou a derrota no campo de batalha? Seriam os avanços tecnológicos as únicas variáveis a serem consideradas no processo de modernização da Guerra? Estas são as questões norteadoras para o desenvolvimento do livro de Stephen Biddle Military Power: Explaining Victory and Defeat in Modern Battle.

Tecendo críticas acerca da ênfase conferida ao emprego da tecnologia na Guerra - considerado como Revolução nos Assuntos Militares (Revolution in Military Affairs RMA) por autores como O'Hanlon ${ }^{3}$ - Biddle constrói seus argumentos tendo como cerne explicativo que variáveis não materiais, como o emprego da força, doutrina ou tática submetidas no combate também possuem centralidade na predeterminação entre ganhadores e perdedores. Logo, a compreensão entre a interação entre variáveis materiais e não materiais se faz um elemento chave para captar as considerações de Biddle, as quais indicam que apesar da inexorabilidade de mudanças advindas de avanços tecnológicos, existem elementos de continuidade nos combates, os quais não devem ser suprimidos pela superênfase dada aos primeiros.

\footnotetext{
1 BIDDLE, Stephen M. Military Power: Explaining Victory and Defeat in Modern Battle. Princeton: Princeton University Press, 2006, 352p. ISBN: 10: 0-691-12802-2.

${ }^{2}$ Mestre em Ciências da América Latina pela Universidade de São Paulo (USP). Doutoranda em Estudos Estratégicos Internacionais pela Universidade Federal do Rio Grande do Sul (UFRGS). Email: tpsantos88@gmail.com.

3 O'HANLON, Michael E. The Science of War. New Jersey: Princeton University Press, 2009.
} 


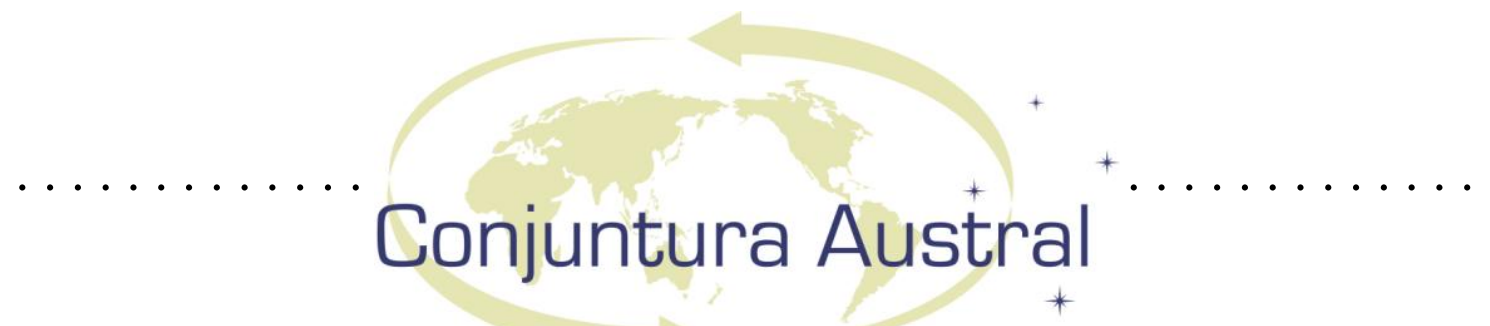

Com uma metodologia que agrega breves revisões historiográficas, considerações teóricas compreendendo visões críticas acerca da visão unitarista do Estado e do que o autor considera como uma fraca base empírica reduzida ao conceito de capacidades ${ }^{4}$, e, por fim, exploração de operações, apresentação de dados empíricos e experiências com simulações usando dados do Departamento de Defesa dos EUA (DoD - Department of Defense). Explicitações acerca do que vem a ser poder militar, a escolha por adotar as terminologias capacidade militar ofensiva e defensiva, bem como demarcações metodológicas e notas sobre os próximos capítulos compõem o capítulo introdutório do livro.

O segundo capítulo se estrutura basicamente em três partes: apresentação de concepções difundidas academicamente (preponderância numérica, tecnologia e emprego da força); confrontação destas formulações com dados empíricos, encerrando com uma análise crítica. Com este movimento, Biddle tenta demonstrar a insuficiência explicativa no âmbito da teoria em seus esforços para delimitar o conceito de capacidade, trazendo à baila a demanda por uma nova variável explicativa - a saber, o emprego da força - a fim de formalizar uma compreensão acerca de capacidade que não contemple apenas preponderância e tecnologia.

Neste sentido o terceiro capítulo propõe um delinear do emprego da força no âmbito do que o autor intitula como Sistema Moderno ${ }^{5}$ a partir de quatro etapas: 1) revisão das mudanças tecnológicas ocorridas ao final do século XIX, as quais tornaram o poder de fogo como questão central para operações e táticas a posteriori; 2) breve estudo das alternativas provenientes do Ocidente para a questão do poder de fogo ao

\footnotetext{
${ }^{4}$ Crítica direcionada à formulação teórica de Waltz (1979), o realismo estrutural, apresentado em Theory of International Politics.

${ }^{5}$ Conforme considerações do autor ao longo do capítulo, o Sistema Moderno seria um arranjo baseado na organização tática em batalha, contendo elementos para táticas ofensivas e defensivas; os elementos principais das táticas ofensivas seriam: abrigo, encobrimento, dispersão, manobras independentes de unidades pequenas, supressão, integração de forças combinadas e limitação de alvos, a fim de destruir posições defensivas inimigas mesmo ante o fogo pesado; os elementos nas táticas defensivas seriam: profundidade, reservas e contra-ataque. Neste sentido, a efetividade do sistema habita muito na habilidade das tropas em aplicar tais táticas, questão discutida pelo autor ao fim do capítulo mencionado, quando o autor pondera que fatores de origem política, cultural e organizacional tiram os Estados da rota de adoção de doutrinas militares baseadas no Sistema moderno, sendo que o peso destes fatores varia de Estado para Estado (BIDDLE, 2006).
} 


\section{Conjuntura Austral}

longo da Primeira Guerra Mundial, apresentando como estas orquestraram uma espécie de padrão, intitulado pelo autor como o sistema moderno de emprego da força; 3 ) demonstração do funcionamento do Sistema Moderno e como este possibilitou a resistência das Forças Armadas ao crescente potencial do poder de fogo; 4) balanço das dificuldades organizacionais e políticas em se implementar o Sistema Moderno - as variações no emprego da força e as dificuldades organizacionais e políticas dos Estados.

O quarto capítulo, também disposto em quatro partes, se destina a demonstrar de forma comparativa as mudanças tecnológicas e em que grau estas afetaram a aplicação do Sistema Moderno, apresentando tendências para o futuro e considerações da aplicação teórica proposta. Rememorando os casos da Guerra do Afeganistão e em Kosovo, o autor explicita que o emprego da tecnologia para o avanço do poder de fogo e da letalidade aumentaram a significância do Sistema Moderno e suas estratégias, revelando que os elementos que compõem as táticas ofensivas e defensivas deste modelo não foram mitigados pelos avanços tecnológicos através de demonstrações gráficas, negando a abordagem da preponderância numérica em combate e comparando efeitos em no Sistema Moderno e "não moderno".

Após dois capítulos com esforços de demarcação teórica em meio a concepções às quais Biddle se posiciona criticamente, os três capítulos subsequentes (quinto, sexto e sétimo) lidam diretamente com análises das Operações Michael (2 $2^{\mathrm{a}}$ Batalha do Somme, França - 21/03 a 9/04/1918), Goodwood (Região da Normândia - 18 a 20/07/1944) e Desert Storm (Golfo Pérsico - 17/01 a 28/02/1991), estruturando-se em justificativa de análise para as Operações mencionadas, apresentação de variáveis independentes, táticas ofensivas e defensivas, e um balanço geral contemplando pontos de convergência e divergência com a proposta teórica do Sistema Moderno, além de implicações.

Após um delinear com estudos de caso, Biddle inclui de forma mais expressiva, ao longo do oitavo capítulo, as componentes empíricas para analisar o Sistema Moderno ou "Nova Teoria", apresentando dados da Michigan's Correlates of War (COW), de um banco de dados das Forças Armadas dos EUA intitulado $\mathrm{CDB}^{6}{ }^{6}$, bem como uma compilação de dados acerca de sofisticação tecnológica em dezesseis situações de pós-

\footnotetext{
${ }^{6}$ Referente as 660 batalhas que tiveram lugar entre 1600 e 1982 (BIDDLE, 2006).
} 


\section{Conjuntura Austral}

guerra no período de 1956 a 1992, denominada pelo autor de MILTECH. A manobra apresentada neste capítulo, além de aferir um conteúdo estatístico, foi a de comparar a Nova Teoria com as formulações ortodoxas, resgatando as concepções difundidas academicamente $^{7}$ para inseri-las em diversas hipóteses. Estas, por sua vez, compreendem como parâmetros a análise da preponderância numérica em relação de forças terrestres (FFR - Force-to-Force Ratio), força terrestre e força espacial (FSR Force-to-Space Ratio), tecnologia de forma sistêmica e de forma dual, no âmbito das baixas militares, ganho territorial e duração. Finalizado o "teste" empírico a fim de validar a Nova Teoria, Biddle procede às experimentações com a simulação em computadores ao nono e penúltimo capítulo, esclarecendo que os modelos não pressupõem teorias de combate, mas ferramentas para análise teórica no âmbito previamente demarcado pelo autor.

No último capítulo, dedicado à conclusão, Biddle retoma os questionamentos previamente tratados, relacionados à proposição de capacidade, emprego da força e a limitação da componente material como determinante para o lado vitorioso, estruturando a seguir o capítulo em partes: implicações da Nova Teoria para a academia, contemplando críticas para as visões difundidas negadas à vista de sua formulação teórica, bem como recomendações, e implicações para a política.

Revisando considerações acerca da Nova Teoria, o autor demonstra como esta formulação privilegia a visão do conceito de capacidade de forma abrangente e multidimensional, a fim de contemplar de forma menos estreita a referida questão no âmbito militar - comparando a forma como as Relações Internacionais lidam com a temática. Quanto às considerações da Nova Teoria para o âmbito da política, o autor desenvolve seis pontos que considera principais enquanto concernentes ao futuro da guerra: as prioridades do orçamento de defesa, estrutura da força, desenvolvimento e aquisição de armamentos, avaliação da campanha conjunta e a doutrina militar. Apesar de considerar todos os referidos pontos, as principais críticas do autor ao longo da apresentação da Nova Teoria repousaram em prover uma visão alternativa para a supervalorização do âmbito material e tecnológico da guerra, superdimensionando estas

\footnotetext{
${ }^{7}$ Objeto de análise sucinta ao segundo capítulo do livro.
} 


\section{Conjuntura Austral}

componentes no âmbito da RMA e negligenciando o desdobramento da capacidade como questão não material, através do componente tático por exemplo.

Portanto, o trabalho de Biddle visa contribuir para uma ampliação dos horizontes de estudos da guerra para além da estratégia do unitarismo, presente em algumas formulações teóricas específicas nas RI, e para além do exacerbado entusiasmo demonstrado por estudiosos que advogam a tecnologia como condição sine qua non para a obtenção de vitórias nas batalhas face ao fenômeno do RMA, fornecendo parâmetros de contraponto interessantes para o desenvolvimento de estudos que tenham a multidimensionalidade como pressuposto.

Resenha recebida dia 10 de março de 2013. Aprovado em 20 de agosto de 2013. 


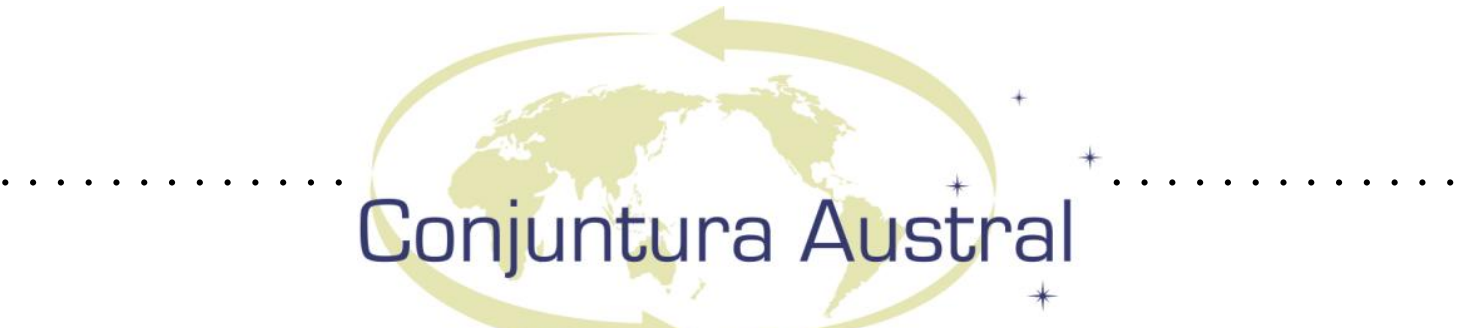

NORMAS DE SUBMISSÃO / Submission Standards

\section{Diretrizes para Autores}

1. A revista CONJUNTURA AUSTRAL publica artigos científicos e resenhas bibliográficas;

2. A revista está dividida em três seções: Conjuntura; Pesquisa e Leitura (resenhas)

3. Os artigos de análise de conjuntura devem conter entre 8 mil e 12 mil caracteres (incluindo espaços) e os artigos de pesquisa devem conter cerca de 25 mil caracteres, as resenhas bibliográficas devem conter cerca de 3 mil caracteres (espaços inclusive);

4. As notas de rodapé restringem-se a esclarecimentos adicionais ao texto;

5. A bibliografia deve ser citada de acordo com o sistema Chicago (Autor, data), referenciando a literatura citada ao final do texto;

6. As contribuições devem ser inéditas e podem ser submetidas em português, inglês ou espanhol;

7. As contribuições devem conter o nome completo do autor, sua titulação e filiação institucional;

8. Admite-se a publicação de estudantes de graduação, desde que em parceria com um professor orientador titulado, que constará como autor principal do trabalho.

9. No caso de resenhas bibliográficas, devem ser informados os dados completos e o ISBN da obra analisada;

10. As contribuições devem vir acompanhadas de: 3 palavras-chave em português e 3 key words em inglês; Título em inglês; Resumo em português e Abstract em inglês, ambos com até 50 palavras.

11. Todas as submissões devem ser feitas através do site da revista : www.seer.ufrgs.br/ConjunturaAustral.

\section{Condições para submissão}

Como parte do processo de submissão, os autores são obrigados a verificar a conformidade da submissão em relação a todos os itens listados a seguir. As submissões que não estiverem de acordo com as normas serão devolvidas aos autores.

1. A contribuição é original e inédita, e não está sendo avaliada para publicação por outra revista; caso contrário, deve-se justificar em "Comentários ao Editor".

2. Os arquivos para submissão estão em formato Microsoft Word, OpenOffice ou RTF (desde que não ultrapassem 2MB)

3. URLs para as referências foram informadas quando necessário.

4. O texto está em espaço simples; usa uma fonte Times New Roman de 12-pontos; emprega itálico em vez de sublinhado (exceto em endereços URL); as figuras e tabelas estão inseridas no texto, não no final do documento, como anexos.

5. O texto segue os padrões de estilo e requisitos bibliográficos descritos em Diretrizes para Autores, na seção Sobre a Revista, no site www.seer.ufrgs.br/ConjunturaAustral.

6. A identificação de autoria do trabalho foi removida do arquivo e da opção Propriedades no Word, garantindo desta forma o critério de sigilo da revista, caso submetido para avaliação por pares (ex.: artigos), conforme instruções disponíveis em Assegurando a Avaliação Cega por Pares.

\section{Author Guidelines}

1. The journal CONJUNTURA AUSTRAL publishes articles and book reviews;

2. The journal is divided in three sections: Conjuncture (Conjuntura), Research (Pesquisa) and Review (Leitura);

3. The conjuncture analysis articles must contain a minimum of 8 thousand and a maximum of 12 thousand characters (spaces included) and the research articles must contain around 25 thousand characters; the book reviews must contain around 3 thousand characters (spaces included);

4. The footnotes should be strictly of a substantive and complementary nature;

5. The bibliography must follow the rules of the Chicago system (Author, date), specifying the used literature at the end of the text;

6. Contributions must be original and can be submitted in Portuguese, English or Spanish;

7. Contributions must contain the full name of the author, their titles and institutional affiliation;

8. Publications of undergraduate students are accepted, as long as in partnership with an advisor professor, which will appear as the main author of the work;

9. Book reviews must contain the complete data and the ISBN of the analyzed work;

10. Contributions must be accompanied of: 3 key-words in Portuguese and 3 key-words in English; Title in English; Abstract in Portuguese, Abstract in English, both with up to 50 words.

11. All the submissions should be made through the website: www.seer.ufrgs.br/ConjunturaAustral.

\section{Submission Preparation Checklist}

As part of the submission process, authors are required to check off their submission's compliance with all of the following items, and submissions may be returned to authors that do not adhere to these guidelines.

1. Contributions must be original, and shall not have been submitted for publication in another journal; otherwise, it must be justified in "Comments to the Editor".

2. Submitted files must be in Microsoft Word, OpenOffice or RTF (as long as their size is up to 2MB) format.

3. URLs must be informed in the references when necessary.

4. The text must be single-spaced; Times New Roman typeface 12 pt must be used for the body of the text; italic is to be used instead of underline (except in URL addresses); Figures and Tables must be embedded in the text.

5. The text must follow patterns of style and bibliographical requirements described in Authors Guidelines Author Guidelines, in the section "About the Journal", on the website: www.seer.ufrgs.br/ConjunturaAustral.

The identification of authorship of the work must be removed from the file and the Properties option in Word, thus ensuring the confidentiality criteria of the journal, if it is to be subjected to peer review (i.e. articles), accordingly with available instructions in "Ensuring Blind Peer Review". 


\section{Conjuntura Austral}

\section{INDEXADORES}

Os artigos publicados na Revista Conjuntura Austral estão sumarizados e indexados nos seguintes serviçoes internacionais (Articles appearing in this journal are abstracted and indexed in the following international services):

- Latindex

- Google Scholar

- Portal de Periódicos UFRGS

- Citas Latinoamericanas en Ciencias Sociales y Humanidades (CLASE) 